
\title{
$\underset{236}{\mathrm{HB}}$ \\ $\mathrm{U}_{5} \mathrm{~B}_{3}$
}
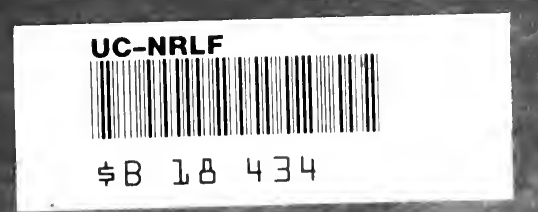


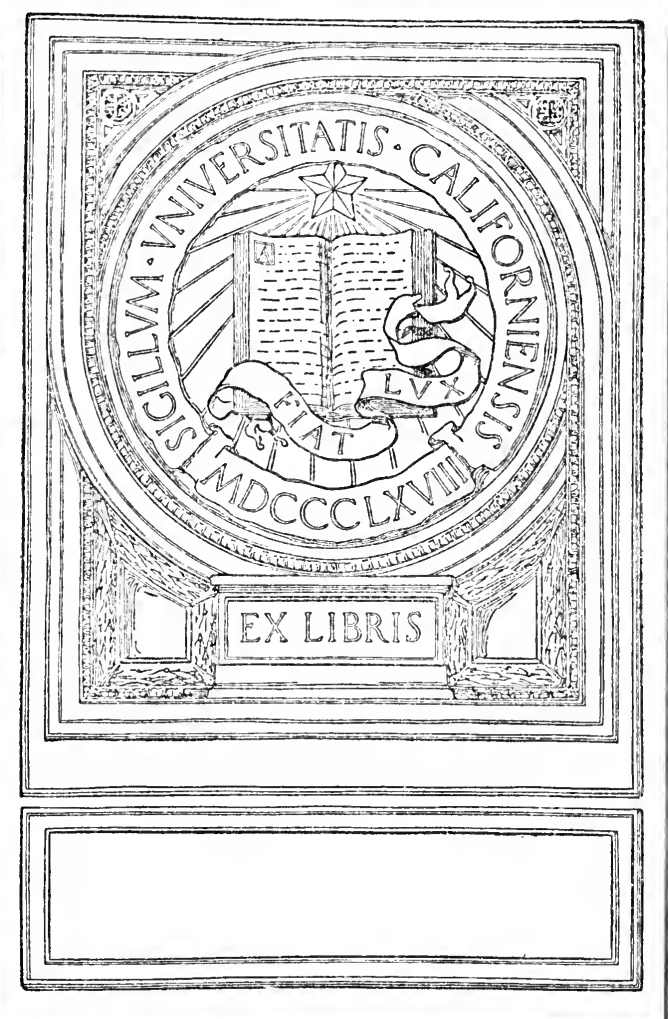




\section{A Study of Price Control by the United States Food Administration}

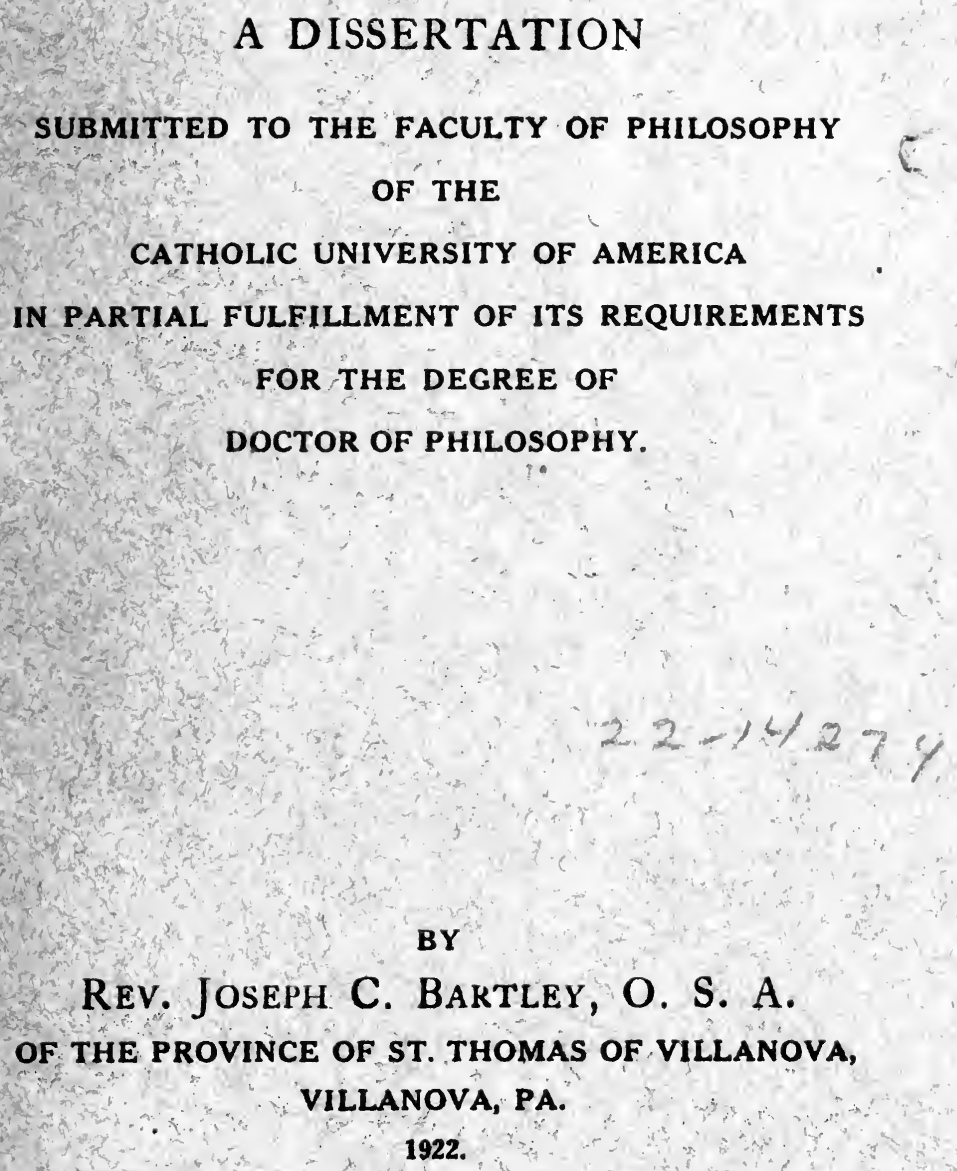

BY

ReV. Joseph C. BakTley, O. S. A. OF THE PROVINCE OF ST. THOMAS OF VILLANOVA, VILLANOVA, PA. 1922. 


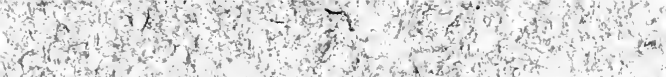

$\int^{2}$

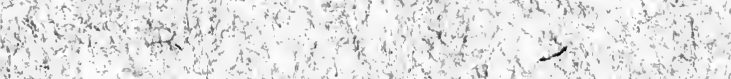
Whithes 4 in 1
$x+4$
4
+
+4

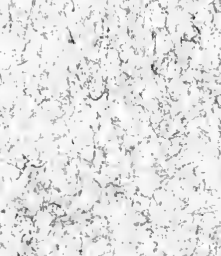

:

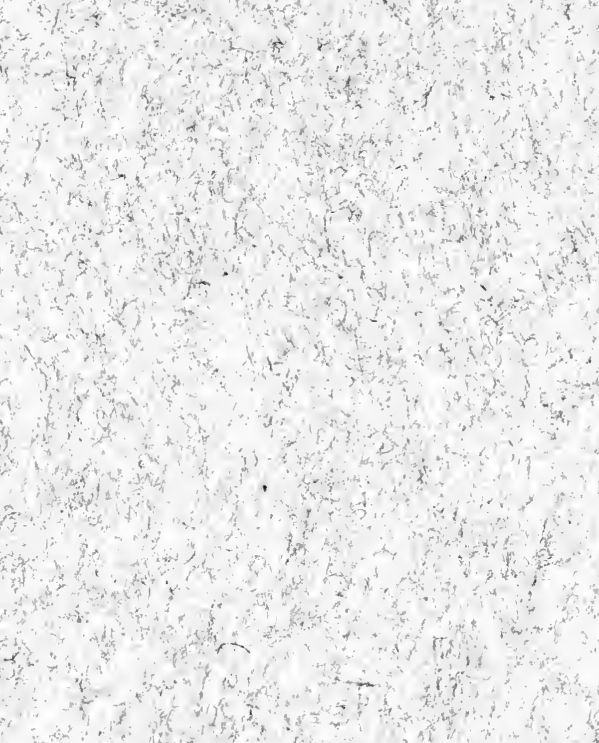

to

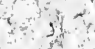

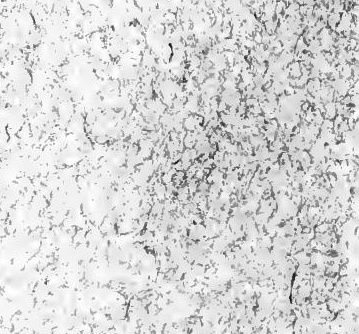

A

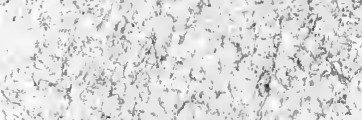

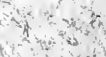

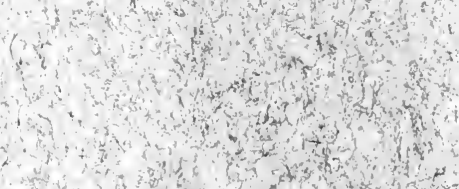

$4-3 \cdot-4$

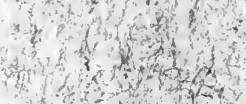

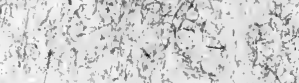

- mats $4 x+310 y$ $y$ ont

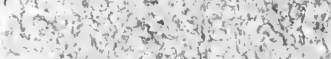
$4 c^{4}+1$ 


\title{
A Study of Price Control by the United States Food Administration
}

\author{
A DISSERTATION \\ SUBMITTED TO THE FACULTY OF PHILOSOPHY \\ OF THE \\ CATHOLIC UNIVERSITY OF AMERICA \\ IN PARTIAL FULFILLMENT OF ITS REQUIREMENTS \\ FOR THE DEGREE OF \\ DOCTOR OF PHILOSOPHY.
}

BY

Rev. Joseph C. Bartley, O. S. A. OF THE PROVINCE OF ST. THOMAS OF VILLANOVA, VILLANOVA, PA. 1922. 
$\mathrm{HB} 236$

$45 B 3$ 


\section{TABLE OF CONTENTS.}

I Preface $\ldots \ldots \ldots \ldots \ldots \ldots \ldots \ldots \ldots \ldots$ 5

II Price Control and Price-Fixing $\ldots \ldots \ldots \ldots$ ?

III Beginnings of Government Control ....... 16

IV Control of Wheat, Flour and Bread ....... 34

V Control of Sugar .................. 56

VI Control of Meat and Dairy Products ....... 75

VII Control of Canned Goods .................100

VIII Control of the Unlicensed Retailer ..........109

IX Conclusion .......................114

$\mathrm{X}$ Appendix-Early Attempts at Price-Fixing..123

XI Bibliography .....................136 
Digitized by the Internet Archive in 2007 with funding from Microsoft Corporation 


\section{PREFACE.}

The United States Food Administration, during its brief war time existence became almost an international organization. As the breakdown of European food production became more and more imminent, ever increasing dependence was placed upon American markets. With each of the Allies striving to secure large allotments of foodstuffs from us, the necessity of some organization to apportion amounts according to needs became imperitive. Never before was there greater need of handling food problems from an international viewpoint. Thus, in accordance with this necessity was the United States Food Administration forced to adopt policies of wider scope than those whose aim was the provision of national needs.

In this country, the Food Administration's influence was everywhere felt. It dealt with problems that arose unbidden, but which affected vitally the nation at large and every individual who composed it. The worker in the factory, the man in the office, the soldier on the battle-field; producer, manufacturer and consumer all came within the scope of its jurisdiction and were affected more or less by its regulations and requirements. The work of this organization, the problems that it had to cope with, and the manner in which they were solved, although now stripped of their war-time importance, have their lesson to teach.

The aim of this study is to present an historical account of the work of the United States Food Administration from an economic view-point. No attempt is made to give a complete account. When it is considered that over 300 separate commodities came under control, the size of such a task can be appreciated. Of the control of many of these commodities scarcely any written record exists. The real work of the Food Administration was 
centered upon a few basic commodities. Of these we have made a detailed study in this work.

Since this study was begun, several War Industries Bulletins have appeared. Special mention must be given to Bulletin No. 3, entitled "Government Control Over Prices," which the writer has used frequently as a guide in following the thread of a sometimes hazy narrative. Care has been taken to examine its view-point and to supply what are, perhaps, intentional omissions.

In the appendix will be found a brief account of several of the most important attempts to fix prices in times past. It is hoped that this material will be of value because of the comparison it affords between past and present experiences with governmental control over prices.

The writer wishes to express his deep appreciation for the valuable suggestions and the timely encouragement needed in completing this task to his major professor. Dr. Frank O'Hara. 


\section{CHAPTER I.}

\section{PRICE CONTROL AND PRICE-FIXING.}

The extension of governmental supervision over many of the phases of private initiative has brought to light a number of terms all of which serve to indicate the general idea of control. We are now fairly familiar with such terms as regulation, supervision, nationalization, rationing, price-fixing and price-control. It is chiefly with the last named term that we shall deal in this work.

Control is a word of wide meaning. In general it implies a check or restraint placed upon a weaker organism, by a more powerful one. As exercised by the Government in an economic sense, control may indicate any degree of supervision ranging from the enforcement of a slight regulation to the actual handling of a business itself. If some effort is made by government authority to check prices from increasing abnormally, such an effort might be termed price control.

Our government's experience with prices during the war was largely an experience of price control, rather than of price fixing. Prices are fixed when an expressed amount of a commodity and no less must sell for an expressed amount of money and no.more. Many of the European nations adopted this direct method of controlling prices; the United States, however, in deference to the traditional freedom of economic pursuit expressed itself at the outset at least, as opposed to a system of direct price-fixing. It was thought much more could be accomplished by enlisting the voluntary cooperation of producers, manufacturers and consumers. In the beginning of our war time experience with price control, therefore much emphasis was placed upon the patriotic appeal, but as the hand of the government agencies tightened their grip upon business and industry, it be- 
came evident that more reliance should be placed upon punishments and penalties and less upon the uncertain factor of voluntary agreements. With this change in the character of control, the Food Administration tended to adopt more definite measures of regulating prices: yet these measures never reached the stage of direct pricefixing.

Rationing $^{1}$ though often used in conjunction with price-fixing may be considered apart from it. In fact, a system of rationing may be established without any attempt to fix a price. Rationing means that a certain amount of a commodity is alloted to an individual, a family, or a group during a definite period of time. In this case, the government is more concerned with the distribution of the commodity than with its price. The entire supply of the commodity may be then purchased or commandeered by authority to be distributed according to a pro-rata plan. The distribution of the article itself, however, may be made through the ordinary channels of trade such as brokers, wholesalers and retailers. While price-fixing or price-control is difficult to enforce, a system of rationing may be established with well-nigh complete success. With its hands upon the total available supply of a commodity, a government may ration its people with almost the same ease as it pays off its employees. Control of this kind, however, presupposes, production. The main difficulty to be met with in any system of control is with production itself.

There are no possible means of making a man produce if he does not wish to. Pains and punishments may stimulate to some degree, but fundamentally the individual is free to produce or not to produce. Patent as this truth is, many governments have endeavored to establish control without taking it into consideration. In the end failure and famine have resulted.

Although theoretically control can be established without any reference to price, practically the price element

I In the United States the stage of rationing was never fully reached; yet some attempt was made to ration sugar, and flour. 
plays a large role. It is to price that the farmer and the manufacturer pays the most attention. If the farmer is assured of a reasonable price for his produce, and the manufacturer a fair margin for his output, production will not be curtailed and rationing the consumer becomes practical as far as production is concerned.

A government may extend control to the rationing of its manufacturers, tradesmen and people. When the demand for necessities greatly exceeds the available supply, distribution of these necessities is limited only to those who can afford to pay excessive prices.

At this point it should be recalled that commodity usually passes through three main stages. It is produced, then manufactured and finally distributed.

The producer is not the wholesaler and the manufacturer even is not always the original producer. As an example, take tinned meat, the original producer of the beef is the farmer. The manufacturer of the corned beef or potted tongue may be and frequently is, both manufacturer and wholesaler. To a certain extent he is also a producer, for the article when it leaves his packing establishment differs from that which has left the farmer. The wholesaler, on the other hand, very rarely adds to or alters the product in which he deals. His function is to buy and store in large quantities and to provide the retailer from time to time as becomes necessary. The wholesaler is, in effect, the agent between the producer or manufacturer and the retailer. The retailer acts as a distributor to the consumer, unless his place is taken, in a rationing scheme by officials of the Government.

At just what stage in the productive process a government should step in with control is not always easy to determine. The policy adopted will depend in great measure upon the need for state interference, the ends to be sought by such interference and the attitude of the people. When there is urgent need for conserving foodstuffs, when the abuses of hoarding and profiteering become widespread and when public opinion demands a 
remedy a government will frame its control policy to meet the evils that cause most suffering and hardship. Rationing, which is always the last resort, may be applied only to manufacturers at first, and then to consumers. As the evils which government control are designed to correct are not confined to any particular stage of production or class, it seems to have greater possibilities of success when it is extended over the entire movement of a commodity and applied to all classes. To regulate the profits of one class, for example, while allowing other classes to reap what they can is an unfair discrimination, provided, of course, there exists no special reason for such discrimination. In not extending control from producer to consumer the beneficial effects at points regulated will be liable to be offset at points unregulated.

The policy of voluntary cooperation pursued by the Food Administration naturally tended to lesson restrictions. As maximum production was sought, there was a marked tendency to allow producers to go unregulated. It was thought that a strong patriotic appeal coupled with voluntary agreements would act as a restraint upon producers from taking excessive profits. The difficulty of determining excessive profits in the face of rising costs very often created the impression that these appeals were ineffective. Moreover, the fear that the government might at any time assume drastic control over a business impelled many to seek for an official definition of profits for individual businesses. The Food Administration likewise, realized the futility of attempting to enforce "reasonable profit regulations" without a specific determination of what these profits should be. Thus, by the very force of circumstances our policy of price control gradually shaped itself. Maximum margins were declared for manufacturers, wholesalers, and brokers. These maximum were agreed to by many producers, manufacturers, and wholesalers, and thus stamped our policy as one of indirect control, rather than one of direct price-fixing.

It will be understood from what has been said, that 
control, whether of articles or of price calls for some interference with the normal factors of production, distribution and consumption. Under the operation of the ordinary laws of economics, supply and demand are automatically regulated, with price as the magnet. If the supply falls off, while the demand remains stable or increases, there is immediately set up a current of attractive forces between price and supply, which ultimately tends to bring supply into harmony with demand. When the government interferes with either the supply or the price of a commodity, it is obvious, that the same laws operate but under changed conditions. Upon the adaptation of the government to these changed conditions depends in a large measure the success or failure of any system of control.

The problem of government control is essentially the same as that of monopoly control. In both cases a sufficient amount of the commodity must be controlled to exercise an influence upon price.

The so-called Law of Monopoly Price does not tell us what price will be fixed for an article; its statement is general and more negative than positive in meaning. Monopolists can not charge any price they wish, if they seek maximum profits. Granting a more or less complete control of a commodity, there is still the uncontrollable factor of demand with its fluctuations and possible substitutes to deal with. Uutil the monopolist can regulate demand with the same ease as he can regulate supply, his control over price will be far from being arbitrary. While the same in many respects, governmental control differs from monopolistic control in this: that it does not depend upon demand for its profits. The demands of the people in the sense of their power to purchase are not heard, and do not have to be considered as carefully by the Government as by a private monopoly. In view of this fact, the Government has more freedom in establishing a price; it may for the time being in order to conserve an insufficient supply set its price much higher than the average market price. 
But the complications of government control, are exceedingly great. Not one but many commodities must be controlled. The Monopolist works for his own interest; government officials have an odious task to perform which opposes individual interest in behalf of general welfare.

In studying different systems of price control, one becomes aware of a difference in the degree of control exercised. How far did the policy of state control extend? How drastic was the scheme of rationing and how directly did the Government fix prices? What punishments and penalties were laid down for infractions of the law? These and kindred questions naturally suggest themselves to the mind, and will be examined with reference to the Lever Food Control Act in the next chapter.

Price-fixing or Price control legislation may be (1) Direct, and (2) Indirect. Direct price-fixing comprises all those laws and regulations of the government which aim to set a specific price, whether maximum or minimum upon commodities. ${ }^{2}$ Indirect price-fixing includes all other regulatory measures which may or may not result in a fixed price. Control of profit margins is a typical example of the indirect method of fixing a price. The sugar refiner agrees that his margin of profit will not exceed $\$ 1.30$ per hundred pounds. Now if the government becomes a large enough purchaser of raw sugar, it can sell this to refiners at cost, to which is added the refiner's margin. If in addition, the jobber's margin for handling is determined, and added to the cost, the price of a pound of sugar to the consumer can be fixed with a fair degree of precision.

The causes which induce price-fixing are usually: (1) shortage in the supply of commodities; (2) profiteering and other practices which result in hardship and suffering to the consumer. It is especially during some abnormal time, such as during a war that these causes are

2 Cf. L. H. Haney, Price-Fixing in the United States during the War. I9r9, p. 3. 
operative in their worst forms. The instinct of self-preservation on the part of both consumer and dealer quickly manifests itself at the mere possibility of a shortage in foodstuffs. The consumer loses no opportunity to secure as large a store of supplies as he can, while the dealer anticipating higher profits as the supply diminishes holds back his goods. ${ }^{3}$ Thus in addition to the real shortage there is created an artificial shortage due to the actions of both consumers and dealers. It is impossible to estimate the superadded shortage which results from such hoarding. During the war, it is perhaps no exaggeration to say, that stock retarded amounted to almost one third of the entire supply. Flour, sugar, coal, and potatoes are usually the first commodities to feel the result of an increasing demand. Producers, wholesalers, and manufacturers, aggravate the situation by retarding the flow of goods in order to reap speculative prices, or as in the case of manufacturers by buying in larger quantities than usual in order to protect their business.

Overbuying on a rising market also induces Government control over prices. Once assured of positive shortage in a commodity with small possibility of increasing it, the producer and dealer know that prices may be determined by what the public will bear. In many cases secret agreements are made between dealers for the purpose of maintaining high prices.

That these two are the chief causes in provoking governmental control is the opinion of every group of legislators who have attempted to regulate prices. The Food Control Act, was the basis for the whole of war-time control of food and fuel in the United States. The act states its aim "to assure an adequate supply and equitable distribution, and to facilitate the movement, of foods, fuels, feeds, including fuel oils and natural gas, and fertilizer ingredients, tools, utensils, implements, machinery and equipment required for the actual production of

3 Cf. Food Production, Conservation and Distribution-Hear. ing before Committee on Agriculture, (House) May I, 1017, pp. 72-73. 
foods, feeds, and fuel, hereafter in this act called necessaries; to prevent, locally or 'generally, scarcity, monopolization, hoarding, injurious speculation, manipulations, and private controls affecting such supply, distribution, and movement; and to establish and maintain governmental control of such necessaries during the war"....

President Wilson stated the purpose of the Food Control Act on May 19, 1916 as follows: "The objects sought to be served by the legislation asked for are: Full inquiry into the existing available stocks of foodstuffs and into the costs and practices of various food producing and distributing trades; the prevention of all unwarranted hoarding of every kind and of the control of foodstufis by persons who are not in any legitimate sense producers, dealers, or traders; the requisitioning, when necessary for the public use, of food supplies and of the equipment necessary for handling them properly....".

Lord Rhondda, food controller of Great Britain showed the purposes of food control in that country in his statement to the public: "My aim is to safeguard the interests of the consumer, and to do away with profiteering altogether, and to prevent excessive profits of any kind-the policy is to limit profits at every step from the producer to the consumer, and at the same time to regulate supply."

A distinction is sometimes made between maximum and minimum fixed prices. The maximum fixed price states the upper limit of charge for a commodity. To demand a higher price than the legal maximum would render the seller liable to prosecution. The maximum price is designed primarily to protect consumers from excessive charges. Its purpose is to limit profits, but not to such an extent that production will be curtailed. The greater the need for increased production, the higher the maximum should be fixed. In times of great shortage marginal or higher cost producers must be attracted by the promise of profits, which in normal times, they would 
have small possibility of getting. But to fix the maximum price so as to include high cost producers increases the differential between these producers and low cost producers. By way of lessening these extra profits to the latter, a government may fix two prices-a minimum for low cost producers and a maximum for high cost producers. This, however, is only an apparent solution of the difficulty. For, unless either one of these prices is specifically applied to individual producers or manufacturers, the maximum price is taken by all. As costs vary greatly in the same line of business, fluctuate often, and are easily concealed, the difficulty of classifying producers on a cost basis is almost insuperable. The drive for further production may become so urgent, that the curbing of profits is kept in the background.

A minimum price in a somewhat different sense is sometimes fixed without reference to a maximum price. In such cases it has the character of an agreement or promise on the part of the government to maintain a stated price for a commodity, even though market conditions might call for a lower price. On the other hand, the market price may go above the minimum price. Farmers, who are obliged to wait several months between the sowing and selling of their crops. consider a fair minimum price, a protection against possible decreases in market prices. The conspicuous instance of a minimum fixed price in this sense was that of wheat for which two dollars a bushel was guaranteed by the government of the United States. 


\section{CHAPTER II.}

\section{BEGINNINGS OF GOVERNMENT CONTROL.}

No elaborate array of statistical data is needed to discover the trend of prices from the declaration of the European war in 1914 to our own entrance into the conflict in 1917. The trend was unmistakably upward for practically every commodity. To understand the real significance of this movement, and to measure it more carefully, will, however conduce to a better appreciation of one of the chief factors that influenced government control of food products.

Price fluctuations in the United States during the quarter century preceding the outbreak of the war in Europe on July 28, 1914, were slight when compared to the sudden rises in the latter part of 1916, and the first half of 1917. A glance at the index number for "all commodities" from the year 1890 to 1914 shows the greatest variations to be a drop of 10 per cent in 1894 , and a rise of 8 per cent during 1900 and again in 1902.4

Indeed, from 1898 to 1913 , there has been a steady upward tendency for prices, the culumative effect of which was large. The index number for "all commodities" advanced from 69 in 1898 to 100 in $1913^{5}$ But these rises were eclipsed both in magnitude and suddeness by those in the latter part of 1916, and in the first half of 1917.

As will be seen from Table I, wholesale prices in the United States remained comparatively stable during the first year and a half of the European war. ${ }^{6}$ Between 1915 and 1916, the increase in "building materials" was but 7 per cent, the increase in "house furnishings" 11 per cent. The greatest advances took place in food which rose 2 per cent, cloths and clothing which rose 27 per cent,

4 A comparison of Prices during the Civil War and the Present War, Mimeograph copy. War Industries Board. I9I9.

5 Bureau of Labor Statistics. Bulletin, No. 149.

6 International Price Comparisons, Dept. of Commerce, p. II. 
and metals and metal products which rose 51 per cent. The war had raged in Europe for nearly two years. yet the rise in "all commodities" in this country was but 23 per cent during that period. But because this general advance was unequally distributed among commodities it would most naturally be measured by the average mind by its maximum and not its minimum swing in particular commodities.

\section{TABLE I.}

Index numbers of Wholesale Prices, by groups of commodities and by years, 1913 to 1917, and by years and months, 1917 and 1918. (1913-100) ${ }^{7}$

Year and Month

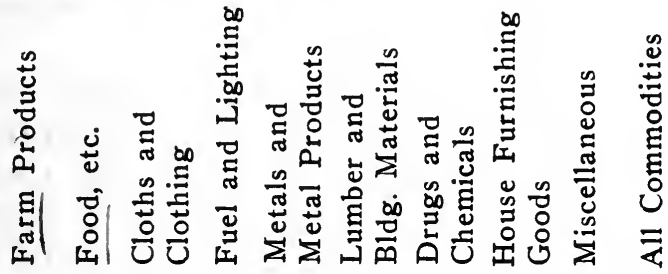

\begin{tabular}{|c|c|c|c|c|c|c|c|c|c|}
\hline Average for $1913 \ldots 100$ & 100 & 100 & 100 & 100 & 100 & 100 & 100 & 100 & \\
\hline Average for $1914 \ldots 103$ & 103 & 98 & 92 & 87 & 97 & I03 & 103 & 97 & \\
\hline Average for $1915 \ldots 105$ & 104 & 100 & 87 & 97 & 94 & II3 & IOI & 98 & \\
\hline Average for $1916 \ldots 122$ & 126 & 127 & II5 & 148 & IOI & 143 & 110 & 120 & \\
\hline $\begin{array}{l}\text { verage for } 1917 \ldots . .188 \\
\text { 1917 } 1918 \text { 248 }\end{array}$ & ing & 181 & 169 & 208 & 124 & I85 & 155 & 153 & \\
\hline .....147 & $150^{\circ}$ & I6I & 170 & 183 & 106 & 144 & 128 & 137 & \\
\hline February & 160 & 162 & 178 & 190 & 108 & 146 & 129 & 138 & \\
\hline$\ldots \ldots \ldots 162$ & I6I & 163 & 181 & 199 & III & I5I & 129 & 140 & \\
\hline ........ 180 & 182 & 169 & 178 & 208 & 114 & I55 & 151 & 144 & \\
\hline ........196 & I9I & 173 & 187 & 217 & 117 & 164 & 151 & 148 & \\
\hline ........196 & 187 & 179 & 193 & 239 & 127 & 165 & 162 & 153 & \\
\hline ....... Ig8 & 180 & i87 & 183 & 257 & I 32 & 185 & 165 & I5I & \\
\hline ......204 & I80 & 193 & 159 & 249 & 133 & 198 & 165 & 156 & \\
\hline ......203 & I78 & 193 & I 55 & 228 & 134 & 203 & 165 & 155 & \\
\hline ......207 & 183 & 194 & 142 & 182 & 134 & 242 & 165 & 164 & \\
\hline Tovember $\quad . . \ldots \ldots 2$ II & I84 & 202 & I5I & 173 & I35 & 232 & I75 & 165 & \\
\hline${ }_{1918}$ December $\ldots \ldots 204$ & 185 & 206 & 153 & 173 & I35 & 230 & 175 & 166 & \\
\hline ..205 & 188 & 209 & 169 & I73 & 136 & 216 & 188 & 178 & \\
\hline .....207 & 186 & 213 & 171 & 175 & 137 & 217 & 188 & 181 & \\
\hline .......2II & I78 & 220 & 171 & 175 & 142 & 217 & 188 & 184 & \\
\hline$\ldots \ldots \ldots 217$ & 179 & 230 & 170 & 176 & 145 & 214 & 188 & 193 & \\
\hline
\end{tabular}

7 Monthly Review of the Bureau of Labor Statistics, Feb. I918, p. 16; 1919, p. 115 . 


$\begin{array}{llccccccccc}\text { May } \ldots \ldots \ldots \ldots \ldots \ldots 212 & 178 & 234 & 172 & 177 & 147 & 209 & 188 & 197 & 191 \\ \text { June } \ldots \ldots \ldots \ldots \ldots \ldots 214 & 179 & 243 & 171 & 177 & 148 & 205 & 192 & 199 & 193 \\ \text { July } \ldots \ldots \ldots \ldots \ldots \ldots 22 & 185 & 249 & 178 & 183 & 153 & 202 & 192 & 192 & 198 \\ \text { August } \ldots \ldots \ldots \ldots \ldots & \ldots 229 & 191 & 251 & 178 & 183 & 156 & 207 & 227 & 191 & 202 \\ \text { September } \ldots \ldots \ldots \ldots 236 & 199 & 251 & 179 & 183 & 158 & 206 & 233 & 195 & 207 \\ \text { October } \ldots \ldots \ldots \ldots \ldots 223 & 199 & 253 & 179 & 186 & 157 & 204 & 233 & 197 & 204 \\ \text { November } \ldots \ldots \ldots \ldots 219 & 203 & 253 & 182 & 186 & 163 & 201 & 233 & 207 & 206 \\ \text { December } \ldots \ldots \ldots \ldots 221 & 207 & 246 & 183 & 183 & 163 & 182 & 233 & 204 & 206\end{array}$

The effect of the war upon American prices can best be noted, however, over a longer period. Using the grouping of the Bureau of Labor Statistics one finds that the average index number increased from 1913 to November 1918, in the case of farm products 119 per cent; food, 103 per cent. cloths and clothing 153 per cent, metals and metal products 86 per cent, lumber and building materials 63 per cent, house furnishings 133 per cent; miscellaneous articles 107 per cent.

After war had been declared the rise in price levels was much more pronounced in European Countries than in the United States. In England, for example, the index number rose from 102 in 1913 to 123 in 1915, while in the United States, for the same period, the rise was but 1 per cent. In 1916 and in the early part of 19117, this margin between the index numbers of the two countries increased. Then prices in the United States took a sudden upward swing.

Once started, the rise in prices in this country was extraordinarily rapid. "By August, 1916, prices stood 25 per cent above the prewar level; by February, 1917, 50 per cent, by May 1917, 75 per cent, and by September 1918, 100 per cent above it.""

The grand march of prices did not begin in this country until we had declared war. In April. 1917 the "all commodities" index number rose from 156 to $170 .{ }^{9}$ The prices of metal rose to unprecedented heights. The weighted index number for the whole metals group made by the War Board Price Section. rose from 247 in March the month before war was declared by the United States, to 333 by July following. Basic pig iron, f. o. b. at Pittsburgh rose from $\$ 32.25$ to $\$ 52.50$ in the same period; steel plates at Pittsburgh rose from $\$ 4.23$ to $\$ 9$ nearly 
800 per cent above their prewar quotation. ${ }^{10}$ The index for the food group advanced from 142 in March 1917 to 157 in April and to 167 in July of the same year. The clothing group rose from 157 in March to 187 in July. The clothing group rose from 159 in March to 187 in July.

The above figures taken from the Price Section of the War Industries Board,* show slight differences when compared with similiar index number compiled by the Bureau of Labor Statistics as shown on pages 17 and 18 . The tables compiled by the War Industries Board show that farm products increased 36 points from March 1917 to July of the same year; food rose 19 points, cloths and clothing 18 points, metals 58 points and all commodities 25 points during these five months.

Retail prices, on the other hand, are a much better index of the cost of living than wholesale prices. For between the wholesaler and the retailer there are many items of cost which enter in the final price of the article. Retail prices over short periods of time do not fluctuate as often as wholesale prices. It can easily happen, therefore, that reductions in wholesale prices are made several days and sometimes several weeks before retailers adjust their prices. Over long periods of time, however. retail prices tend to change in the same proportion as wholesale prices. Thus it will be seen from the following table that retail prices followed the same trend during the war as wholesale prices, with few exceptions. The data here given was collected by the Bureau of Labor Statistics, and indicates that the retail price of food on the whole in January, 1914, was five per cent higher than in January, 1913. In January, 1917, the rise over January, 1915, amounted to 30 per cent. Between January, 1917 , and January, 1918, the rise was 33 per cent. The peak was reached in 1920 ; in January of that year prices rose 65 per cent over those of 1917 and 105 per cent over those of 1913.

Io Ibid, p. 29

* The price Section of the War Industries Board under the direction of Wesley $C$. Mitchell, included over I,37 I Commodities it. its price index. 
Beginnings of Government Control.

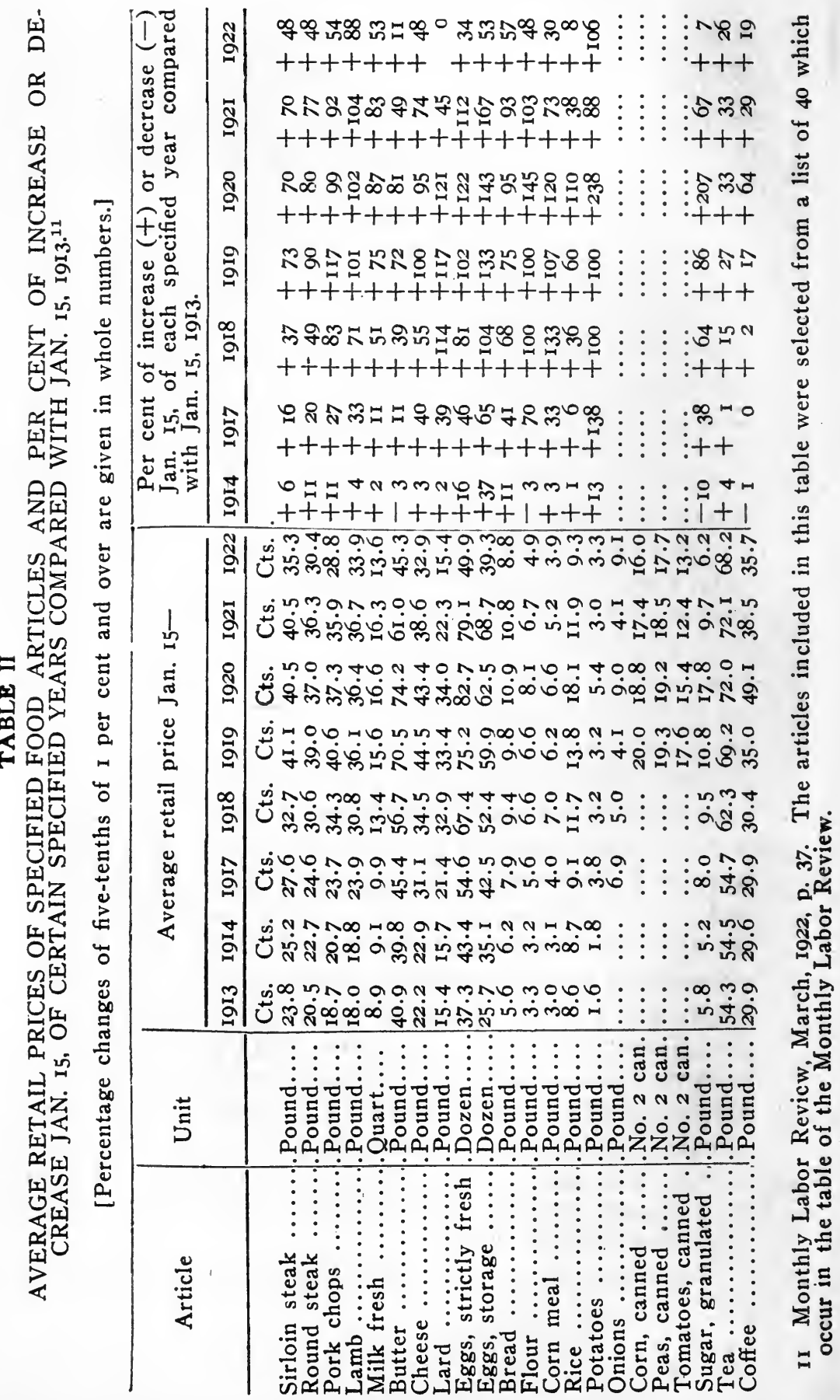


The following 22 articles, weighted according to the consumption of the average family, have been used in estimating the percentage of increase or decrease in prices; sirloin steak, round steak, rib roast, chuck roast, plate beef, pork chops, bacon, ham, lard, hens, flour, corn meal, eggs, butter, milk, bread, potatoes, sugar, cheese, rice, coffee, tea.

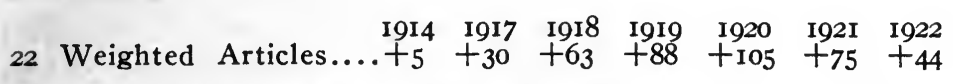

These extraordinary rises in prices in the United States during the latter months of 1916 and the early part of 1917 were intensified by our entrance into the conflict. The growing shortage of food supplies, the cries of profiteering, the demand on the part of the people "that something be done" were strong enough motives to urge the Government to decide upon some kind of regulation.

The United States had been since the beginning of the war, the food source for the Allies. As the war continued and the devastation of Europe increased, the demands on American markets grew with alarming magnitude. From Table No. I it was shown that prices on the whole in the United States were comparatively stable till the latter part of 1916. That the growing demands of Europe upon our supplies was responsible in a great measure for the upward pressure on prices may be readily seen by noting the increase that year in exports, the greater part of which took place in the later months of the year. During the year ending with June 1914, Europe had drawn upon American markets for products, amounting to $\$ 1,471,266,488$, which exceeded the export figure for 1913 by $\$ 96,738,732$. During the year 1917 , the Allies took from our shores $\$ 4.307,310,138$ in raw materials, manufactures and foods, or almost four times the amount by value exported in 1913. That prices should rise under such sudden and enormous demand was to be expected. The increase of exports in 1915 was 33 per cent over the figure of 1913, while the increase in 1916 was 103 per cent.

The wheat shortage in itself was a problem that might 
have called forth some form of government control. The annual wheat consumption of Great Britain, France and Italy is over $900,000,000$ bushels, of which $100,000,000$ bushels is ordinarily imported from the United States. Of the annual $\mathbf{7 6 0 , 0 0 0 , 0 0 0}$ bushels produced in this country the domestic consumption is about $646,000,000$ bushels. European production of wheat became less and less as more men were withdrawn from agriculture. The British carrying vessels were being constantly reduced in number by submarine warfare and the number that remained could not be spared for the long haul to Australia for wheat. Siberian wheat was cut off by the closing of the Dardanelles. The spring of 1917 brought enormous orders from Europe for American wheat. The wheat crop of 1917 in this country was the smallest since 1911, and almost $400,000,000$ bushels below that of 1916 . The wheat market beeame the school for speculative buying which further added to the increase of prices.

Before the war Great Britain imported annually about $2,060,000$ short tons of sugar of which about 70 per cent was imported from Germany and Austria. During the war she found it necessary to turn to the United States and Cuba for supplies of sugar. The sugar exports from this country jumped from 96,862,462 pounds in 1913 to $1,685,195,537$ pounds in 1916 . This demand for sugar was bound to cause higher prices.

Another factor which exercised no little influence in raising prices all over the world was the almost daily loss of tonnage. Though our own losses were compensated for by interned vessels, the losses of the Allies became so great as to almost threaten defeat. Commerce, so seriously handicapped, threw a still greater strain upon American agriculture and industries.

Perhaps, the strongest reason for setting up the machinery for Federal control over the prices of foodstuffs may be found in the great saving it would effect in the purchase of Government supplies for the Army and Navy. To have allowed each department of the Army and Navy to purchase its own supplies from whatever 
source it could, would have resulted in dangerous delays. unfilled orders and exorbitant prices. Moreover, each department would require a special board of experts to determine whether prices were reasonable, and to make allotments of the various contracts. The necessity of some central board, whose business it was to provide for all those contracts at prices which bore some relation to the cost of production plus a reasonable profit was indeed, apparent. Furthermore, the question of priorities in times of such urgent need was vital. It would have been a mistaken policy, or rather the breakdown of efficiency, for example, to allow street cars, to have the first option upon steel, wood and furnishings, while battleships, submarines, and other war apparatus were without materials for their manufacture. As Secretary Lane said "The government must have a board that will say who comes first and what comes first; otherwise all will be confusion, and the law of competition, instead of working to lower levels will work to raise them; for instead of industries competing against each other for orders, the purchasers will be bidding against each other, as at an auction sale, as they are doing to-day." Such a board with powers of licensing purchases, might regulate and steady, or even eliminate much of the demand and thus influence prices.

These requirements could have been obtained no doubt, without resorting to any policy of fixing limits on prices. The Government might have determined the price it would pay for its purchases, and allow general trade to go unregulated. The result of such a policy, however, would be, either the probability of not having Government orders filled entirely, or, on the other hand, a disregard of the necessities of consumers, which, if applied to foodstuffs, would entail serious consequences. If the price for government purchases was above that paid, or able to be paid by consumers, its orders would be filled to the neglect of the latter. But if the Government's price was considerably lower than the market price, producers would be in no hurry to make contracts for Gov- 
ernment purchases. The purchases of the Allied Governments were also an influencing factor. As their necessities were more urgent than ours, their prices would be higher.

There is fairly good evidence that greater prosperity was enjoyed by many people of the United States during the war than either before or after it. Labor, skilled and unskilled was in such a demand that workers were safe in voicing their demands for increases. There were plenty of jobs for all; even boys and girls could earn a fairly good pay. These high wages were the means of bringing to industry many 'marginal' workers, whose incomes considerably increased the family prosperity. In most cases too, these surplus earnings went towards higher standards of living and indulgence in luxuries. It is true that for some, the cost of living advanced more rapidly than the rate in wages. But business men, manufacturers and other producers, who make up a considerable portion of the population, reaped higher profits than ever before and these as consumers probably did a great deal to diffuse their lucrative gains.

The increased consumption of foodstuffs, shoes and clothing due to military life, also had an effect upon prices. The healthy appetites of those who spend most of their time in working or exercising in the open air leaves no doubt as to the increased consumption of foodstuffs by a large army and navy. "A soldier whether at the front or not eats about half as much again as in private life. ${ }^{12}$ The shoes and clothing of a soldier are consumed more quickly than the same articles of a civilian. Though durable they are exposed to a great amount of wear and tear. Certainly as a factor in increasing prices, the additional consumption due to a large army and navy can not be overlooked.

The most popular explanation of high prices during the war was contained in the one word "profiteering." Editors and declaimers did much to arouse the public against this exaggerated abuse, for the blame for high 
prices must be placed upon some one, and it was easiest to shoulder it upon 'middlemen', 'food gamblers'. 'speculators' etc. Doubtless some increase in prices was due to the wider margins of profits taken all along the line from producer to consumer. This is, in fact, what we should have to expect. All classes received greater compensation for services during this period of inflation, and higher profits were nothing but higher wages for the business man and producer. On July 11, 1917 President Wilson issued his address on profiteering to the mine owners and manufacturers of the country. In his pronouncement the President did not touch on details nor commit himself to any particular method of control, but merely wished to direct the attention of the country to a condition that called for legislative action.

The indictment of "profiteering" did not apply to all. Thousands of men were imbued with the proper spirit and sacrificed gains they could have taken with impunity. Honest dealers welcomed any Federal control which would enable them to conduct their businesses without the serious handicap which they must experience when pitted against market manupulators, food gamblers, and hoarders. ${ }^{13}$ The fact is that profits are so uncertain and fluctuating and are influenced by so many factors which change entirely the aspect of justice in taking them, that a precise definition of profiteering is practically impossible.

"There has been one Bureau of Washington whose aggregate expenses now run beyond a million dollars. that has seemed to make its especial business distilling into the public mind every kind of vicious idea about business.. It has sent out report after report showing the enormous profits of this or that company or trade. But what kind of profit? always the profits on the invested capital! Rarely, if ever have these profits been figured on gross sales. Why? Because, however large the profits cited have been on invested capital, the average profits on sales have been usually less than five or six

13 Congressional Record (House), June 18, 1917, Vol. 55, p. 3794. 
per cent, often half this, and in the case of the criminal meat packers, they have often been below two per cent. And this brings us to the very heart of profiteering. (I make bold to say that the public has relatively little interest in the earnings upon capital. in any event). It will often happen that one dealer will make two or three times as much on his invested capital as his neighbors and competitors, and yet sell his goods to the public at a lower price, or what is the same thing, sell better goods for the same money. He will do this because he undersells his competitors. The matter is simply this: Some merchants will turn their capital over, ten, twenty, and even twenty-five times a year (in the case of some retail grocers). Others only four or five times a year. That is their year's sales will total five, ten or more times the sum they have invested. And in general. the higher the turnover, the lower the days expenses, and therefore lower prices to the public !14

"It will do no good, of course, to rail at lucky winners in the lottery. The public was greatly mistaken in attributing low prices to the "stranglehold" of wicked bondholders, and is equally mistaken to-day in attributing high prices to the personal turpitude of profiteers. How can we blame a business man (especially one who as an officer of a corporation, acts in the interests of others whose capital he is managing) for getting the best prices he can? We can not expect him to sell below the market. In fact, if market conditions cause profits to fall into his lap, he would be recreant in duty to throw them away." 15

Professor Fisher might have added to this statement an explanation of the illusory nature of profits for a going concern, and show how the large profits of one period are absolutely necessary to retrieve the losses of another period.

Abnormal rises in prices always create suspicion in the

I4 Carl, Snyder, "Who is Profiteering?" McClure's Magazine, March, 1920, p. 23.

I5 Irving Fisher, "Stabilising the Dollar," p. 59. 
minds of many of abnormal profits. A more rational explanation of high prices and one that eliminates much of the suspicion harbored about profiteering is that which looks to the amount of money in circulation in a country. Values are measured by prices and prices are expressed in terms of money. The value of commodities decrease when money becomes plentiful and hence prices rise. When a government issues an over supply of currency, as happens frequently in times of war, prices invariably rise. The fallacy of overlooking the expansion of money in a country and of making profiteering the cause of high prices is explained by Professor Hollander as follows:

Profiteering "is a symptom of the disease, not the disease itself. Profiteering is the effect, not the cause of the high cost of living. Those who have been trying to make the American people believe that profiteering causes high prices are in a class with the quacks who will tell $a_{1}$ consumptive that his loss of weight is due to his high color, instead of saying that both are the symptoms of a tissue-destroying bacillus. The answer is that inflation is due to financial mistakes of the Administration at Washington, (1) while we were getting ready for war, (2) while we were at war, and (3) after the war was over. During each of these periods, the Treasury permitted. and indeed, encouraged an increase in the country's money supply. and the certain prospect of rising prices." 16

Turning our attention from the causes of governmental control over prices, we shall now consider the legislative act from which the Food Administration took its rise. The Lever Food Control Bill (H. R. 4961) passed the senate after much opposition and debate on August 10, 1917. The Lever Bill was designed to prevent abnormal rises in prices of foodstuffs and fuel to the consumer, to provide a plan for Army and Navy necessi-

I6 Jacob H. Hollander, New York Sunday Times, May 2, I920, "How inflation touches every man's pocket-book." 
ties and to increase our exports of food to the Allied Nations..$^{17}$

As originally constructed the bill contained provision for the fixing of both maximum and minimum prices. The Committee, however, influenced by the unsuccessful attempts of European countries with the 'minimum' struck out this feature of the plan from the Bill. ${ }^{18}$

This Bill was under long and vexatious consideration not only in Congress but wherever its effects would be felt. Its opponents declared that it was an autocratic imposition on the American public. "It is class legislation pure and simple. You hold up the farmer as a class" (Congressman Young). ${ }^{19}$

Senator Gore denounced it as the "sweepings" of all British and Canadian Food Acts, and predicted that if passed "it would cause losses to producers (in 1917) of $\$ 250,000,000$ in wheat and $\$ 500,000,000$ in corn and result in famine next year through reduced production." Senator Lodge said that price fixing was as old as organized society itself, but in almost every case it was a dismal failure.

The Press leveled its guns at the measure also; the New York Evening Sun pointed out the disasters that would result from its passage namely: "reduced production, chaos in marketing. the withdrawal of capital and expert skill from the food trades, panicky buying, high prices and grievous shortage at the points of consumption."

The Lever Bill so bombarded, was finally passed on August 10th, 1917. Pending its passage, however, President Wilson had appointed Mr. Hoover as Food Administrator on May 19, 1917. ${ }^{20}$ As this bill is the basis for the whole of war-time control of both food and fuel, it will be of value to analyse it more fully.

The sweeping control which this statute provides for

I7 Congressional Record (House), June I8, I917, Vol. 55, p. 3799

I8 F. O'Hara, Catholic World, July 1917, p. 524.

I9 Congressional Record (House), June 18, 1917, Vol. 55, p. 3799

20 "Food Administration," I917, p. 6. 
can be clearly seen from its terminology. The purposes of the act are:

"To assure an adequate supply and equitable distribution, and to facilitate the movement, of foods, feeds, fuel, including fuel oil and natural gas, and fertilizer and fertilizer ingredients, tools, utensils, implements, machinery, and equipment required for the actual production of foods, feeds, and fuel, hereafter in this act called necessaries; to prevent locally or generally scarcity, monopolization, hoarding, injurious speculation, manipulation and private controls affecting such supply, distributions, and movement; and to establish and maintain government control of such necessities during the war....."

It furthermore makes it unlawful for any person willfully to destroy any necessaries for the purpose of enhancing the price or restricting the supply thereof: and prohibits any arrangement or practice of limiting facilities for transportation, production, harvesting manufacturing or storing.

Section 5 sets forth the means to be used to prevent such evil practices. By force of this Section the President is given authority to license the importation, manufacture, storage, mining or distribution of any necessities. In this section is contained the chief feature of the United States price control policy, and that which most distinguishes it from the policies of other European countries.

"The backbone of the administration of war-time control over foods lay in the license system." ${ }^{21}$ As contained in Section 5. it gave the President authority to bring under license control any dealer in necessaries except those exempt in the law. By virtue of this section the President is empowered to control by license all businesses engaged in the manufacture, importation, storage, mining or distribution of any necessaries. After a date fixed by the President, no dealer engaged in any of the above named occupations could pursue the same without 
a license, exception having been made for those engaged in farming, cooperative associations of farmers, common carriers and retailers whose gross sales did not exceed $\$ 100,000$ per annum.

Section 6 defines necessaries and provides that any person who willingly hoards any necessaries shall upon conviction be subject to a fine not exceeding $\$ 5,000$ or be imprisoned for not more than two years.

Section 10, authorized the President to requisition foods. feeds, fuels, and other supplies necessary to the support of the Army or maintenance of the Navy; when such actions take place he shall ascertain and pay a just compensation therefor.

Section 14 provides that whenever the President should find that the production of wheat required stimulation he could determine and fix a reasonable price for wheat. A guaranteed price of not less than $\$ 2$ per bushel was fixed for No. 1 Northern Spring wheat, binding till May 1, 1919.

Section 18 makes the appropriation of $\$ 2,500,000$ from the Treasury of the United States for the administration of the act.

Section 24 determines that the Act should cease to be in effect when the existing state of war between the United States and Germany shall have terminated.

The license system, as has been said, was the soul of Price Control. The system required that all dealers, producers and handlers of foodstuffs, with some exceptions must be registered by the Food Administration and that each licensee should not receive more than a "reasonable margin of profit" on the "cost basis" of production. This meant that the price should be determined from the elements in the entrepreneur's cost of producing the commodity. Since these costs differ widely not only for different articles but for the same article, the rule was difficult of application. Yet if the plan could carry any suggestions of fairness these difficulties had to be met and overcome. To meet these different variations of the cost method of price fixing was therefore em- 
ployed. ${ }^{22}$. In some cases, prices were fixed after the production had been completed; in other cases. prices were fixed before the production was undertaken. Ante-production prices were fixed upon what the average costs to the producer should be, thus setting a standard of pricecosts. The difficulties to be met by the price-fixing agencies were two-fold; first, the price must be high enough to insure necessary production. Secondly, the price must be low enough to prevent excessive profits.

The cry of the country during the years 1917 and 1918 was for greater production to meet the demands of our own and the Allied Forces and also that of consumers. To stimulate production theoretically the cost price of the lowest and least efficient producer should be taken as a standard. Practically, however, it was found that some of the very high cost producers were so inefficient that their costs had to be disregarded. The cost chosen was often called the "bulk-line cost"- that is, the cost that covered the bulk of the production. ${ }^{23}$ This cost was usually found at the point which included from 80 per cent to 90 per cent of the production. ${ }^{24}$ Thus the "bulkline cost" was not necessarily the highest cost.

The "cost basis" having been accepted as the rule in determining prices, it became necessary to work out a reasonable margin of profit. At first only the general principle was formulated that no dealer was entitled to a greater per cent of profit than he made in pre-war times. Mr. Hoover in a speech before the Pittsburgh Press Club in April 18, 1918 said in part: "I do not believe that any person in the United States has a right to make one cent more profit out of any employment than he could have made under pre-war conditions."

The average percentage of profit was figured on the basis of the three immediate pre-war years. It soon be-

22 Simpson, K., Price-Fixing and the Theory of Profit, Quar.terly Journal of Econ., Nov., I9I9, p. I4I.

23 Simpson, K., Quarterly Journal of Economics, Nov. 19r9, p. 147.

24 Taussig, F., Price-Fixing as seen by a Price-Fixer, Quarterly Journal of Econ., Feb. I919, p. 219. 
came evident, however, both to the Food Administration and to dealers that a more definite rule of profits was needed. The effectiveness of the regulation depended to a large extent upon the rigor with which it was enforced. Moreover, its lack of precision furnished opportunities for unscrupulous dealers to pad costs and thereby take large profits.

With these shortcomings in mind, the Food Administration on April 6, 1918, announced a series of definite maximum margins of profit for wholesalers and retailers on the more important commodities. The plan adopted was to fix two margins; the higher margin was to be made applicable to the dealers with high costs, and the lower margin to those of lower costs. There was no thought of making these margins absolute and final. Possible exceptions might be allowed, but the burden of proof rested upon the dealer who violated them.

These margins were released by the Food Administration from time to time over the period from April 6, 1918 to the signing of the armistice. They covered the most important foodstuffs such as sugar, wheat, flour, bread, lard, lard substitutes, hams, bacon, condensed and evaporated milk, rice, hominy grits, oatmeal, rolled oats, beans, corn, syrup, canned goods, etc.

With the system of maximum margins in operation, the Food Administration dispensed with the regular monthly reports from licenses.

Efforts to reach retailers before November 7, 1918 were largely left to the associated Food Administrators in each state, and to the publicity campaigns of the numerous "Fair Price Committees" through the country. No severer sanction than public stigma could be held over the heads of recalcitrant retailers, until the Food Administration issued on November 7, 1918 a series of retail maximums to which from time to time were added special regulations pertaining to single commodities.

The special licensee regulations were issued with such rapidity and promulgated in so many different manners-by press, by pamphlets, by notification of State 
Food Administrators, by typewritten sheet-that a chronological study of these would be confusing and difficult. It is much more satisfactory to arrange them arcording to distinct Food groups.

We have seen thus far the distinction between price control, price-fixing and rationing. The Food Control Act has been outlined and special features have been noted. The following chapters will be devoted to a more detailed study of the most important food problems faced by the Food Administration during the war. It is not easy to arrange these problems with fine regard to their importance, nor is it perhaps of any advantage to do so. Chapter III will consider the control of wheat, flour and bread; Chapter IV, the control of sugar; Chapter V, the control of meat and dairy products; and Chapter VI, the control of Canned goods. 


\section{CHAPTER III.}

\section{CONTROL OF WHEAT, FLOUR AND BREAD.}

There arose in 1917 a world-wide shortage of wheat which turned the attention of warring Europe more keenly than before to food supplies, and at the same time made the Allies greatly dependent upon American wheat production. In that year the total amount harvested in the United States was but $650,828,000$ bushels, with a carry over from the preceding year of $51,078,000$ bushels. The demands of the Allies for wheat were constantly increasing in proportion as their own production was diminishing. This will be clearly seen from the following table, which shows our wheat exports to France and England in 1913, 1914 and 1915.

Wheat Exports from United States. ${ }^{25}$

$\begin{array}{lccc}\text { Country } & \mathbf{1 9 1 3} & 1914 & \mathbf{1 9 1 5} \\ \text { France } & 4,931,708 & 5,536,731 & 49,878,655 \text { bu. } \\ \text { England } & 27,963,980 & 23,414,555 & \mathbf{5 5 , 4 5 9 , 3 2 8} \text { bu. }\end{array}$

Similarly, our wheat exports to other countries increased. The table following shows the tremendous increase of wheat exports in 1915.

Wheat Exports from United States to Europe. ${ }^{26}$
1913
1914
1915

$83,132,758$ bu.

$82,552,520 \mathrm{bu}$.

$231,859,859 \mathrm{bu}$.

European demand for our wheat in 1915, enormous as it was, could be satisfied because of the large yield in the United States in that year, which reached 1,025,801,000 bushels. The increase in production in 1915 over the figure for 1914 was $134,784,000$ bushels. The high level reached in 1915 dropped to $639,886,000$ bushels in 1916 , with a carry-over of $178,203,000$ bushels. This amount

25 Foreign Commerce \& Navigation of U. S., I9I7, p. 374.

26 Foreign Commerce \& Navigation of U. S., I917, p. 375. 
enabled us, however, to export to Europe $160,880,000$ bushels. ${ }^{27}$

Although in the fall of the latter year, a large area of winter wheat was sown, about one third of this failed to mature because of heavy frosts. The production, thus lessened, amounted in 1917 to $650,828,000$ bushels with a carry-over from the preceding year of 51,078,000 bushels. Such a decrease of wheat-stuffs was keenly felt in Europe.

The wheat situation, just outlined, confronted our legislators upon our own entrance into the war, and its difficulty and urgency, doubtless, made it the central problem in the organization of Government control of food-stuffs. It accounts also for the desire of President Wilson to insure greater production by providing farmers with a legally guaranteed price per bushel. The importance of this measure soon became evident, for Mr. Hoover in a report to the Food Committee estimated that the amount of wheat needed by the Allies in 1918 would reach 500 million bushels. ${ }^{28}$ Of this amount, he hoped that the United States would be able to supply a large part.

Now, the potential supply of wheat to meet this need was estimated as follows : ${ }^{29}$

Australia ...... 10 million bushels.

\begin{tabular}{|c|c|c|c|}
\hline Argentine & 40 & $"$ & $"$ \\
\hline Canada .. & .100 & $"$ & \\
\hline United States & .200 & $"$ & $"$ \\
\hline & 350 & $"$ & $"$ \\
\hline
\end{tabular}

The last figures show that, in addition to what was needed for home consumption, the United States could probably furnish the Allies with 200 million bushels. This amount, however (assuming that Australia, Argentine and Canada could not increase their supplies), still left a shortage for the Allies of 150 million bushels.

27 Foreign Commerce \& Navigation of U. S., 1917, p. 375.

28 Minutes of the Price-Fixing Committee, Appendix No. 40. The figure cited above included flour, bran and middlings.

29 U. S. Food Administration, Policies \& Plan of Operation (Wheat, Flour, Bread), p. 7. 
Could the United States so increase her production of wheat as to supply this desideratum?

It was, furthermore, problematical whether Australia and Argentine could ship their quotas to the Allies, for German submarine warfare had already made serious ravages in shipping, and had reduced British tonnage to such an extent that vessels for long hauls were out of the question. The fact is that neither Australia nor Argentine exported much wheat to the Allies during 1917, 1918 and 1919. By the defect of the other potential sources of supply, the United States and Canada thus became the wheat markets for the Allies during those years.

Such a demand upon our wheat fields brought with it higher prices for wheat. American and European buyers competed with each other in our markets, and prices rose rapidly. From March to May, 1917, the price increased $\$ 1$ a bushel for No. 2 red winter wheat at Chicago, reaching an average for May of $\$ 2.97$. No. 1 Northern spring wheat averaged $\$ 2.98$ at Minneapolis for the month of May. On May 11, the price at the Chicago Board of Trade was $\$ 3.15$ a bushel, at which point the Board was compelled to prohibit the trading in wheat futures and ordered a settlement of all outstanding contracts. ${ }^{30}$ This was the highest price in the history of the United States, being 50 per cent beyond the maximum during the Civil War.

It might seem that these prices would have been suffcient to stimulate the farmer to increase his acreage of wheat. Few farmers, however, had received anything like the above-named prices. The 1916 crop had long been disposed of for about $\$ 1.50$ per bushel ;1 the 1917 crop would not begin to move to the market till September. Between May and September the price might drop, and the farmer would naturally feel that speculators were reaping the fruits of his toil. With this idea in mind, then, Congress must evolve some plan to make

30 The Farmer and His Wheat, Collier's, Aug. II, 1917.

3I U. S. Food Administration, Minutes of Price-Fixing Committee, Appendix, No. 13. 
wheat culture attractive so as to insure the largest possible crop for 1918.

The food control act (Lever Act) was approved by the President on August 10, 1917. Congress, it is to be noted did not name a price for any other commodity but wheat for which a minimum of $\$ 2$ per bushel was fixed for the 1918 wheat harvest. This price did not apply to the 1917 crop; provision had been made by Congress, however, whereby the President was authorized, should he deem it necessary, to determine a reasonable guaranteed price for the crop that was now moving to the market.

The $\$ 2$ guaranteed price was 26 cents per bushel lower than the market price prevailing at Chicago, when the food control act became a law. Evidently, Congress did not expect farmers to raise a bumper crop for the legally guaranteed price, but depended upon the President for a more accurate determination of that price. The farmers also, (about to market their 1917 crop and fearing that the price would fall) voiced their anxiety to the President in behalf of a minimum price which should apply to the present crop.

The President saw the necessity for such a step, and sought measures to make it a reality.

On August 24 then (several days after the appointment of the Food Administrator), President Wilson announced the appointment of a committee to determine a fair price at which wheat should be purchased by the Government. This Committee on prices included the following names: :32 $^{2}$

Harry A. Garfield, President of the Williams College, Williamstown, Mass.

Charles J. Barrett, Union City, Ga.

William N. Doak, Roanoke, Va. Vice-President of the Brotherhood of Railway Trainmen.

32 Cf. Multigraph Copy of U. S. Food Administration, Minutes of the Price-Fixing Committee, p. 3. It is to be noted that Mr. Hoover took no part in the deliberations of this Committee, and expressly wished the President to make known to the public his non-interference. Cf. "Book of Information," U. S. Grain Corporation, Aug. 23, 1919, p. 12. 
Eugene E. Funk, Bloomington, Ill. President of National Corn Association.

Edward F. Ladd, Fargo, N. D., President of North Dakota Agricultural College.

R. Goodwin Rett, Charleston, S. C., Secretary of National Council of Farmers' Cooperative Association.

James W. Sullivan, Brooklyn, N. Y., American Federation of Labor.

L. J. Tabor, Barnsville, O., Master of Ohio State Grange.

Frank Taussig, Chairman of Federal Tariff Commission.

Theodore N. Vail, New York City, President of New England Telephone and Telegraph Co.

Henry J. Waters, Manhattan, President of Kansás State Agricultural College.

These men met at Washington, D. C. on August 20, 1917 and after being addressed by Mr. Hoover, set to work to outline the problem for fixing a "fair price" for wheat. Among the factors drawn up for consideration were the following:

" 1 . Welfare of the industrial population as affected by the cost of bread.

"2. The effect of high wheat prices upon the cattle raising and dairy industries as the result of reduced corn acreage and the high prices of feeds.

"3. The relation of American prices to the world condition and the needs of our Allies.

"4. The relation of the general policy to the changed conditions at the end of the war.

" 5 . The relation of the 1917 wheat to the production prices and acreage of the 1918 wheat crop."

The Committee, composed of men whose interests were widely different and whose experience of price-fixing was little, attacked the problem in the most direct manner. Time was not available for any minute search into costs and profits at every move of production. A price satisfactory to the agricultural interests must be selected, and 
with this purpose in view, it was almost certain that the Committee could account for its existence by fixing the price high enough.

But what should this price be? Representatives of the farmers lost no time in placing before the Committee the absolute necessity of a price as high as $\$ 2.50$ per bushel. The farmers, they averred, had long since been imposed upon, and now when their cooperation was of supreme importance they should not be antagonized by any unfairness. Mr. Henry J. Waters, president of Kansas State Agricultural College, in his paper read before the Committee stated that if the price of wheat for the present season was not high enough, other products of the farm, forest and factory would have to be correspondingly lowered or the farmer would feel that special tax had been levied upon him for the benefit of the rest of mankind. ${ }^{33}$

Other represented interests, while not combined to oppose a high price, saw the problem from the consumers view-point, and emphasized the hardships that would result from a high price for such prime necessities as wheat and flour.

Little satisfaction could be gained from consulting statistics on cost. Estimates ranging from $\$ 1.41$ per bushel (thus Professor G. E. Call of the Kansas State College) to $\$ 3.00$ (thus Mr. I. M. Hagen, Commissioner of Agriculture in North Dakota) were not calculated to bring the Comittee to a unanimous opinion.*

On August 28th, the committee, after hearing the arguments of various members, decided to arrive at a price by ballot. Three formal ballots were taken, each of which returned the following result: four for $\$ 2.50$ wheat; one for $\$ 2.30$; two for $\$ 2.25$; two for $\$ 2.10$, two for $\$ 1.84$. Informal ballots were then taken upon the following prices: $\$ 2.15 ; \$ 2.20 ; \$ 2.25 ; \$ 2.30$. On

33 Ibid.

These differences in costs may be explained by taking into consideration the relative productivity of the land, differences in labor costs, and methods of cultivation. 
August 30th, the Committee finally adopted the price of $\$ 2.20$ per bushel for No. 1 Northern spring wheat at Chicago. After reporting this price to the President, it was immediately announced to the country. It will be observed that this price was a compromise between the $\$ 1.84$ proposed by the labor representatives and the $\$ 2.50$ advocated by the agricultural interests.

Upon the President's announcement of the $\$ 2.20$ price the Food Administration affirmed its intention "to use every authority given it under the food control act and the control of exports to effect the universality of this fair basis throughout the whole of the 1917 harvest year without change of fluctuation."

The difference in viewpoint is at once seen between the policies of the legislative and executive branches of the Government. Congress provided a minimum price for the 1918 wheat crop; the Food Administration adopted a definite "fair price" for the 1917 crop. The former was not to be effective for nearly a year, or until July 1, 1918; the latter was effective from its announcement. The former was framed as an inducement to the producer; the latter was proposed to protect both the consumer and the producer.

Turning our attention now, from these preliminary considerations, we shall briefly outline the methods adopted by the Food Administration to maintain the guaranteed minimum despite factors operating for its increase or decrease.

The first step had already been taken before the government price had been announced. It was the proclamation issued by President Wilson on August 14, 1917 which required all stores and distributers of wheat and rye as well as persons manufacturing products of wheat and rye to procure licenses before September 1 . The Food Administration had, a short time before explained its plan to a representative conference of 100 of the country's wheat dealers and received from them the assurance of support. The object of the Administration, 
at the outset, was to elicit the voluntary cooperation of these men, and to depend as little as possible on the sanction of the law.

General regulations applicable to all licenses became effective on November 1,1917 . These general regulations included the furnishing of reports, inspection of records, prohibition of unreasonable profits, prohibition of resales within the same trade, and the prohibition of speculation. In addition to these general regulations from time to time, others more specific were issued. These specific rules determined the miller's profits, prices, and differentals. The license of any miller who engaged in unfair practice could be revoked by the Food Administration. By means of this devise the government could exercise indirect control over millers and grain dealers.

Although a definite price ( $\$ 2.20$ per bushel) had been fixed, it must not be supposed that this price was the same for every elevator in the country. It would be manifestly unfair to compel two elevators situated at unequal distances from a primary market, to pay the same price for each bushel of wheat. The guaranteed price must be added to, in order to provide for transportation costs from the grain elevator to the market. In fact, there was nothing in the food control act, nor in the Food Administration's regulations to prevent millers from paying a higher price than the minimum for wheat. It is natural to assume also, that millers would be willing to pay a higher price and that farmers would be nothing loath to accept it. In view of these considerations, how did the Food Administration effect the universality of the "fair price?"

Two methods were used: the license system and the establishment of the United States Grain Corporation. The license system at this period was little more than a form. It contained great possibilities for close supervision which, were but vaguely seen. Licensees could and did purchase wheat at higher prices than that fixed by the 
government. Such action was not legally wrong; it was simply an indication of unwillingness to cooperate with the Food Administration. With this loophole in the license system it was necessary to devise a more certain plan of effecting the guaranteed minimum. Thus, was established the United States Grain Corporation.

This corporation, headed by some of the country's best wheat exports, was organized on September 4, 1917 under the laws of Delaware with a capital stock of $\$ 50,000,000$. The country was divided into fourteen zones, each of which had a representative agent of the Grain Corporation whose function was to buy wheat at the respective terminal, and distribute it among the various mills of the territory on the basis of their average capacity.

The work of this corporation was to buy all the available wheat and rye surplus grown in America in 1917 and 1918* It determined the local prices for wheat at each of the 18,000 elevator points, adjusted thousands of complaints, organized the gathering of statistics, inspected the reports handed in monthly by the licensed millers, solved disagreements in the trade and dealt with the purchasing agent of the Allies.

The two chief functions of the United States Grain Corporation were (1) the purchase of wheat for the United States, and (2) the controlling of the license system. The Food administration had limited the right of the millers to store wheat and flour to a period not exceeding 30 days. Trading in futures, the ordinary means by which much of the country's grain trade is handled, was prohibited during the war. It was necessary to provide some means for the distribution of wheat to take the place of ordinary market speculation. The machinery evolved by the Food Administration for this purpose was the Grain Corporation.

The $\$ 2.20$ per bushel price provided for by the Lever

* The Grain Corporation continued its activities for two years after the termination of the War. 
Act was a minimum price, which might be raised, and most likely would be raised, by the President for the next year's crop. During the early months of the year 1918 many attempts were made in Congress to increase the price of wheat to $\$ 2.50$ or $\$ 2.75$ a bushel. Senator Gore introduced a bill to increase the price to $\$ 2.50$ per bushel, stressing the dilemma that either the price of wheat must be raised or the general level of other prices must be lowered. The dilemma was stated by the Senator thus: "If the price fixed by the Government for 1918 is high enough, then the price for 1917 was too high. I say this because the cost of producing wheat in 1918 was much greater than in 1917.34 The leading agricultural journals were in accord with this effort, and pointed out that the farmers were not receiving a fair price for their wheat in view of the prices of other commodities. The Non-Partisan Leader (St. Paul), the organ of the NonPartisan League argued that "The price of wheat in comparison with the increased cost of farming and the general increase in the cost of living, is too low." 35

Commenting on Senator Gore's Bill, a Montana farmer wrote: "Senator Gore's Bill to make the price of wheat at the farmer's market is the fairest proposition I have yet seen. The farmers did their best to increase their fall wheat acreage with the minimum price of $\$ 2.00$. But our President steps in and shatters our hope of a price that would cover the cost of production. Our crops were bad enough...hundreds of acres were not cut at all... most the farmers are made to sacrifice all they have... while others grow rich." 36 .

The opponents of the Gore Bill, however, argued that if the price of wheat was advanced to $\$ 2.50$ a bushel there would be an increase in the price of flour of no less

34 Senator Gore, The Wheat Farmers' Dilemma, The Forum. p. 26.

35 The Literary Digest, March I6, I918.

36 Outlook, April I0, 1918, p. 572. 
than $\$ 3$ a barrel, which would mean an increase of 25 per cent in bread prices. Should all our people, the opponents asked, be thus imposed upon by the farmer class representing but fifteen per cent of the population.

On February 21, 1918 the President by a proclamation made the 1917 wheat price applicable to the 1918 harvest. By executive order of June 21, 1918 the price of wheat was raised to $\$ 2.26$ per bushel at Chicago, the 6 cent increase was made to off-set the increase in freight rates. ${ }^{37}$

The Food Administration, then announced the following "fair prices" for "basic" wheats at the terminals designated. ${ }^{38}$

Prices of "Basic Wheat" at Terminals for 1918 Crop.

$\begin{array}{lclc}\text { New York } & \$ 2.391 / 2 & \text { Omaha } & \$ 2.18 \\ \text { Philadelphia } & 2.29 & \text { New Orleans } & 2.28 \\ \text { Baltimore } & 2.383 / 4 & \text { Galveston } & 2.28 \\ \text { Newport News } & 2.383 / 4 & \text { Tocoma } & 2.20 \\ \text { Duluth } & 2.221 / 2 & \text { Seattle } & 2.20 \\ \text { Minneapolis } & 2.211 / 2 & \text { Portland } & 2.20 \\ \text { Chicago } & 2.26 & \text { Astoria } & 2.20 \\ \text { St. Louis } & 2.24 & \text { San Francisco } & 2.20 \\ \text { Kansas City } & 2.18 & \text { Los Angeles } & 2.20\end{array}$

Basic Wheat

No. 1 Northern Spring.

" 1 Hard Winter.

" 1 Red Winter.

No. 1 Durum.

" 1 Hard Wheat.

Varieties of wheat other than the "basic" grades were purchased at premiums over or discounts under the above prices. ${ }^{39}$

37 U. S. Dept. of Agriculture, Wheat Prices Guaranteed by Congress, p. 6.

38 Official statement of the Food Administration, Aug. 22, 1918, p. 9 .

39 Ibid, p. 10. 
The premium wheats were as follows.

No. 1. Dark Hard Winter

No. 1. Dark Northern Spring

No. 1. Amber Durum

The "Discount" wheats were as follows.

No.1. Yellow Hard Winter

No. 1. Red Spring

No. 1. Red Walla

No. 1. Red Durum

No. 1. Soft White

No. 1. White Club
Premium

2 cents.

2 cents.

2 cents.

2 cents.

5 cents.

7 cents.

7 cents.

2 cents.

4 cents.

Discounts for other grades than No. 1.

No. 2. Wheat 3 cents under No.1.

No. 3. Wheat 7 cents under No.1.

The government's guarantee, public opinion, and patriotism stimulated the production of wheat. This was demonstrated by the increased acreage under winter wheat. Over 42 million acres of winter wheat and over 22 million acres of spring wheat were planted. ${ }^{40}$ This was an increase of 7 million acres over the prewar averages (1904-14). The normal prewar annual export of wheat from the United States was about, on the average of 10 years preceding the European War, 110 millions bushels. It was estimated that the total export of wheat and flour (in terms of wheat) of the 1918 crop would be about 310 million bushels..1

The export trade was handled by a separate division of the Food Administration called the Wheat Export Company. All orders from the Allied nations came to this division which could regulate the supply of wheat products in accordance with necessity. To a large extent the policy of the Food Administration was to export flour instead of wheat. This recommendation was made by the National Federation of Millers. ${ }^{42}$ Export of wheat

40 Department of Agriculture, Wheat Prices Guaranteed by Congress, 1918, p. 4.

$4 \mathrm{I}$ Ibid, p. 6.

42 Report of r6th Annual Meeting of the Millers, April i2, 1918, p. 7. 
products to countries other than the Allies was handled by the War Trade Board, and required a special license, which was issued by this body only after careful investigation. With such precaution little wheat or flour was exported to countries other than our Allies.

The Allied Governments also realized the advantage of placing their purchases in the hands of a single buyer. Competition between countries and the agents for private concerns would thus be eliminated and a more equitable distribution could be secured. This machinery greatly simplified trade between the United States and the Allies.

On September 2, 1918, the President by proclamation fixed the price of wheat for the crop of 1919 at $\$ 2.26$ per bushel at Chicago, and at the other markets at a corresponding price. The differentials established between the primary markets of the United States were as follows: Kansas City and Omaha.

Duluth \& Minneapolis.

St. Louis.

5 cents less than basic.

New Orleans \& Galveston, Basic 2

Buffalo.

Baltimore \& Philadelphia.

New York.

5 cents less than basic.

In his proclamation, the President stated that he would appoint "a disinterested commission in the spring of 1919, who will secure the facts for me by that time disclosed as the prewar average prices of wheat, of labor, and of supply costs as a basis, and from that information I shall determine whether there should be an increase in price above the present level... I find a great conflict of opinion among various sections of the country as to the price that should be named as a minimum guaranty. 'It must be obvious to all, however that the factors that make for increased or decreased cost of production of next year's harvest can not be determined until the near approach of the harvest"43

43 Official Statement of the Food Administration, Sept. 28, p. 2. 
Criticism was again voiced against the fixed price of wheat in the hopes that the price for 1919 wheat would be raised. It must be remembered that when we embarked into the conflict in 1917, there was great uncertainty as to its duration. As the struggle continued, the prevalent opinion in the United States and also in Europe held that the backbone of Germany's defence was nearly broken and that it was only a question of days when Germany would be compelled to quit. Prescinding from the propaganda element which doubtless fostered this opinion, it must be said that it was probable enough to enter into the calculations of the 1919 wheat price. The Government's wheat guaranty given for a year in advance, if fixed at a high price might entail the loss of millions of dollars if peace was declared before the middle of 1920.*4 The Food Administrator estimated the government "Would lose from $\$ 300,000,000$ to $\$ 500,000,000$ on this wheat guaranty if peace arrives before the 1918 harvest is marketed." 45 Should peace be declared, Europe, with its tonnage released from the service of war would seek wheat from the large stores then in the Southern Hemisphere, for prices would be much cheaper there than in the United States. Despite the possibility, however, the production of wheat must be stimulated in any contingency by a fair price.

The \$2.26 price, however, was retained. In defence, the President explained that a higher price would dislocate the present wage levels and thus create an industrial unrest, which would be harmful to the country.

The price of wheat had been kept relatively lower than the price of other foods. The effect of this was to increase the use of wheat, regardless of the Food Administration's appeals. By February 1918, an unduly large part of the year's crop had been consumed.

On January 28, 1918, the " $50-50$ " rule went into effect, requiring the purchase of an equal amount of other

44 Ibid, p. 2.

45 Bulletin, No. 10, p. 9, U. S. Food Administration. 
cereals with wheat flour. On February 3, bakers were required to mix 5 per cent of other cereals with wheat flour; by February 24, the substitute was increased to 20 per cent, and in April, reached 25 per cent. These baking regulations, as well as the " $50-50$ " rule were in force, until August 28, when the bakers were placed on an 80 per cent wheat and 20 per cent substitute basis. All regulations requiring wheat substitutes were suspended on November $14 .^{46}$

The Food Administration attempted, as has been seen, to stablize the price of wheat. That it accomplished this, seems clear from the wheat quotations in any terminal market from August 30, 1917, when the "fair price" was announced, until after the signing of the armistice in November, 1918. The price of No. 2 Red Winter wheat in Chicago, for instance, varied only three fourths of a cent from September 1917, to the end of June 1918. ${ }^{47}$

\section{FLOUR.}

The natural relation between wheat and flour acts as an automatic adjustment on the market price of the latter, so that the price of flour rises or falls with the price of wheat. Following the lead of wheat, the price of flour rose quite steadily from August 1914 to February 1915, when a slight drop took place. In May of the same year flour prices took a great ascent, partly because of an increase in European demand and partly because of the periodic rise at this time of the year. Soon afterward, owing to the opening up of the Dardanelles the price of wheat fell and was followed by a corresponding drop in the price of flour. European demand had decreased temporarily in the hope of being able to purchase at lower prices. During the remainder of 1915 and almost throughout 1916, flour prices remained stable.

46 Official Statement of the United States Food Administration, Dec. I, I918, p. 7.

47 Wheat \& Wheat Products, War Industries Bulletin No. 10, p. 6. 
Toward the latter part of the year, 1916, however, an acute shortage in the wheat supply was felt, which caused a rise in the prices of both wheat and flour. With the declaration of war by the United States, the price rose from $\$ 11.62$ a barrel in April to $\$ 14.88$ in May, and fell to $\$ 13.07$ in August. This decline was occasioned by the apprehension of Government control. In September after Government control had been established, the price dropped to $\$ 11.26$, and in December was found at $\$ 10.00$, around which price it remained till the first half of 1918.

That the abnormal increase in the price of flour was not entirely due to shortage of wheat may be seen from the report of the Federal Trade Commission, in its investigation on the profits of millers and jobbers. It found that jobbers had increased the average gross profit per barrel (of car lot) from 28 cents in 1916 to 54.5 cents in the first half of 1917; that expenses exclusive of salaries, increased only from 10 cents to 13.5 cents; that net profits showed an increase from 18 cents to 41 cents and that the rate of profit on investment showed an increase of from 31.5 per cent to 60.7 per cent. ${ }^{48}$ It was likewise found that the profits of millers had increased from 11 cents per barrel in 1912-13 to 52 cents per barrel in 1916-17.

These conditions seemed to point to the need for Government regulation. The Food Administration took the situation in hand and under the license system devised a method of not only controlling the wheat market but also the flour market. Congress had not fixed a price for flour, and the Food Administration took the stand that it had no authority to fix prices for the same. It exercised control, nevertheless, by means of the license system. Control of the flour trade was given over to the Milling Division of the Food Administration. This Division divided the country into nine zones and over each zone placed a representative agent. Millers and dis-

48 Report of the Federal Trade Commission on Milling \& Jobbing, 1918, p. 7. 
tributers were required by a proclamation of the President's on August 14, 1917 to procure licenses in order to do business. The voluntary agreements made in regard to the wheat trade also applied to the milling industry. The regulations in force for the wheat trade were likewise applied to the flour trade. The only addition was a limitation of 25 cents profit on each barrel of flour.

Considerable difficulty was experienced by the Food Administration in arriving at a satisfactory cost method. In the monthly reports that each miller must submit, the cost of production must be set forth as a basis for the determining of profits. In its report, the Federal Trade Commission objected to the cost of production plus the allowed profit on the ground that it offered a temptation to falsify reports. It was to be expected that the Food Administration could not examine and verify each report from thousands of millers throughout the country. The Federal Trade Commission had found evidence of padded reports, and the establishment of jobbing departments in some mills in order to get both a miller's and a jobber's profit on their product.

These difficulties probably led to a change of policy in the Spring of 1918. Voluntary agreements were cancelled. ${ }^{49}$ The Milling Division of the Food Administration went out of existence on June 30, 1918. "Fair price" schedules then, were sent to each one of the 8,500 mills in the country: These schedules relieved the mills of the trouble of calculating prices. The plan of control included: (a) price of bulk flour and feeds. at every producing point in the United States. (b) The price of flour was based on the Government guaranteed fair price for wheat. (c) These prices were on the basis of carload sales, bulk at mill; the "fair price" list ranged from $\$ 10.65$ per barrel at Boston to $\$ 9.75$ at Salem, Oregon. ${ }^{50}$

The bulk flour price for each mill was arrived at by taking the "fair price of wheat at the nearest terminal,

49 Official Statement of the Food Administration, Sept. I2, I9I8.

p. 7 .

50 Ibid., p. II. 
plus freight to the mill plus $\$ 1.10$, called a conversion charge (to cover the cost of milling and profit), minus the feed return." ${ }^{51}$. The miller was guided in determining the price of any sale by a table of "maximum permissable margins" which showed him the amount he could add on certain sales. A table like the following was made out.

Method of calculating maximum, delivered fair price flour per barrel.

(a) Maximum fair price bulk mill as per schedule No. $000 \ldots \ldots \ldots \ldots \ldots \ldots \ldots \ldots 10.50$

(b) Maximum differential, if any on sale of class $\mathrm{C}^{*} \ldots \ldots \ldots \ldots \ldots \ldots \ldots \ldots \ldots \ldots \ldots \ldots \ldots \ldots . .25$

(c) Freight charge (including freight tax) ... .40

(d) Cost of sacks $\ldots \ldots \ldots \ldots \ldots \ldots \ldots \ldots \ldots, \quad .60$

Total ........................ \$11.75

All sales contracts must be copied and sent with the fair price for the particular mill to the Food Administration. These new regulations simplified the flour control problem and protected buyers against the póssibility of unjust prices.

On January 1, 1918 the quantity of wheat which millers were allowed to use for a barrel of flour was reduced from 285 pounds to 264 pounds. Two months later, only one grade of flour was permitted to be milled. On September 1,1918 , regulations providing for the preparation and marketing of a mixed flour called "Victory Flour" were enforced. The purpose of these regulations was to place the country on a mixed flour basis, without making it necessary for retailers to make combination sales of flour and substitutes. Mixed Wheat, and barley flour was in the proportion of 4 pounds of wheat to 1 pound of barley flour. Mixed wheat and corn flour was to be sold in proportion of 4 pounds of wheat flour to 1 pound of corn flour. Wheat, barley, and corn flour were mixed in proportions of 8 pounds of wheat flour to 1

51 Government Control over Prices, Bull. No. 3, p. 7 I.

* Class C included sales of consigned flour to wholesale dealers from cars or docks; in carload lots (not delivered) 25 cents per barrel over basis. 
pound of barley and 1 pound of corn flour. With the enforcement of these regulations the " $50-50 "$ rule was superceded. ${ }^{52}$

The Presidential Proclamation of October 1, 1917, before referred to applied also wholesalers and retailers. Profits were controlled by means of margins established by the Food Administration. The general rule was that profits should not exceed a greater percentage than that of the prewar period. To prevent resales to wholesalers, flour was required to be kept moving in a direct line and without any unreasonable delays. Hoarding and speculation were prevented by limiting licensees to a 30 days supply.

\section{BREAD.}

By the Presidential Proclamation of November 7, 1917, bakers, and all "firms, corporations and associations, who manufacture for sale bread in any form, cake, crackers, biscuits, pastry or other bakery products (excepting, however those already licensed and those whose consumption of any flour and meal in the manufacture of such is, in the aggregate, less than 10 barrels a month) are hereby required to procure a license on or before February 4, 1918." 53 This regulation included hotels, restaurants, and clubs which served bread or other bakery products of their own baking.

Another proclamation dated January 30, 1918 was worded in the same manner but extended the license regulation to those dealers whose monthly consumption was 3 barrels or over. ${ }^{54}$

Bakers using less than a barrel a month could obtain a license and subject themselves to the same regulations as those who were included in the license proclamation. By doing such, these bakers were enabled to purchase wheat flour on the basis of one pound for every three

52 Official Statement of Food Administration, Sept. 12, 1918, p. 5. 53 Proclamations and Executive Orders by the President Under the Food Control Act, 1918, p. 8.

54 Ibid., p. 13. 
pounds of wheat substitutes.

In its general information to bakers the Food Administration announced that it had no intention of fixing prices at which bakery products must be sold, but required that the prices of these articles be fair and that the profits of the trade be reasonable.

The Baking Division of the Food Administration took the initial step in control when it ordered the standardization of the baker's loaf. Previous to this time there had been as many as 38 different weights to bread loaves. ${ }^{55}$ Now the minimum bread loaf was to be one pound; loaves of one and a half, two and four pounds were also allowed. The object of this regulation was to reduce the waste of flour and to limit the use of sugar and lard." 56

No more than three pounds of sugar could be used with each barrel of flour. Before this regulation was made, the average amount of sugar to a barrel of flour had been 6 pounds. The reduction of 3 pounds of sugar on each barrel would effect a saving of $100,000,000$ pounds of sugar in a year.

Shortening was restricted to 2 pounds per barrel, whereas previously 6 pounds could be used. The lard saved by this regulation would amount to $100,000,000$ pounds a year.

During August 1918, no licensed baker could use in the manufacture of his products except bread and rolls more than 70 per cent of the amount of wheat used the previous month. Wheat flour substitutes were defined as bran, shorts, and middlings, corn flour, corn meal, hominy, corn grits, barley flour, oats, oatmeal, rice, rice flour potato flour and other products of a similar nature. Rye flour was named as a partial substitute of wheat on the following basis: One fifth of the wheat flour substitutes used in any mixture may be rye flour and rye meal.

To prevent waste in wheat flour and its substitutes no baker was allowed to accept unsold bakery products, or

55 The United States Food Administration, Bull. No. II, p. 2.

56 Ibid., p. 3 . 
take them in exchange for fresher supplies. The "cash and carry system," as a means of reducing the cost charges and the ultimate price to the consumer was recommended by the Food Administration. No baker was allowed to kecp on hand stocks of wheat, flour, sugar or shortening in excess of the reasonable requirements of his business for over 60 days.

The Baking division prescribed as a patriotic measure the making and sale of products with 20 per cent or more of wheat flour substitutes called "Victory Bread," "Victory Cake," etc. All Victory products must contain this amount of wheat substitutes, with the exception of bread and rolls the requirement for which was 25 per cent.

There was a popular demand during the early stages of the bread control for a five cent loaf. Such a loaf was not considered economical by the Food Administration, as it would cost just as much to deliver as a larger loaf, and would have relatively lesser weight. ${ }^{57}$

Public eating places were required to serve no more than 2 ounces of any kind of wheat bread or rolls, nor more than 4 ounces of muffins. corn bread, or biscuits to any person. The maximum weight for rolls was 2 ounces. ${ }^{58}$ Simultaneously with all these regulations, food conservation measures, such as wheatless meals and wheatless days were urged upon the public. Attractive posters met the public eye at every street corner, in every street car, in public buildings and everywhere demanded attention. Four minute speakers travelled the country and addressed multitudes of workers during the noon hour, and in halls and assemblies at night. The services of policemen were enlisted to make a house to house canvass among the housewives to obtain pledges of conservation. The necessity of retrenchment was the subject of several letters from the Food Administrator to the church-going population. These letters were read from nearly every pulpit in the United States.

The average retail price of bread rose from its custom-

57 Food Administration, Bull. 10, p. 4.

58 Food Administration, Bull. II, p. 7 . 
ary level of 5 cents per loaf to 6.4 cent on November 15 , 1914. In November 1915, the price advanced to 7 cents; in 1916. to 8.4 cents; in 1917, to 9 cents; and in 1918 to 9.8 cents. $^{59}$ Government control seems to have curbed the price of bread to some extent. Compared with the price level of the six months preceding Government control, there was but a three per cent rise in the price of bread during the war. After the regulation of the Food Administration was removed about January 1, 1919, the price of bread advanced to 8.5 cents, or an increase of 11 per cent over its prewar average.

On September 20,1918, retail prices for bread were established by the Baking Division. The maximum price for "cash and carry," or credit and delivery was 10 cents for one pound loaf and $\mathbf{1 5}$ cents for one pound and a half loaf."60

59 U. S. Food Administration, Bull. No. 11, p. 7.

60 Official Statement of Food Administration, Oct. I, 1918, p. I7. 


\section{CHAPTER IV.}

\section{CONTROL OF SUGAR.}

Of all the problems confronting the Food Administration, that of the sugar shortage of 1917 and 1918, was perhaps the most complicated. In order to understand the world sugar situation during this period, it is necessary to bear in mind four factors, each of which contributed in a measure to produce and at the same time complicate the situation.

First, we must remember that the United States, Canada and England were sugar importing countries before the war, while France and Italy were very nearly self-supporting. Secondly, that the main sources of supplies to importing countries were (1) Germany and neighboring powers. (2) The West Indies, (3) The East Indies. Thirdly, that the German sources were entirely cut off; though she still had access to sugar of the surrounding countries. Fourthly, the loss of tonnage produced a shortage of vessels, which rendered long hauls almost impossible.

The best fields of Belgium, France, Germany and Austria, suffered from the ravages of war. Workmen were taken from the sugar factories and the production of sugar was seriously curtailed. European beet sugar production including that of Germany decreased from $8,243,165$ tons in $1913-14$ to $3,849,000$ tons in 1917-18. On the other hand, the total cane sugar production increased from $9,839,919$ tons to $12,070,000$ tons during the same period. ${ }^{61}$.

6I New York Coffee \& Sugar Exchange, Dec. 7, 1917.

56 
The following table shows the estimates of the world's sugar crop. ${ }^{62}$

Total Cane Sugar production, (Willet \& Gray Estimated)
1917-18
1916-17
1915-16
$12,070,000$
$11,233,794$
$10,385,523$

European Beet Sugar production. (Willet \& Gray Estimated)
$3,849,000$
$4,555,407$
$5,209,233$

U. S. Beet Sugar production (Willet \& Gray Estimated) 975,000 734,577

$\mathbf{7 7 9 , 7 5 6}$

Grand total of cane and beet sugar

\begin{tabular}{lr}
$16,794,000$ & $16,523,000$ \\
$1914-15$ & $1913-14$. \\
$10,216,654$ & $9,839,919$ \\
$7,583,215$ & $8,243,165$ \\
646,257 & 655,298 \\
\hline $18,446,126$ & $18,732,382$
\end{tabular}

As will be seen from the table given above, the world sugar situation was not due entirely to decreased production. The sugar shortage did not begin to exist till the early part of 1917. If we compare the estimates of the total production for the two preceding years with that for 1917-18, we are forced to conclude that despite decreased production in Europe, no appreciable effect was felt in the world supply.

On the other hand, sugar consumption during the war might well be expected to have increased. It has been found that soldiers under the strain and severity of warfare and encampment have an abnormal craving for sweets. To what extent this craving was appeased we can not determine exactly, but in general it may be assumed that an increased consumption of sugar would obtain among soldiers. It is to be expected likewise that sugar would be used more extensively also by those engaged in other laborious occupations. Thus, in the United States during the first six months of 1917, the

62 Ibid., p. 6. 
consumption of sugar increased 10.7 per cent; $;^{63}$ the increase for the entire year over the preceding year was 5 per cent. This increase in consumption, was due in part to a great activity in the home canning of fruits. and vegetables in accordance with the propaganda of the Food Administration, and in part also to the fact that there had been sugar left over from the 1916 crop. $^{64}$

The per capital consumption of sugar in the United States during the years 1910-1917 was as follows : ${ }^{65}$

$\begin{array}{llllll}1910 & 81.6 & \text { pounds } & 1914 & 84.29 & \text { pounds } \\ 1911 & 79.2 & " & 1915 & 83.83 & \text { " } \\ 1912 & 81.3 & " & 1916 & 79.34 & " \\ 1913 & 85.4 & " & 1917 & 84.35 & \end{array}$

We can arrive at the consumption figures of the Allies during this period by knowing first of all how much sugar each country produced, and finding how much was imported from other countries. Great Britain before the war produced no sugar herself, but imported about 80 per cent of her requirements from Germany and Austria; cut off from this source of supply, she early entered the Cuban market with orders for large quantities. France produced about 228.000 tons of beet sugar in 1916-17, while Belgium's crop was about 149,000 tons. ${ }^{66}$ The following tables shows the imports into the United Kingdom, France, and Italy from the United States and Cuba.

Exports of Sugar (mostly refined) from United States to Allied Countries ; 1914-17.

\begin{tabular}{|c|c|c|c|c|}
\hline & 1914 & 1915 & 1916 & $\begin{array}{r}1917 \\
42534\end{array}$ \\
\hline United Kingdom & 141,602 & 211,346 & 187,803 & 42,534 \\
\hline France & 978 & 210,648 & 275,644 & 232,72 \\
\hline Italy & & & 32,830 & 20,96 \\
\hline & 142,580 & 421,994 & 496,277 & 06 ? \\
\hline
\end{tabular}

63 Daily Sugar Journal, Willet \& Gray, July 5, 1917, p. 5.

64 Ibid., Jan. 10, 1917, p. 6.

65 Ibid., Jan. Io, I9I7, p. 6.

66 Official Statement of the Food Administration, Dec. I, I918, p. I0. 
Exports of Sugar (mostly raw) from Cuba to Allied Countries 1914-17.

\begin{tabular}{|c|c|c|c|c|c|}
\hline & & 1914 & 1915 & $\begin{array}{c}1916 \\
610909\end{array}$ & \\
\hline United & Kingdom & 293,290 & 402,915 & 619,992 & \\
\hline $\begin{array}{l}\text { France } \\
\text { Italy }\end{array}$ & & 37,636 & 6,811 & $\begin{array}{r}120,196 \\
6,285\end{array}$ & \\
\hline & & 0,926 & 409,716 & 746,473 & 8 \\
\hline
\end{tabular}

Early in 1917, the sugar shortage began to be felt in Europe.* By necessity, these countries were placed on a

* In Great Britain, for example, the sugar situation had assumed such gravity that in January, 1916, the Royal Commission, in order to check consumption advanced the price from $3^{\mathrm{T}} / 2 \mathrm{~d}$. per pound retail to $4 \mathrm{~d}$., and in February issued an appeal for conservation to the public. Not finding any decrease in consumption the Government at the end of February raised the price again to $43 / 4$ d.

Such efforts were only in part successful. The consumption in 1916 was but 15 per cent less than that of 1915 and 19 per cent less than in 1914. (Financial and Commercial Review, Jan. 19, 1917, p. 13). A system of rationing which allowed to the manufacturer and confectioner all the sugar he needed, while the consumer was obliged to go unsatisfied resulted in great inconvenience but little retrenchment. (Manchester Guardian, Sept. 2, I916, p. 5). Re. fined sugar, whether that imported by the Government or that turned out by British refiners, was apportioned to wholesale dealers in proportion to the amount of their purchasc in 19I5. The wholesalers distributed to the retailers on the same principle, and the latter in turn were expected to sell to their customers as equitably as possible. This system of apportionment was productive of much unfairness, for well-to-do customers, in spite of regulations succeeded in getting more than their relative share of the allowance. (New Stateman, March 10, I9I7, p. 533). These defects were brought home to the government by numerous complaints, and early in 1916 remedies were sought.

On January II, I9I7, an order issued by the Food Controller prescribed that no manufacturer of sugar confectionery might use more than 50 per cent of the sugar used by him during corresponding periods of I9I5. Two months later this ration was reduced to 40 per cent, and later to 25 per cent of the amounts used in 1915. (Defense of the Realm Manual 34 ed., p. 244,421).

Many retail grocers adopted the course of supplying sugar only to those persons who bought other specific commodities. Despite the government's insistence that the fixed price be adhered to, the public found that these conditioned sales were just as expensive as if the grocers were permitted to sell sugar for what it would fetch. Since no definite rationing system for consumers was adopted consumers did not see why retailers should not sell them whatever amount they asked for. It became neccssary at last to issue sugar registration cards, which might be depositec with any retailer. These registration cards entitled each holder to a weekly allowance of sugar proportionate to the general stocks in Great Britain at the time.

The amount of sugar allowed to each person in England was about two pounds per month. France was compelled to reduce her sugar rations to only a little over one pound per month. 
sugar ration basis. Our exports of refined sugars to the Allies decreased from 496,277 tons in 1916 to 292,222 tons in 1917-a decrease that was partly compensated for by importations of Cuban raws. ${ }^{67}$ From the above table, it may be seen that the total amount of sugar, raw and refined, exported from the United States and Cuba, to the United Kingdom, France and Italy in 1916 was $1,242,740$ tons as against 1,150,320 tons in 1917. These same countries had need of only 473,506 tons in 1916. The difference between the amount for 1917 and that of 1914 indicates the dependence of these countries in 1917 upon Cuban and American sugars.

Exports from Cuba in 1912-13 to the United States were 85 per cent of her total production while Great Britain received 11 per cent; but by 1916 the situation had so changed that 26 per cent of the Island's total production of sugar went to the United Kingdom and the continent and only 70 per cent came to the United States. ${ }^{88}$

Another cause of the American and European sugar shortage in 1917 was the great destruction of tonnage, and the consequent lack of shipping facilities to transport sugar from Java. Previous to the war, the United States obtained large quantities of raw sugar from the Dutch East Indies, and in certain prewar years had imported as much as 400,000 tons from that source. From August, 1914, this country imported practically no raw sugar from there. Great Britain likewise imported no raw sugar from Java during this period. The shortage might certainly have been relieved had ships been available to make the long haul from Java. It was estimated that in December 1917, Java alone had over 900,000 tons of sugar available for export. ${ }^{69}$ The United States Food Administration endeavored to obtain shipping to send there, but the Shipping Board could not provide ships for this purpose for obviously it would have been detri-

67 Hearings on Sugar Shortage, Dec. I917, p. 1036.

68 Conditions in the Sugar Market, I9I7, American Refining Co., p. I3.

69 Hearings on the Shortage of Sugar, p. II. 
mental to the war aims of the country to send ships to Java when there was insufficient tonnage for more essential purposes.

In his testimony before the Senate Sub-committee investigation of the shortage of sugar, Mr. Hoover declared that the problem was fundamentally one of tonnage. ${ }^{70}$

Earlier in this chapter mention was made of the increased consumption in the United States especially during the first half of the year 1917. There is reason to believe that much of this consumption was nothing more that hoarding on the part of consumers. During the first three months of the year strikes at the eastern refineries were given publicity by the newspapers; and rumors of famine reacted upon the fears of housewives to such an extent that "future" buying was the order of the day. ${ }^{71}$. The increased consumption in the latter half of the year, was due to the active response of housewives to President Wilson's appeal to "secure the conservation of surpluses of perishable food products." The Food Administration undertook an educational campaign for the conserving of surplus food stocks; newspapers, periodicals and publications aided this propaganda, and indicated ways and means of preserving and canning.

The heavy buying of Cuban raws by the Royal Commissions of Great Britain was accelerated about the middle of 1917 by the introduction of a bill into Congress providing for a repeal of the drawback privilege on sugar. Besides this, an excise tax of $1 / 2$ cent a pound on sugar for export as well as for domestic consumption was also advocated. Enacted as law, these recommendations would have meant an increase in the export price of refined sugar of over $11 / 2$ cents per pound. The Allied countries, seeking the cheapest market, were thus forced into competition with the United States for Cuban cane. A public statement issued by the Food Administration

70 Ibid., pp. 549-705.

7 Conditions in the Sugar Market in 1917. American Ref. Co., 1917, p. 15. 
observed the effect of this contemplated procedure by Congress to be a "viólent speculation in Cuban sugars," that caused the price to advance from $\$ 6.77$ (per hundred lbs.) in the last week in June to $\$ 7.77$ the first week in August." ${ }^{2}$

It was to be expected that these causes of the sugar shortage would send prices skyward. The duty-paid, net cash price for raw sugar at New York increased steadily, with hardly a drop, from $\$ 5.89$ per hundred pounds on June 1, 1917 to $\$ 7.52$ per hundred pounds on August 7, 1917. The following table shows the changes in the price of raw sugar for the years 1913-1917 during the period of June 1 to August 7.

Prices of Raw Sugar in Cents (duty paid at New York).

$\begin{array}{llllll} & 1913 & 1914 & 1915 & 1916 & 1917 \\ \text { June 1 } & 3.33 & 3.38 & 4.95 & 6.33 & 5.89 \\ \text { July 1 } & 3.48 & 3.32 & 4.95 & 6.40 & 6.52 \\ \text { August 1 } & 3.65 & 3.45 & 4.64 & 6.21 & 6.52 \\ \text { August 7 } & 3.73 & 3.26 & 4.33 & 5.75 & 7.52\end{array}$

On August 10, Mr. Hoover was appointed Food Administrator. Acting under the powers conferred by the Food Control Bill, he soon organized the Sugar Division Administration over which he placed Mr. George M. Ralph. Not possessing the power to fix the price of sugar directly, the Food Administration relied upon the license system to gain control of the sugar industry. In accordance with Presidential Proclamation all importers, manufacturers and refiners of sugar, sugar-sirups and molasses were obliged to secure licenses in order to carry on their business..$^{73}$ By October 1, virtually the entire sugar industry was brought under control. Another important step was the suspension of all trading in sugar futures on the New York Coffee and Sugar Exchange. A third step was the extension of the export control of the

72 Official Statement of the U. S. Food Administration, Sept. 30, 1917, p. 5 .

73 Proclamations and Executive Orders by the President. U. S. Food Administration, 1918, pp. 6 \& 7 . 
War Trade Board to include sugar; permission for each exportation of sugar was required by this Board.

The rise in the price of Cuban sugar due to the causes already noted, produced a parallel rise in domestic beet sugars. Early in September beet sugar was sold in New York at $81 / 4$ cents per pound wholesale, and brought from 12 to 16 cents per pound retail. At the request of Mr. Hoover, a representative body of beet sugar producers met in Washington during the week ending August 26 , to come to an agreement upon the price of beet sugar. After much discussion, the representatives of the beet industry agreed with the Food Administration to charge not more than $\$ 7.25$ per 100 pounds, New York's basis, for their entire 1917 output. An agreement was also reached with the Louisiana producers, limiting the price of the product to $\$ 7.80$ per hundred pounds..$^{74}$

In October, 1917, the sugar refiners came to Washington at the request of Mr. Hoover, for the purpose of agreeing upon a definite margin of profit. As was the case with many of these voluntary agreements between the Food Administration and the trade, much discussion over costs real and imaginary took place. Some refiners would place the margin as high as $\$ 1.60$ per hundred pounds, but these, it appears, were in the weak minority. The figure was finally placed at $\$ 1.30$ per hundred pounds. ${ }^{75}$

- Another important step in the process of sugar control was the establishment, on September 21, 1917, of the International Sugar Committee. The regulation of the domestic beet and cane sugar industry affected less than one half of the entire trade. It would be futile to attempt to stabilize prices without taking into account prices for Cuban cane. Taking advantage of the worldwide shortage and the competitive buying between the United States and the Allies, the Cuban planters had already lifted their prices for the remainder of the 1917 crop. 
In order to deal with this situation more effectively the International Sugar Committee made up of representatives of the United States, England, Italy and Canada was formed. The main purposes of this organization were to purchase from the Cuban growers sugar at uniform and agreed prices; to make allotments of these purchases to the various countries, and also to distribute that portion which had been set aside for the United States among the refiners.

After considerable discussion, the refiners in this country allowed the International Sugar Committee to arrange all purchases for them. The Committee then set about the purchase of the remainder of the 1917 Cuban crop. The Cuban planters held out for $\$ 5.25$ per hundred f. o. b. Cuba, while some of the American representatives, basing their estimation on the cost of production figures for Cuba were unwilling to concede more than $\$ 4.50$ per hundred pounds. Meanwhile the American people were experiencing a sugar famine such as had never before been heard of. On December 24, the differences were finally settled by an agreement whereby three-fourths of, or upon option, the entire new crop was to be sold to the International Committee at $\$ 4.60 \mathrm{fob}$. Cuban ports. ${ }^{76}$ After adding freights, duties and other costs this price was equivalent to about $\$ 6.00$ New York City.

Thus far, it will be seen that three different prices for sugar were fixed: (1) beet sugar was to sell at $\$ 7.25$ per hundred pounds at New York; (2) domestic cane at $\$ 7.70$; while (3) Cuban cane was fixed at $\$ 6.00 \mathrm{New}$ York City plus the refiners margin of $\$ 1.30$ per hundred pounds. It is obvious that these discrepancies in price could not be maintained, despite agreements between the refiners and the Food Administration. The beet sugar industry varied in its cost of production from 2.6 cents per pound to 4.5 per pourid. To limit the profits of these refiners by restricting them to a profit margin would result in a different price of sugar for every factory in

76 Joshua Bernhardt, Government Control of Sugar, 1919, p. I6. 
the country. The consumer would have no benefit from this arrangement, because if a retail groceryman bought part of his sugar at one price and part at another, we can be assured that he would maintain the top price. The beet sugar dealers might have agreed upon a definite price and then pooled their entire output and the costs of distributing it among themselves. Such a method, however, called for an agreement among factories, which could hardly be expected. Moreover, agreements of this kind might possibly come within the Sherman Act forbiding combinations in restraint of trade. These obstacles in the way of a fixed price for beet sugar were also present with regard to cane sugar.

From the testimony of Mr. Spreckels, at the Hearings on the Sugar Shortage it appears that the sugar shortage in the eastern States from October to January, 1917-18 could have been relieved, had Western refiners been willing to part with their surplus. There were approximately 110,000 tons of raw sugar held during this period by the Western Refining Company and the California and Hawaiian Refining Company, which amount was sufficient to provide the Atlantic Coast States for at least a month. The Food Administration had fixed the price of beet sugar at $\$ 7.25$ per hundred pounds at San Francisco, Boston, New York, Philadelphia and New Orleans. As this price, however, made no provision for transportation charges, Western refiners found it more profitable to keep their sugar at home. ${ }^{77}$ In order to move these sugars East, the Food Administration was obliged to raise the price of beet sugars from $\$ 7.25$ to $\$ 8.15$ per hundred pounds to equal that of Louisiana cane sugar.*

Many of the Eastern cities were practically bare of sugar during these months, and people experienced the barren pleasure of knowing that the price of sugar was low, without being able to purchase any.

77 Hearings on the Sugar Shortage, p. 110.

* The $\$ 8.15$ price for beet would be equivalent to $\$ 8.35$ for cane sugar, as the market price for cane sugar is always about 20 cents higher per hundred pounds than that of beet sugar. 
As yet no guaranty of a fixed price had been given to the beet growers. The contracts made by the factories were one-sided and unfair. Their costs had doubled, many had lost money the previous year. Unless a higher price was guaranteed either by the factories or by the Food Administration the beet growers could no longer afford to raise beets. Mass meetings were held (by the beet growers), costs of beet growing and refining were investigated for various states, and resolutions were drawn up and presented to the Food Administration.

The profits made by the refiners in Southern California were enormous. In one instance which is quite representative, the manager and secretary of the Santa Ana Sugar Refining Company testified before the grand jury of Los Angeles County that his refinery represented an investment of $\$ 1,250,000$ and that it had made a net profit for the 1915-16 crop of between $\$ 800,000$ and $\$ 900,000 .^{78}$

It is unnecessary for our purposes to enter into a discussion of these charges. In general, it seems fair to say that the beet growers were getting the worst of the bargain. The basic figure per ton received by the growers over a ten year period was $\$ 4.50$. For the 1916 crop they received this price plus a bonus of $\$ 2.00$ per ton. The Food Administration after some delay finally made agreements with the factories to pay $\$ 10.00$ per ton for beets-an indication that the growers had not been justly treated.

The agreements between the sugar trade and the Government resulted in considerable saving for consumers. While it is impossible to know exactly to what price sugar would have risen without interference, perhaps 25 cents per pound-it is reasonable to think that some reduction resulted. The sugar trade journals were unable to see why the price should be kept so low relative to other food products. The acute shortage in the East would naturally have tended to raise prices in this terri-

78 Ibid., p. 462.-Mr. Hoover seemed unaware of refiners' profits when he fixed the price for beet sugar. 
tory, yet even during the worst periods sugar did not advance to more than 15 or 16 cents per pound, the average price to the consumer of the middle Western states was about nine cents per pound.

The next important step in the evolution of the Sugar control was the creation of the Sugar Equalization Board in July 1918. In order to understand clearly the purpose for which this Board was brought into existence, it will be necessary to trace briefly the price problem that confronted the Food Administration at the beginning of 1918. We have already seen that the Food Administration tried to stimulate the production of sugar beet and cane in the West by granting a raise in the prices to the growers, and that the growers estimating the price as inadequate, were not inclined to plant for the next year's crop. Thereupon. Mr. Hoover appointed local committees in the principal beet-growing and cane-growing states to investigate costs of production with the purpose of finding out a price that would effectually stimulate without resulting in excessive profits.

The Tariff Commission aided the Food Administration in this work by seeking to determine the actual costs for the beet sugar factories. In its recently published bulletin, ${ }^{79}$ the Tariff Commission reports that there was a substantial increase in the prices of all the principal items entering into the production of sugar, that a rise of 200 per cent in the filter cloth would add about $\$ 1.30$ to the cost of a ton of sugar in 1918-19 above the cost in 1917-18, while a 40 per cent increase in wages of factory labor alone would add over $\$ 3$ to the cost of a ton and if the rise extended to agricultural labor, as manifested by the increased cost of beets, the increased cost of a ton of sugar would be over $\$ 12 .{ }^{80}$

From these investigations the Food Administration learned that a price of 9 cents a pound would be sufficient to cover approximately 85 per cent of the production,

79 Refined Sugar, Costs, Prices and Profits, 1920.

80 Costs of Production in the Sugar Industry, Tariff Information Series (39), p. 3I. 
and yield a profit of a cent a pound to the higher cost producers, and that 7.45 cents a pound, the price fixed for the preceding year, would have covered but 30 per cent of the production with a profit of one cent a pound to the higher cost producer of this group.

The minimum price consistent with the aims of the Food Administration was 9 cents a pound. Even this price, it was felt, would compel a number of high cost producers to close their factories. It was hoped, however, that this deficit would be offset by the increased production of the lower cost producers.

The United States Tariff Commission also investigated the costs of the cane producers of Louisiana and found that a price of less than 10 cents for refined sugar would seriously curtail production.

A situation similiar to that in the United States was also found in Hawaii where average costs had advanced from 3.06 cents in 1913-14 to 4.08 cents in 1916-17 and to 5.34 cents in $1917-18^{81}$.

A brief subnitted to the Food Administration by the Cuban Mission, appointed by Governor General Monocal, stated that the price of $\$ 5.06 \mathrm{f}$. o. b. at the north ports of Cuba and $\$ 5.55$ at the south ports would be required to stimulate the production of sugar for the 1918-19 crop. This price, plus duty, freight and other charges would amount to about $\$ 8.54$ per 100 pounds wholesale at New York.

Between the price for the Cuban sugar at New York (\$8.54) and the basic price desired by the Louisiana planters and refiners $(\$ 8.82)$ there was a difference of 28 cents per 100 pounds. ${ }^{82}$ This differential might be distributed either by advancing the price for Cuban cane to that of the American price or by allowing American refiners to purchase sugar at the price the Cubans were willing to accept. Either alternative however, would re-

81 Ibid., p. 35 .

- 82 History of Prices During the War. The War Industries Board, p. 83 . 
sult in enormous profits; in the former case, to the Cuban growers; in the latter, to the American refiners.

How to solve this problem of price complexity and to arrange for more centralized form of distribution was the task facing the Food Administration in the spring of 1918. By June of the same year, Mr. Hoover came to recognize the desirability of a committee to purchase sugars "in Cuba, Peru, Mexico, Java or anywhere else at prices proper to the occasion and to make an average price to our refiners." 83 About this time the shortage became so acute that voluntary conservation could be no longer relied upon. "Therefore, wrote Mr. Hoover to the President, "We must put into effect some form of sugar rationing and a drastic control of distribution. Otherwise we shall have territorial and industrial injustices all over the country. I propose an honor system of cards. An execution of this kind becomes at once expensive for printing alone for 20,000,000 households will cost $\$ 100,000$ a month to say nothing of supervision."

I would propose to solve this by having the corporation undertake the distribution of sugar as a part of its expenses. It seems to me fundamentally sound that the users of a commodity should pay for the cost of its distribution rather than the Government." 84

President Wilson expressed his approval in a letter (June 17, 1918) to Mr. Hoover and authorized ${ }^{85}$ the formation of a corporation to be known as the United States Sugar Equilization Board, Inc.. with a capital stock of $\$ 5,000,000$ owned by the United States.

The object of the board as outlined in a notice of the Food Administration on July 11, 1918 was "to absorb the high peaks of cost in sugar production and to make a small margin on the low cost of certain foreign sugars which may be purchased."

Shortly after its incorporation the Equalization Board bought up all the remainder of the 1917-18 sugar crop

83 Letter to President Wilson, June, 1918.

84 Ibid.

85 Presidential Proclamation, July 8, 1918, Exhibit 16. 
in refiners and sugar mills, still in the country. or in transit. at the old price of 7.35 cents a pound and immediately resold the same to its holders at the new price of 8.8 cents a pound. This transaction eliminated the confusion of "having the new domestic crop at the new price (9 cents a pound) and the old foreign crop at the old price (6.055 a pound for raw and 7.35 for refined) in the market at the same time." ${ }^{86}$

The change in price went into effect on September 6, 1918. The government had made provision for the existing supplies in the hands of the refiners but it remains to be seen what was done regarding the supplies held by wholesalers, jobbers, and retailers. Although presumably their stock on hand was small, nevertheless the Food Administration ordered them to sell their old stocks at the former price. Till the end of the year the Equalization Board became the distributing agent of the refiners, selling sugar at $\$ 7.35$ per hundred. The Board absorbed the differential between this price and the price paid to the Cuban planters. ${ }^{87}$

Having thus solved the price problem. the Board's next step was to arrange for an equitable distribution among the principal governments associated in the war. The Board was saved some trouble in this phase of its work by granting an assignment to the British Royal Commission whereby its rights to one third of the sugar purchased from the Cuban planters were assumed by the Royal Commission; from this amount the Royal Commission was to provide for Great Britain and the other Allies.

There were other features of the Food Administration's policy which attracted more attention than the details related above because their success depended in part upon the publicity given them. As these activities are fresh in the minds of many, it will be sufficient to touch upon them here briefly. These activities usually

86 United States Food Administration, News Release, No. II5I Aug. 25, I918.

87 War Industries Board, Government Control of Prices, Bull. No. 3, p. 83 . 
centered on conservation measures. In October 1917. all users of sugars; bakers; confectioners and manufacturers, except those engaged in the production of essential food products were limited to 50 per cent of their prewar requirements. In January, as modified to meet the incoming supply of Cuban sugar, this regulation was changed to 80 per cent of the prewar requirements. A subsequent ruling provided "that such manufactures starting operations after November 1, 1917 but before April 1. 1918 would be limited to 50 per cent. of their sugar requirements and those starting after April 1, 1918. should be alloted no sugar whatever. Beginning March 15. 1918, practically all manufacturers using sugar were required to obtain certificates from the Food Administration in their respective states showing the amounts they were entitled to purchase." 88

Rationing is apt to be the source of much complaint unless it is carried out with just regard to individual requirements. But individual requirements in an acute shortage of a commodity, must be measured by officials. The following classifications of sugar were used by the Food Administration during July, August \& September of 1918.

Class A. included sugar used in sirups of all kinds, candies, cereals, cocoa, flavoring extracts etc. Manufacturers of this class were limited during July, August and September (1918) to 50 per cent of the amount of sugar used the corresponding months of preceding year.

Class B. included sugar used in canning and preserving vegetables and fruits, meats and milk. Each establishment of this class was allowed its full requirements. sugar used the corresponding months of preceding year. amount used in the corresponding months of the preceding year.

Class C. included sugar used in all public eating houses, hotels, restaurants, dining cars etc. The allot-

88 Blakey, R. G., Sugar Prices and Distribution, Journal of Economics, Aug., 19I8; cf. A. N. Merrit, War time control of distribution of Foods, pp. 115-125. 
ment for these during the above named months was not to exceed 3 pounds of sugar for every 90 meals served. During these same months the preceding year, or the number of meals served during June of 1918 multiplied by 3 .

Class D. included sugar used by manufacturers of all bakery products. To these was allowed 70 per cent of the amount used during the corresponding months of the preceding year or three times 70 per cent of the amount used during June this year.

Class E. included sugar sold by retailers and others for direct consumption. Those included in this class were alloted sugar for sales to householders on the basis of 3 pounds per person, per month.

The public was relied upon to decrease their consumption of sugar from patriotic motives. "Use less sugar" was a familiar slogan. Had sugar been abundant, it is perhaps safe to say that little conservation would have been practiced. As it was conservation was a necessity for most people, who either could not afford to indulge their tastes for sweets to the full extent at 15 to 20 cents a pound, or if they could afford the price, found it difficult to obtain the article. That the comparatively low price might not be the occasion of additional indulgence on the part of the public, purchases were closely watched. The Food Administration complained in September 1918 that the war had brought about increased prosperity, which had greatly added to the purchasing power of the public, "Demand for sugar had increased, it said, in response to the increased purchasing power." At first 5 pounds were allowed to urban customers and 10 pounds to rural customers. In June 1918, these rations were curtailed to 2 and 3 pounds respectively, and retailers were forbidden to sell to any customer more than 3 pounds a month. From August 1 to November 1 the elasticity of demand was further exemplified by decreasing the ration to 2 pounds. per person, per month. After November 1, it was increased to 3 pounds. With the signing of the armistice on November 11, these regu- 
lations soon were modified and on December 1 finally discarded. ${ }^{89}$ The lifting of Governmental control took place gradually, however, in order not to cause too much disturbance in the market. Some members of the sugar Division were strongly in favor of continuing regulation for a few months after the signing of the armistice and addressed a communication to that effect to the President. The President gave no response to this letter, and after the middle of December the Sugar Division was dissolved.

The effects of any Governmental control over foodstuffs can be judged mainly from two factors: first, the effect on production; secondly, the effect on price. It has been asserted that the Food Administration was in some degree responsible for the sugar shortage of 1917 and 1918. As far as production was concerned, the opposite seems to be the case. The Cuban crop of 1917-18 was a record crop amounting to 3,446,083 long tons; this high level was eclipsed by the 1918-19 crops which reached almost 4,000,000 long tons. Both of these crops were produced under prices fixed by the Food Administration. The beet sugar crop of the United States in 1917-18 was 765,207 short tons, about 49,000 tons above the prewar average. The crop for 1918-19 amounted to 765.063 short tons. The Louisiana crop was 243,000 short tons in 1917-18, and 263,450 short tons in 1918-19. To what extent, the Food Administration was responsible for these increases it is not possible to say, but in view of the above figures it can not be held that the Food Administration policies tended to discourage productions..$^{90}$

In time of war, it is essential to keep production as close to normal as possible, this can be done only by guaranteeing the producer a reasonable profit. A price must be set, therefore, that will provide for honest costs of production plus a fair margin of profit. Early in its career, the Sugar Division became aware of this principle

89 U. S. Food Administration, News Release 322, Nov. 28, 1918. 90 Bernhardt, Joshua, Government Control of Sugar in the United States During the War, p. 7rI. 
and provided a price which in its estimation was calculated to fill the above requirements. We have seen that some fault was found on the part of the Louisiana planters who claimed that the price determined was inadequate. The Food Administration thereupon showed its fairness by rectifying the price. Some discontent was expressed by the public at the inconvenience entailed by the ration system, but this was only to be expected. The saving in sugar effected by the sugar restrictions resulted in about 75,000 tons from July to November, according to the Food Administration. This saving included the amount saved by the restrictions placed on confectionery and soft drink products. ${ }^{91}$. If one can judge the results of the sugar control by the prices of sugar otbaining immediately after the suspension of regulations, no conclusion otherwise than satisfactory can be drawn. From 1914 to 1918, the average prices showed a gradual rise; the wholesale price was kept at a level by the Food Administration until the end of 1919; then came the speculative market of 1920 with all the talk of "shortage," and "hoarding" by speculators and even by housekeepers. In the summer of 1920 there was practically no market quotation; at some sales the price went well over 20 cents a pound. Then the bottom fell out of the market; sugar was selling below 10 cents before the end of the year, and by the end of January 1921 was quoted at seven and three fourths cents. ${ }^{92}$

91 U. S. Food Administration, News Release, 1342, Dec. 7, 1918.

92 The Literary Digest, Jan. 29, 1921, p. II. 


\section{CHAPTER V.}

\section{CONTROL OF MEAT AND DAIRY PRODUCTS.}

The world wide shortage of meat during the war. was due to the constant decline of meat production in Europe. The cause of this decline was found chiefly in the difficulty of raising fodder upon which the production of cattle greatly depends. Production of wheat became so vital that it would have been almost suicidal to allow the farmers of Europe to devote their energies to the production of corn, oats, and other fodder needed for cattle. Early in the conflict, England, France and Germany had established fodder rations for cattle, and as the war continued and larger numbers of cattle had been killed off without being replaced, the rations per animal were decreased. England decreased her capital stock of food animals, and put some $2,400,000$ acres of former grass and hay lands into grain growing. ${ }^{93}$

In 1917 , this decrease in the number of meat producing animals was most notable. According to figures compiled by the Food Administration, the total net decrease in cattle for the Western Allies and other countries including enemies during the first three years of the war, was $28,080,000$; in sheep, 54,500,000; in hogs $32,425,000$. Of these total amounts, the decrease for the Allies alone was $8,420,000$ head of cattle, $17,500,000$ sheep, 7,100,000 hogs.

Early in the fall of 1917, Mr. Hoover commenting upon the meat shortage of Europe in relation to our production said that the problem was fundamentally one of tonnage, for imported fodder required shipping far in excess of the tonnoge that would be required to import equal amounts of animal products. ${ }^{94}$ The supply of

93 G. Soule, "The Meat Control."-The New Republic, Feb. 2, 1918, p. 13.

94 Ibid., p. 10. 
cattle in France, in 1917, had decreased 16.6 per cent as compared with that of 1913 ; that of sheep, 33 per cent; and that of hogs 38 per cent. The supply of cattle in England suffered a total decrease of 43.3 per cent between July 1914 and July 1917. ${ }^{95}$

The United States endeavored to cover this constant shrinkage of meat production among the Allies by increasing its exports to them. For the year ending June 30,1917 , our exports of fresh and pickled meats exceeded $270,000,000$ pounds, or an increase of almost 3000 per cent over the pre-war average. Exports of ham and bacon increased $640,000,000$ pounds as compared with the pre-war average of $303,489,000$ pounds.

But not only did meat production decrease in these countries, but also in the United States. In 1907 there were $51,000,000$ beef cattle (excepting milck cows) in this country; this was the high point. By 1915 the number had decreased to $37,000,000$. Hogs on the other hand, have shown an almost steady increase from $42,000,000$ in 1896 to $64,000,000$ in 1915 . The situation with respect to mutton is highly complicated by the importance of the wool market and the tariff. In 1910 we had $57,000,000$ sheep, by 1915 only $49,000,000$.

The war effected some increase in the meat production, but nothing in comparison to the great demand. The number of cattle increased from $37,000,000$ in 1915 to $40,850,000$ in $1917 .{ }^{96}$ These decreases are very significant and serious, when the increase in population for the same period, and also the heavy demands due to war are taken into account.

As the war wore on and the break-down of the Allied meat production became more serious, the Food Administration turned it's attention to the problem of stimulating the supply. The meat problem, then, was separated into its two main factors; cattle production and hog production, each of which required special handling.

95 War Industries Board, Bulletin No. 3, p. 88.

96 U. S. Food Administration, Bull. No. 9, p. 7; cf. also War Industries Board, Bull. No. 26, pp. I-6. 


\section{CATTLE.}

For the past fifteen years, the number of cattle in the United States has decreased. From being a heavy exporter of meats we became, especially after the removal of the duty in 1913, an importer of fresh meats. Europe was importing her beef principally from South America, for cattle could be raised there more cheaply than in the United States.

During the war, the allied nations had to depend upon the United States for a large part of their beef. Vessels could not be procured to make the long haul to Argentine for beef, thus, European demand for our beef increased tremendously.

In view of the large overseas demand for our meat products, it was evident that some effort must be taken to stimulate production. But it was scarcely possible to do this while the farmer was confronted with mounting prices for feed-stuffs on the one hand, and inadequate prices for cattle on the other. The production of cattle, unlike that of hogs, depends upon a variety of grains and feed-stuffs. The problem became, then, one of stabilizing the price of these products, for uncertain prices in these materials were discouraging the cattle raisers.

Of mounting costs in feed-stuffs no better example can be given than that of cotton seed cake. From its normal figure of $\$ 45$ a ton, preceding the war the price had risen to $\$ 60$ a ton by August, 1917. At this price many cattle raisers found it more profitable to allow their cattle to starve on their ranges. The cotton crops for the two years preceding had been relatively small. Naturally enough this tended to drive prices of cotton products upward. To prevent undue speculation a meeting was arranged between the cattle raisers and the cottonseed interests, and after bitter debate, the Food Administration was able to fix the price of cottonseed cake at $\$ 50$ per ton. As most of the crop had already been contracted for by cattle raisers in the North, little relief was experienced from the fixed price by the steer raisers in Texas. The 
Food Administration, therefore, found it necessary to resort to an embargo of cottonseed from Texas, and directed dairymen in other parts of the country to seek their supplies from Arkansas, Louisiana and other points east of the Mississippi River. ${ }^{97}$

On November 1, 1917, all ginners, crushers, refiners and dealers in cottonseed were placed under license. On December 7, dealers in cottonseed in car lots were limited to a fixed margin of $\$ 2$ per ton and crushers' margins were limited to $\$ 13$ per ton over the cost of cottonseed for products obtained from crushing. ${ }^{98}$

The profits of the wheat feed-stuff producers were fixed in December 1917, when a series of differentials were announced by the Food Administration, based on the Government wheat price. A maximum return of 6 per cent on total gross sales was also announced for the manufacturer of mixed feeds. On individual sales, however, cost of materials, manufacturing, and overhead might be taken. Other coarse grains such as rice feed, and beet pulp were controlled in like manner; definite price regulations being applied to their sales. These measures had some effect upon the prices of feed-stuffs, and thereby lessened the insecurity confronting the raisers of cattle.

In addition to these regulations, conservation measures were issued by the Food Administration from time to time. A meatless day was inaugurated on November 1, 1918. Every public eating place, as well as all families were asked to pledge themselves to eat no meat on one day each week. The appeal, according to the Food Administration, resulted in a conservation of over 140,000,. 000 pounds of beef in four months. ${ }^{99}$

97 D. Lawrence: "As Mr. Hoover Sees It." The Country Gentleman, Dec. 29, I9I7, p. 27.

98 Government Control Over Prices, War Industries Board. Bull. No. 3, p. III.

99 News Release of Food Administration, Feb. 22, 1918. 
CONTROL OF THE MEAT PACKING INDUSTRY.

There was no effort on the part of the Food Administration to fix the prices of meat and meat products either directly or indirectly. In August 1917, Mr. Hoover announced to the packers that any regulations made would concern themselves with the stimulation of production, and the elimination of speculative profits. ${ }^{100}$

The meat packing industry, for many years the object of suspicion and investigation was subject to another investigation at the request of President Wilson on February 7, 1917. This investigation, undertaken by the Federal Trade Commission was not completed till July 3, 1918. It was asserted by the Commission then, "that the packers profits in 1917 were more than four times as great as in the average year before the European War, although their sales in dollars and cents at even the inflated prices of last year had barely doubled." ${ }^{101}$ The Commission estimated that the five packers, Armour and Co., Swift and Co., Cudahy and Co., Morris and Co., and Wilson and Co. handle about "half the poultry, eggs and cheese in the main channels of interstate commerce." ${ }_{102}$ One company in 1917 handled 50,000,000 pounds of butter, half of which it manufactured; the sales of another amounted to $\$ 23,861,000$. Four big companies own 56 creameries and control the output of many others. Of a total production of $152,500,000$ pounds of oleomargarine in the United States in 1916, four of these packers produced 42.5 per cent. ${ }^{103}$ In 1916, the Big Five's percentage of slaughter, including subsidiary and affiliated companies, was as follows:

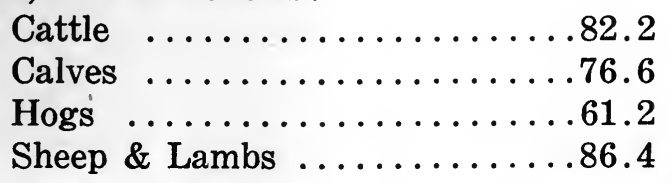

Ioo Official Statement of the U. S. Food Administration, Sept. 12 , 1918 , p. 12.

IOI Official Statement of the U. S. Food Administration, Sept. 12, 1918, p. 12 .

102 Report on the Meat Packing Industry, Part I, p. 231.

EoI Ibid., p. 223. 
These facts were by no means a revelation; other investigations had disclosed similiar charges against the packers. It is not surprising, then, in view of what was assumed unfair practice, to find that on September 12 the government proposed a plan to license the meat packing industry. The outstanding feature of these regulations was the limitation of profits for the larger packers and the prescribing a maximum return on gross sales for the smaller. On December 8, 1917, the regulations of the Food Administration fixed the maximum profit at 9 per cent on investment (including borrowed capital) for packers doing an annual business exceeding $\$ 100,000$ and $2 \frac{1}{2}$ per cent on gross value of sales for smaller packers. ${ }^{104}$

So many and diverse are the activities of the modern meat packing plant that it was necessary to define what activities were included under the packers license contral. The entire packing industry was divided into three classes, and different regulations were applied to each. Class I included all activities directly connected with the slaughtering of live stock. In this class was also included the immediate by-products. The profits from this source were limited to 9 per cent of the investment included (borrowed capital) per year. Class II included branches of the packing industry not directly concerned with products derived from slaughtered live stock. The specialty products such as canned fruits, canned vegetables, fish, eggs, butter, milk, cheese and groceries were

placed in this class for which a maximum return on the actual investment could not exceed 15 per cent. Class III included the activities of the packers, such as the fattening and feeding of live stock, slaughtering and packing in foreign countries, and the operation of banks and loan institutions. These branches of the industry were exempt from any profit limitations. ${ }^{105}$

The business investment of Classes I and II, included only investment owned by licensees and actually and

I04 Regulations of Packers' Profits, United States Food Administration, Nov. I9I7, p. 3.

I05 Government Control Over Prices, War Industries Board, Bull. No. 3, p. 97. 
necessarily used in said business. It included also the following terms: actual investment in land, buildings, machinery and equipment, the value of stocks of animals, the amount of cash on hand and other items. Unless otherwise authorized or directed by the chief of the Meat Division the licensees must estimate the value of the above-designated items according to the same methods and principles as were used by him during the year preceding November $1,1917 .^{106}$

These regulations were quickly protested by the five large packers, who contended that the maximum profit of 9 per cent allowed from Class I investments might affect their borrowing capacity. ${ }^{107} \mathrm{Mr}$. Hoover in reply stated that there would be no lack of confidence on the part of the banking community in the packers earning capacity, especially since the export demand for meats was greater than the country's supply.

Special provisions were made to enable the Food Administration to supervise closely the business of the packers in order that profit might not be concealed or diverted from the meat industry to other lines. Unreasonably large salaries or other compensations were prohibited. Licensees were required to close their books at least once in 10 weeks, and report any information relative to profits, sales and investments to the Meat Division upon its request. Furthermore, any business or industry in which a licensee held half or more than half of the capital stock must present its books and records for inspection by the Food Administration whenever requested.

These regulations for the meat packing industry were not as successful as the Food Administration expected. Many of the measures adopted by the Meat Division of the Food Administration were "developing discontent and criticism in sections of the producing community." 108 At the request of Mr. Hoover, a committee was then ap-

106 Cf. U. S. Food Administration, Rules and Regulations, Meat Division, I917.

I07 Commercial and Financial Chronicle, Dec. 15, 1917, p. 2325.

108 Letter of Mr. Hoover to President Wilson, Mar. 26, 1918. 
pointed to investigate the meat packing industry and determine a better policy of control.

The committee confirmed the value of all the existing regulations and in addition advised the licensing of the stockyards. In accordance with this suggestion, the President issued a proclamation on June 18, 1818, which required all operators of stockyards, all buyers, traders, and others who operated in connection with the stockyards to secure licenses on or before July 25, 1918.

After the signing of the armistice, it was quite natural that a reduction of foreign demand for meats should take place. We continued to ship beef to Europe for several months but as vessels became available for the trip to South America and Australia, our beef exports practically ceased. The effect of this situation was felt in April, 1919, when cattle and beef prices began a considerable decline.

\section{PRODUCTION OF HOGS.}

The question of hog production was much more vital than that of cattle production; more vital, because it involved one of the most urgent needs of this country and of the Allies. The world was consuming its fats at a greater rate than it was producing them. The quickest means of producing fat in large quantities is by the raising of hogs. Thus, the demand for fats drew the close attention of the Food Administration to the production of hogs.

Mr. Hoover was much concerned to find that whereas before 1916, 86 per cent of our hogs had been slaughtered each year, 96 per cent were slaughtered in the fiscal year of 1916-17, and the average weight had fallen from 219 pounds to 211 pounds. ${ }^{109}$

During the summer of 1917, it was found that many of the farmers in the United States were turning their efforts to the production of more profitable products than corn and hogs. They complained that market conditions were unstable and that hog raising incurred too much 
risk and not enough profit. In order to learn the facts of the case a commission was appointed by the Food Administrator. After investigating the various phases of the pork industry, and especially the cost of hog raising to the farmer, the commission reported that the price of corn upon which hog production chiefly depended had risen more rapidly than the price of hogs. Under this condition, it would be foolish for the farmer to feed corn to his hogs, inasmuch as his labor to raise them would result in a net loss. The commission recommended that a minimum price be fixed for hogs and that this minimum should be based on the prevailing price of corn. It was pointed out that the average ration of corn to hog production was about 12 bushels to 100 pounds and that in order to restore hog production to a more stable basis, a ratio of at least 13 to 1 must be maintained. ${ }^{110}$

On October 29, 1917, two days after the report of the Commission had been handed in, the Meat Division of the Food Administration was established at Chicago under the direction of Mr. J. P. Cotton. Acting on the data of the Commission, Mr. Cotton fixed the minimum price for hogs at $\$ 15.50$ per hundred weight until further notice. ${ }^{111}$ The Meat Division, according to its own assertion, had no legal means of enforcing this price. It's influence as a purchaser for the Army and Navy, Red Cross and other associations must be relied upon to effect the actuality of any fixed price. Mr. Cotton assured the farmer, however, that he could "count on getting for each 100 pounds of hog ready for the market, 13 times the average cost per bushel of the corn fed into the hogs" but at the same time wished it to be understood that, "it is not a guarantee backed by money. It is not a promise by the packers. It is a statement of the intention of the Food Administration, which means to do justice to the farmer." 112

The packers were opposed to the 12 to 1 basis, and in a letter written to the Food Administration contended that

I Io War Industries Board, Bull. No. 3, p. 89.

I I Official Statement of Food Administration, Oct. I, I9r8, p. 4.

I12 Ibid ut supra. 
this basis might prove an unduly high price on hogs at the starting of the packing season, and would result in the lower prices probably being arrived at in the spring of the year, whereas the ordinary course of the market is the reverse. ${ }^{113}$ The effect of the packers objection to the 13 to 1 basis, and the $\$ 15.50$ price per hundredweight minimum may be judged from the prices that actually obtained throughout 1918 .

Actual Average Monthly Prices of Hogs at Chicago. (per 100 pounds)

1918

January

February

$\$ 15.97$

March

16.55

April

16.87

May

16.85

June

16.77

16.42

Since the ratio method was used by the Food Administration in determining the minimum price for hogs, it will be well to explain what this method was.

The Ratio Method of Determining Cost of Producing Hogs. ${ }^{11,4}$

The method of determining the cost of producing hogs used by the committee of seven expert swine men, delegated by the Food Administration to investigate the hog industry is noteworthy because it shows a marked difference of procedure in arriving at cost.

The method is a simple ratio between corn and hogs. It is based on the assumption that hogs are condensed corn. Without any statistical devises, swine growers came to the conclusion that the value of one hundredweight of hog was equal to more than the value of 10 bushels of corn. In other words, they established the

I13 Official Statement of the U. S. Food Administration, Nov. I, 1918, p. 7.

II4 This method of cost production was advocated by $H$. A. Wallace in "Wallace's Farmer" during the summer of I9I7, and adopted practically without change by the Commission appointed by the Food Administration to determine the cost of production of hogs. Cf. "Agricultural Proces."-H. A. Wallace, pp. 30-35. 
market price of ten bushels of corn as the cost of producing each 100 pounds of hog. If they received 11 bushels of corn per 100 pounds of hog, the extra bushel might be considered as profit.

A doubt might be raised as to the accuracy of this ratio used by the farmers. Figures, however, prove with reasonable exactitude the truth of the ratio.

Taking the ten year period extending from 1907-1916 inclusive we find that, during that time No. 2 Chicago corn averaged 66.3 cents a bushel, whereas hogs averaged $\$ 7.35$ per hundredweight. The ratio for this period was thus 11.4 bushels of Chicago No. 2 corn to 100 pounds of Chicago hog flesh.

The uniformity of this ratio can be judged from the following table which gives the ten year average for the past 60 years, and the yearly average from 1908-1918.

Average number of Bushels of Corn equal in price to 100 pounds of live hog in ten year periods from 1858 to 1917, and in year periods from 1908 to 1917.

\begin{tabular}{|c|c|c|}
\hline Period & Ratio Pe & Ratio \\
\hline $1858-1867$ & 10.61910 & .15 .2 \\
\hline $1868-1877$ & .11 .71911 & .11 .2 \\
\hline 1878-1887 & 11.01912 & .10 .9 \\
\hline 1888-1897 & .11 .81913 & .13 .2 \\
\hline 1907 & .12 .21914 & .11 .7 \\
\hline $1908-1917$ & 11.31915 & 9.6 \\
\hline 1908 & 8.41916 & .11 .5 \\
\hline 20 & 310 & 9.7 \\
\hline
\end{tabular}

It will be noticed that from the $1908-17$ portion of the table, that slight fluctuations occur from year to year but that in the main, the average holds good. The same fluctuations are found also in the separate months of the year. These are seasonal periods of over-supply and scarcity of both corn and hogs. In November for instance the 1907-1916 price of corn was 67.2 cents and the price of hogs $\$ 7.23$, or a ratio of 10.6 bushels to 100 pounds of hog flesh, while in March of the same ten-year period the average price of corn was 61.7 cents and the price of hogs $\$ 7.66$, or an ratio of 12.4 bushels of corn for one hun- 
dred pounds of hog flesh. By accurate information and calculation it has been found that there is a normal ratio for each month in the year.

A difficulty here arises that seems to affect the general conclusion. As the prices of corn fluctuate from month to month and from day to day and as it requires a number of months to raise hogs for the market we must weight the numbers as accurately as possible to represent actual conditions. "The Committee assumed that the corn going into the making of a hog was distributed over twelve months; that during the first month over 2 per cent of this corn went into the hog or its dam; the second month, 2 per cent; third month, 2 per cent; fourth month, 3 per cent; fifth month, 4 per cent; sixth month, 6 per cent; seventh month, 5 per cent; eighth month 9 per cent; ninth month, 15 per cent; tenth month, 20 per cent; eleventh month, 17 per cent, and twelfth month, 15 per cent. We find that during the ten year period, 19071916, the average corn ratio for January was 11 bushels; February, 11.6 bushels; March 12.4 bushels; April, 12.7 bushels; May, 12.3 bushels; June, 12.1 bushels; July 12 bushels; August, 11.8 bushels; September 11.8 bushels; October, 11.3 bushels ; November 10.6 bushels and December, 10.4 bushels." ${ }_{115}$

Suppose, for example, we wish to find the cost of producing hogs for the Chicago market for the month of April, 1918. We begin with the corn values of April 1917 and each month consecutively till April 1918. The actual prices of No. 2 corn at Chicago for these twelve months were as follows: 144.9 cents, 163.9 cents, 170.9 cents, 200 cents, 197.2 cents, 208.6 cents, 199.2 cents, 201 cents, 173.2 cents, 180.6 cents, 174.5 cents, and 172.3 cents. Weighting these prices on the basis indicated, we get a composite value of corn of 182.5 cents.

The historical ratio for the month of April is $\mathbf{1 2 . 7}$ bushels of such composite corn. Multiply 182.5 cents by 12.7 and we secure $\$ 23.18$ as the cost of producing hogs

II5 H. A. Wallace.-Agricultural Prices, p. 32. 
for the Chicago market of April 1917, under the ten year ratio method.

Upon the report of the Commission the Food Administration announced that it would use every means to pay the hog-raisers the equivalent of 13 bushels of corn for each 100 pounds of hog flesh during the year 1918 . Since this ratio was an advance over the historical ratio of 11 bushels per hundredweight it was expected to have a strong influence toward enlivening hog production.

Despite its guarantee, however the Food Administration found it difficult to maintain its agreement.* An effort was made, early in September 1918, to show that the 13 bushels ratio agreement was based on prices of corn at the farm and not at Chicago. This was asserted in spite of the fact that the printed announcement of the Food Administration in 1917 specifically stated Chicago prices. The difference in price to the farmers from this maneuver was a loss of about $\$ 2.50$ per hundredweight. The Food Administration explained its position on the ground that previously agreed prices were too high for export trade. The price then fixed by the Food Administration was a minimum of $\$ 15.50$, which was really a ratio of 10.8 bushels. A wide-spread indignation among the hog raisers resulted from such a repudiation of its promises on the part of the Food Administration: "The committee of some fifteen men," writes Mr. Wallace, "supposedly representing the American hog producers, which met with the United States Food Administration in this matter, were not well educated along statistical or economic lines, and they went down to defeat in Septem-

* Considerable light is thrown upon the position of the Food Administration in its effort to maintain the minimum price, by comparing corn and hog prices during this period Owing to the guaranteed price for wheat, corn acreage decreased over 12 million acres between 1917 and 1918 , and showed a further decline of over 4 million acres between 1918 and 1919. The effect of this was an abnormal increase in corn prices. Corn prices rose from a pre-war (July I, 1913, to June 30 , 1914) average of 67 cents per bushel to \$1.59 per bushel in January 1918, an increase of 133 per cent. Hog prices rose from $\$ 8.30$ per hundredweight in the pre war year to $\$ 15.97$ per hundredweight in January, 1918, an increase of 91 per cent. 
ber, 1918, scarcely knowing what the Food Administration had done to them." 11,6

The "13 to 1" ratio price basis $\$ 15.50$ set by the Meat Division did not long continue to operate. In January 1913 , the prices had fallen to $\$ 15.17$. In February, however, prices rose to an average of $\$ 16.55$ around which they fluctuated till June. In August 1918, a pronounced decrease in the supply took place sending prices to $\$ 18.75$. The peak was reached in September when the price advanced to $\$ 19.75$. The Food Administration again assumed control and by withholding European Orders, kept prices from mounting higher. The packers agreed to maintain as far as possible a $\$ 15.55$ minimum for average droves as well as to maintain the price on the ratio of 13 to 1 .

On December 10, 1918, the Food Administration put into effect the zone system of marketing live stock at Chicago. According to this system hogs would be received from points within 300 miles of Chicago on Tuesdays and Thursdays. Hogs shipped outside of the 300 mile limit would be bought on Mondays and Wednesdays. On Friday and Saturdays hogs were to be received from any section. The object of this regulation was to provide a more uniform number of hogs each day for the market, which would thereby tend to stabilize prices.

"This 300 mile zone method lasted just one month," observes Wallace's Farmer "and during that month the variation in receipts and prices was greater than in the same period (from December 10 to January 10) during any previous year." "1,17

In January, 1918, the average price of hogs at Chicago fell to $\$ 15.97$. The Food Administration, in order to prevent the price from falling below the minimum secured as many orders for pork products as possible from

I16 Wallace, H. A.-Agricultural Prices, 1920, p. 35.

II7 Wallace's Farmer, January 18, 1918, p. 76. During the same period in 1914-15 the variation in average price on different days of the week was 6 cents, in 1915-16, and in 1916-17 7 cents. During the month of experimenting with the zone system, the variation was 32 cents. 
the Army and Navy and also from the Allies. In February, the salutary effect of these solicited purchases was reflected in the price of hogs, which rose to $\$ 16.55$.

As early as October 1918, reports of peace circulated. Farmers began to send their stock to the market in vast numbers. This sudden supply brought a decline of from 25 to 40 cents per bushel in the price of corn, ${ }^{11.8}$ and also a drop from $\$ 19.37$ per hundredweight to $\$ 16.75$ for hogs. The arrival of hogs at the market during the first three weeks of October was 27 per cent larger than in the corresponding month of the previous year. The fear also that large quantities of cheap corn would be shipped from Argentine and South Africa increased the probability of downward prices.

The post-war demands of the Allies, however, stimulated the price during the latter part of October to an average of $\$ 16.62$. An agreement was made with the packers supplying government orders whereby not less than a daily minimum price of $\$ 17.50$ per 100 pounds was to be paid for the average packers droves. A Committee was appointed to supervise the market and regulate the flow of hogs to the market in accordance with the capacity of the various packing centers.

It was expected that European nations would renew their demands for pork products long after the close of the war. During the first two months of 1919, foreign demand was brisk, but in March it notably declined. Prices, however, remained high, because hog receipts fell off. During the summer and fall of 1919, owing to the decline of European demand a most spectacular drop occured.

\section{POULTRY AND EGGS.}

The poultry industry was not subject to as complete a control as other products, yet the regulations enforced were considered irksome by many producers. Early efforts were made by the Food Administration to license

II8 U. S. Food Administration. News release, No. I269. 
all packers and shippers, commission merchants, wholesalers, jobbers and suppliers of hotels and institutions. The Department of Agriculture, aided the Food Administration in suggesting ways and means of expanding the poultry industry. City and suburban residents, who had available plots of ground were urged to raise chickens, in order to utilize all table waste, and increase the annual egg output.

Poultry raisers were interested in the cost of corn, and the price of eggs. Mr. Priebe who acted as head of the Poultry and Egg Division of the Food Administration early in November, 1917, when the price of corn was high, promised that something would be done to reduce the price of corn.

Apparently his words were taken too literally, as poultry magazines and journals were constantly reminding him throughout 1918, of his promise. ${ }^{119}$ The average wholesale price of corn in Chicago in August 1917 was $\$ 1.92$ per bushel, in September $\$ 2.07$, in October $\$ 1.96$, in November $\$ 2.05$. Throughout the year 1918, the price ranged from $\$ 1.77$ to $\$ 1.38$ per bushel, as compared with 49 cents to 74 cents per bushel in $1913 .{ }^{120}$ If prices were to be fixed at all, the poultry producers hoped that the first price fixed would be that of corn.

On the other hand, eggs, firsts, and freshly gathered do not show a range in price relative to that of corn. The average wholesale price in New York in August 1917 was 38 cents per dozen; in September 40 cents; in October 40 cents; in November 48 cents; and in December 56 cents per dozen. In January the wholesale price reached 65 cents, and retail prices advanced to $\$ 1.00$ and $\$ 1.10$. In March the market broke, and the price fell to 38 cents. In April and May the average price was 34 cents a dozen. ${ }^{121 .}$

The average wholesale price of dressed fowls for the

II9 American Poultry Journal, Feb. 1918, p. I59.

I20 Bulletin of Monthly Prices. Price Section of War Indus. tries Board, p. 42.

I2I Ibid. p. 43. The increase in the average retail price of egg 3 for the period I9I3-20 may be consulted from the table on p. 23 . 
month of August 1917 at New York was 24 cents per pound; for September 27 cents, for October 28 cents; for November 23 cents, and for December 26 cents. Prices ranged in 1918 from 29 cents to 35 cents per pound.

The regulations of the Food Administration were designed to prevent waste and speculation primarily, and to control prices only by limiting margins of profit. Those handling poultry were to keep their goods moving to the consumer in as direct a line as practicable, and without unreasonable delay. Re-sales within the same trade, especially if tending to result in a higher price to the retailer or consumer were prohibited. The original packer or shipper, storing in a cold-storage ware-house was prohibited from selling frozen poultry to wholesalers at an advance of more than 6 per cent over cost. Commission merchants and wholesalers were restricted to margins not in excess of 5 per cent over cost. The maximum margin allowed to original packers or shippers of storage eggs was 6 per cent over cost; while commission merchants and wholesalers were limited to 4 per cent over cost or 7 per cent if the eggs were candled.

Poultry producers complained of the low market prices for eggs in the spring of 1918. Some asserted that Mr. Priebe, head of the Poultry and Egg Division partly brought about this drop in prices by his statement to the effect that the country was facing an egg famine. "We have got to cut down the egg consumption or else suffer a fast approaching famine. The people in the cities should do like the country folk, not buy eggs when the price is out of reach." ${ }_{1,22}$ It was also stated that 80 per cent of the cold storage supply of eggs had been consumed between September 1 and January 1.* It was widely intimated too, that the head of the Poultry and Egg Division who was also president of a large packing concern was acting in his own interest in attempting to reduce the demand for eggs in order to glut the market early in the spring. By asking consumers not to buy

122 American Poultry Journal, Feb. 1918, p. 160.

* Cold storage dealers, however, did not credit this statement, and the government figures showed an increased holding of eggs of more than 20 per cent over the preceding year. 
eggs, greater supply of storage eggs would be on hand, tending to reduce the price to packers for spring shipments.

In a statement made to the Reliable Poultry Review, Mr. Priebe explained that the low price of eggs in March and April of 1918 was due to the unusually severe weather of January and February which held back the eggs and the moderate weather of March and April which sent them in large quantities to the market. ${ }^{123}$

Much criticism was expressed against the so called Rule 15 of the Poultry \& Egg Division. This rule prohibited licensees from trading in live or freshly killed hens and pullets. Put into effect in the latter part of February 1918, at a time when poultry raisers are accostomed to kill off fattened and unproductive hens for the market, it resulted in losses. Such birds would have to be fed at a loss for they "would not begin laying again for at least 60 days or more." Designed to increase the production of eggs, this regulation was felt an injustice by producers, who lost the best live poultry trade of the season. It was also claimed that packers would reap abnormal profit from the selling of storage poultry. The effect of this order was "the greatest rush to sell off both large and small farm flocks that we have ever knownthousands of fowls and pullets were thrown on the market (before the regulation went into effect) and the local (Chicago) market price of live poultry dropped from 32 to 26 cents a pound." 124

On the other hand, the Food Administration estimated that at least $3,000,000$ hens were saved in New York, Chicago and Boston alone. ${ }^{125}$ The weather conditions of March and April brought about an early laying and hatching period, and by the middle of April Rule 15 was lifted.

I23 Reliable Poultry Review, May I8, p. 375.

I24 American Poultry Journal, March I9I8, pp. 56I \& 4 IO.

I25 Government Control Over Prices, p. IoI. 


\section{CONTROL OF MILK.}

The Food Administration exercised little control over the prices and distribution of milk. In view of the fact that the problem is largely a local one, and complicated usually by State laws, the administration adopted the policy of non-interference wherever possible. Neither producers nor dealers were licensed by the administration. It was only when disagreements between the milk producers associations and the dealers reached a deadlock that the Food Administration was invited to act as mediator.

As a complete study of the milk situation during the war would involve an analysis of the activities of many district commissions chosen to investigate local conditions, and would reveal practically the same methods of handling, it will suffice to outline the work of two of these commissions-those of Chicago and of New York City. These cities are sufficiently representative as far as the milk situation was concerned, to furnish an adequate summary of the entire problem.

During the past fifteen years, city distribution of milk has been largely taken over by companies. The rapid growth of these companies soon gave them a dominating position in bargaining with milk producers. The number of distributors in Chicago decreased from 2,700 in 1893 to 688 in 1917, of which number, two companies were distributing approximately 40 per cent of the total. This concentration of control brought about many economies in distribution, better service and more sanitary precautions. But at the same time, the farmer found himself at the mercy of these powerful bargaining concerns who practically dictated the price they would pay for his product. Should the farmer be unwilling to dispose of his milk at a price which he thought was unfair, he was forced to find a customer for his product.

To combat this control of distributors, there arose the Milk Producers Association of Chicago. This union first made its strength felt in April 1916, when it de- 
manded an increase in the price for whole milk. Refusal on the part of the distributors to accede to its demands brought threats of "dumping" the milk. The rise was finally paid by the consumer, milk going from eight to nine cents a quart at retail. In April 1917, a similar struggle took place which resulted in ten cents a quart milk for the consumer.

The price of milk depends largely upon the price of feed-stuffs. We shall note changes in the prices of both. Corn sold for 57 cents per bushel, at Chicago on May 1, 1913. In 1915 , on th esame day, the average price was 76 cents; whereas the supply had increased about 13 million bushels the demand had apparently increased to a much greater extent.. In 1917, the average corn price was $\$ 1.67$ and the following year reached about $\$ 1.45$ per bushel. ${ }^{126}$ Our production of oats amounted to $35,470,000$ bushels in 1917, yet the price advance was almost 60 per cent higher than the preceding year, when the supply was only $20,265,000$ bushels. The high level of 1917 was reduced almost 60 per cent in 1918; the increase in price was 10 per cent. No. 2 Alfalfa at Kansas City rose from an average prewar level of $\$ 12.19$ a ton to an average price of $\$ 20.04$ in 1917 and $\$ 21.29$ in 1918. During November and December of these years alfalfa sold for $\$ 27.25$ and $\$ 27.75$; $\$ 26.75$ and $\$ 23.25$ respectively. In July 1917 , it was estimated that feedstuffs were selling at a level 118 higher than during the prewar year. ${ }^{127}$ These advances correspond to the advances in the general level of prices during this period, but eclipse those for food by about 20 per cent. It was only to be expected, then, that the price of milk should be correspondingly high.

Both wholesale and retail milk prices appear to have been surprisingly stable till the autumn of 1916 . The following table shows the relative price fluctuations in the wholesale and retail milk market for New York and Chicago. ${ }^{128}$

I26 War Industries Board. Prices of Feed \& Forage, 1920, p. 7.

127 Ibid. p. I3.

I28 Monthly Labor Review, Dec. I920, p. 67. 
Index Numbers of the Average Wholesale and Retail price of Milk at New York and Chicago.

(Average for 1913-100)

$\begin{array}{llcrrr}\text { Milk, New York } & 1913 & 1914 & 1915 & 1916 & 1917 \\ \text { Fresh--Wholesale } & 100 & 86 & 86 & 86 & 143 \\ \text { Fresh--Retail* } & 100 & 100 & 100 & 100 & 127 \\ \text { Milk, Chicago } & & & & & \\ \text { Fresh--Wholesale } & 100 & 95 & 97 & 95 & 124 \\ \text { Fresh--Retail* } & 100 & 100 & 100 & 101 & 125\end{array}$

From the above table, it may be seen that the average retail price of milk did not rise in New York during the years 1915 or 1916, and that the rise in Chicago was one per cent during the year 1916. In the following year an advance of 27 per cent took place in New York, while that for Chicago was 24 per cent. As compared with the 118 per cent rise in feedstuffs, these advances in the price of milk appear insignificant. In 1917, both wholesale and retail prices of milk rose gradually. Each increase asked by the dairymen was reluctantly granted by the distributors. Finally in October, the latter refused to grant the increase asked by the dairymen. The Food Administration was then requested by both dairymen and distributors to determine what price should be paid to the farmers for milk.

The first step taken by the Food Administration was the appointment of a committee to investigate costs of milk production and distribution. The committee suggested that contracts between producers and distributors be made on a monthly basis, instead of a period of six months, as had been customary. By means of monthly contracts, the price of milk could be kept at a ratio with the prices of feedstuffs. This suggestion, though adopted, does not appear to have relieved the situation, for further appeals were soon addressed to the Food Administration.

When the producers and distributors met to sign the contracts for October 1917, the Milk Producers' Associa-

* Bottled \& Delivered. 
tion of Chicago demanded $\$ 3.43$ for each 100 pounds of milk. This demand was one cent higher than the price offered by the distributors. After some delay, the latter finally acceded. The retail price advanced from 10 to 13 cents a quart: consumption showed a decrease of about 20 per cent.

Definite action was taken in November, 1917, when regional commissions were set up by the Food Administration in Boston, New York and San Francisco. These Commissions were composed of representative producers, distributors and consumers in the several cities. ${ }^{129}$ It was their duty to collect data and make investigations upon the cost of producing and distributing milk. The producers and distributors of each district voluntarily agreed to abide by the decisions of the committee, but were given the right to withdraw from any agreement upon 30 days notice.

It required practically two months to hear the testimonies of farmers, distributors and agricultural experts. Production costs varied widely and the commitee found great difficulty in determining average costs. The Committee, in their report on the costs of production, advised the adoption of the formula method with various modifications to meet conditions in different districts. ${ }^{130}$ The formula used by the Chicago Commission was known as the Modified Pearson Formula. This formula as adopted to meet the requirements of the Chicago district, comprised the following ingredients : 20 pounds of home grown grains, 24 pounds of manufactured feeds, 110 pounds of hay, and 3 hours of labor. These items were taken as correctly representing the average amount of feed and labor required to produce 100 pounds of milk.

"The value of the 20 pound of grain and the 110 pounds of hay were to be determined by using farm values of hay and corn in the states of Illinois and Wisconsin reported by the Agricultural Department on the

I29 Ibid. p. I07.

I30 C. L. King, "The Price of Milk," p. III. 
first day of the preceding month."131, The value of 24 pounds of feed was to be computed from the prices of feed in the daily Feed Report published at Milwaukee. The value of three hours of labor was to be determined by the average going prices for farm labor paid within the Chicago District.

A Committee of experts appointed to report to $\mathrm{Mr}$. Hoover based its conclusions upon the records of 490 dairy farms, producing milk for city markets in six northern states. These States were: Minnesota, Michigan, Massachusetts, Connecticut, New York and New Jersey.

As computed according to this formula, the Commission, on February 2, announced that the following prices should be paid the dairymen. February $\$ 3.07$; March, $\$ 2.83$; April, $\$ 2.49$; May, $\$ 2.04$; June, $\$ 1.80$; July, $\$ 2.30$; August, $\$ 2.75$ per hundred pounds of whole milk.

The price fixed was always for 3.8 per cent milk;* four cents was added for better fat, for each point above that mount and the same amount to be deducted for each point below 3.5 per cent.

The price to consumers was to remain at twelve cents per quart, with the provision that if the prices paid to the dairymen advanced, and the distributors found themselves unable to deliver at this price, proper increase to cover extra costs was to be added by the distributors.

These prices, agreed to by six of the nine commissioners, were proposed to the producers, but were not acceptable. Two representatives of the Food Administration were then called upon to review the findings of the commission. These representatives confirmed the conclusions drawn up, but on March 1, were prevailed upon to make the price $\$ 3.10$ per hundred pounds instead of $\$ 2.83$ as previously determined by the Commission.

The Modified Pearson Formula was in use in determining the Chicago milk prices for about six months. Im-

131 Ibid. p. I13.

* 3.8 per cent. milk contains the average amount of butter fat. 
mediately after the withdrawal of the Food Administration, the formula method was abandoned and another method adopted to secure higher prices.

The milk situation in New York was treated with practically the same methods as were used in Chicago. Prices were first fixed by the Milk Commission for January 1918 and altered from month to month according to a formula submitted by Professor Warren and approved by the Producers and the Committee.

In May, 1918 however, virtually all the milk distributors decided to withdraw from the agreements the following month. Producers and distributors finding it difficult to come to any agreement by themselves, called in the Food Administration to act as mediator in arriving at a fair price. The Food Administration, after a study of the situation suggested a price of $\$ 2.70$ per 100 pounds of milk for the month of August and $\$ 2.90$ for September. These prices were accepted and for the remainder of the year, the Food Administration continued to act as mediator. ${ }^{132}$

The price fixed fof the New York district was based upon the Warren Formula: namely, that to produce 100 pounds of milk of the average butter fat (3.8 per cent) the following feed and labor units were required:133 Grain, 33.79 pounds; Hay, 43.3 pounds; Other dry forage, 10.8 pounds; Ensilage, 92.2 pounds; Other succulent food, 8.3 pounds; Human labor 3.02 hours.

The formula method, while accurate as a method for ascertaining production costs, is not infallible. Though the formula may remain constant for many years, it is always conceivable that a change in production methods may come to enable farmers to produce milk at a lower price than the formula indicates. The formula method when used in price fixing is open to several objections. It may be necessary for months at a time to cater to consumers by selling a product below the formula, or the

I32 War Industries Board Bulletin, No. 3, Government Control Over Prices, p. I08.

I33 C. L. King, The Price of Milk, p. II9. 
cost of production price. In trying to apportion the profits of the year equally for each month, price fluctuations are bound to be frequent. Consumers, as a rule, prefer constant prices, which require no shift of demands as soon as prices rise, though the rise last but for a month, consumers will lessen their demand. The result will be lower profits, perhaps, than those founded upon the basis of "supply and demand. Such price stabilization does not mean that farmers will receive less for their annual output. During the summer months, the spread must be made wide enough to create reserves against the lean months of the autumn and winter. 


\section{CHAPTER VI.}

\section{CONTROL OF CANNED GOODS.}

The Government was interested in canned goods during the war, and watched advancing prices for these goods with much concern. Large orders needed for the Army and the Navy would result in the unnecessary expenditure of thousands of dollars, if prices were not curbed. On April 23, 1917, the Government placed an order $^{134}$ for 35,000 cases of No. 3 tomatoes, 50,000 cases of peas, 40,000 cases of corn, 290,000 cases of string beans, 10,000 cases of asparagus, 9,000 cases of pumpkin, 9,000 cases of spinach, 9,000 cases of saurkraut, 5,000 cases of beets, and 20,000 cases of Alaska red salmon. This enormous demand, at a time when the supply was low, resulted in a sudden jump in prices. The bids received on this order were considered too high by the Government Buying Committee. The President, however, ordered the lots to be taken over at prices which would be later determined as reasonable. ${ }^{1,35}$

Three weeks later, during which time Mr. Hoover had watched the prices of canned goods, the industry was alarmed by his threat to place packers and jobbers under licensed control. Prices were too high. Goods were being held for speculative profits. Unless a speedy change took place, he said, the industry would be met with regulated profits.

This announcement had immediate effect in bringing down prices. The canners appear to have held but a small percentage of their output, the custom in the trade being to sell about 90 per cent of the pack as futures in the fall. Speculators and merchandising brokers who held the largest percentage of the remaining stock now

134 The Canning Trade, June 4, I9I7, p. I0.

I35 Ibid., April 23, 1917, p. 10. 
endeavored to unload quietly before prices dropped too much. Buyers, on the other hand, anticipating price regulations, were unwilling to buy any more than they had immediate need for. Later, when this scare had passed over, it was found that very little stock was in the market. Trade journals accused Mr. Hoover, in this instance, of undue interference, which was productive of more harm than good.

Prior to our entrance into the war, price changes in canned goods had kept pace with changes in the general level of prices. Even at this time the prevailing sentiment among the canners was that prices of canned goods were too high. ${ }^{136}$ But as prices continued to rise, and threats of drastic government control were spread abroad, this sentiment rapidly changed. Those who held goods sought to reap the harvest while the opportunity lasted. The Canner, a weekly journal of Chicago, exemplifies the typical attitude of the industry at this time when it advises packers thus: "Keep your nerve and sit tight and you can get your own price for your spot tomatoes-but weaken and the jobbers who are pursuing a hold-off policy will get them at prices below what they are worth." ${ }^{137}$

The following table will show the average monthly range of prices for corn, tomatoes, peas and pumpkin during the year 1916.

Monthly Range of Prices During 1917.

Figures taken from issues of "The Canning Trade;" the issue nearest the 1st of each month being used. Prices quoted represent the lowest per dozen cans, in wholesale quantities f. o. b. Baltimore. See table on following page.

The profits of the packers and brokers were large during the year 1917, yet not excessive when compared with the general rise in the value of money. The Federal Trade Commission in its Report on Canned Goods says : "In 1916, 42 packers, representing invested capital

I36 Ibid., May 14, I9I7, p. I.

137 The Canner, March 9, 1917, p. 20. 
Control of Canned Goods.

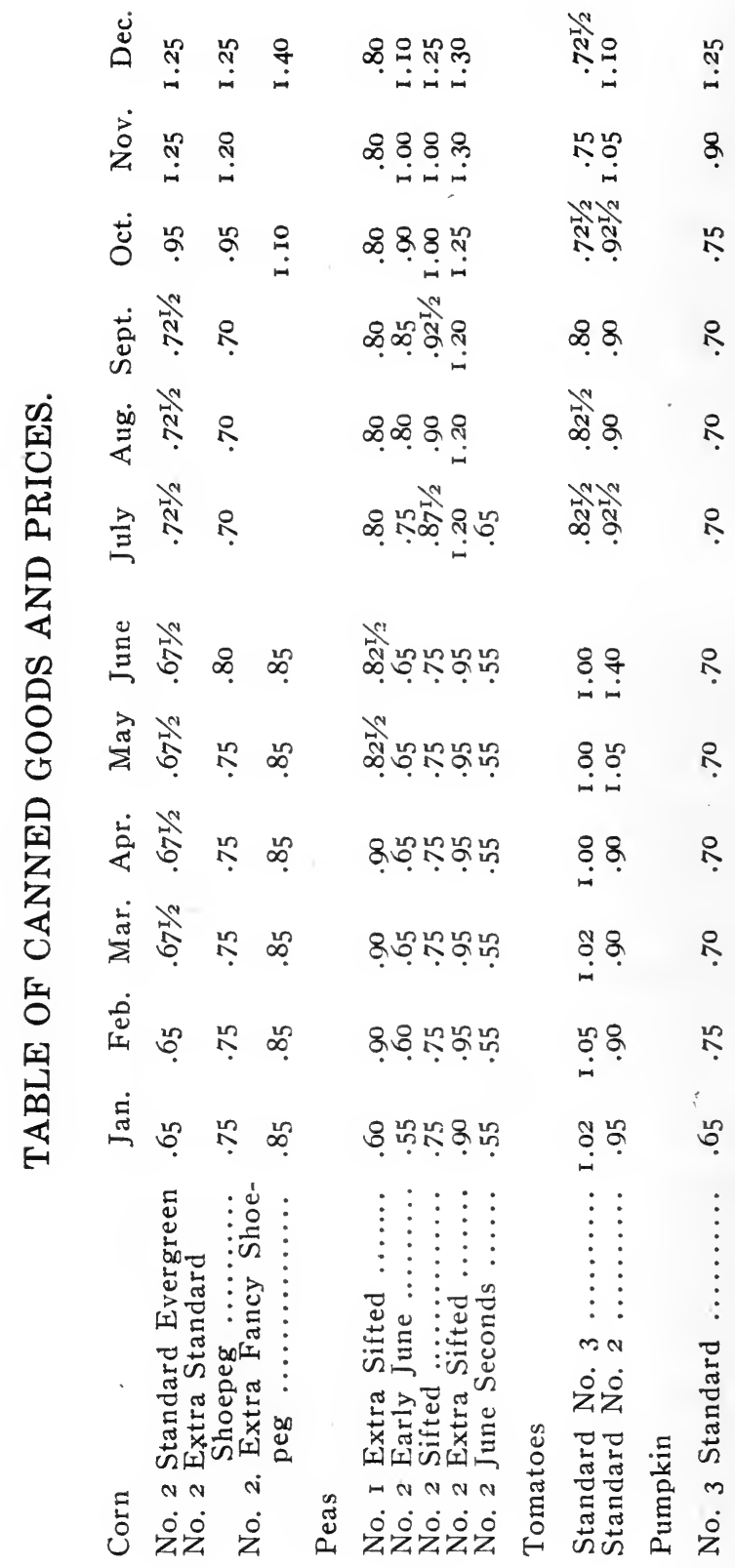


amounting to $\$ 12,752,241.03$, showed net incomes aggregating $\$ 1,244,009.69$. Thus, the return on investment of these packers averaged 10 per cent. In 1917, 37 packers, representing invested capital amounting to $\$ 12,224$,210.68 , showed net incomes aggregating $\$ 3,876,263.08$. The average return for this year was 32 per cent." ${ }_{138}$ The average profits for 1916 were small because, most of the pack had been sold at futures when prices were low. The profits of the brokers and jobbers doubtless were higher, for they had the advantage of a rising market.

In order to come to some argeement as to Government purchases, the canners were called into conference on June 13, 1917. The method adopted was to apportion each Government order among all canners, based on the capacity of each firm. No canner was to be called upon for more than 10 per cent of the pack. The canners were to suggest a price, and if this was suitable to the Government, the goods were to be purchased at that price. The following bulletin issued by the Council of National Defense shows the successive steps pursued in the purchases of canned goods by the Government.

A. In arriving at prices "fair and just" to be paid by the Government, the Quartermaster Department of the Army has asked the Bureau of Accountancy of the Department of Commerce to assist.

B. Said Bureau asked a Committee of representative canners, brought to Washington for the purpose, to submit a schedule of prices which the Committee considered reasonable and likely to be acceptable to the whole trade, with the understanding that the same would be looked into by the bureau and approved if found to be "fair and just."

C. After considering the advantages and disadvantages of different prices for different localities, it seemed best to ask every canner in every section to furnish his quota of peas at the same price f. o. b. factory. 1918.

138 The Federal Trade Commission, Report on Canned Goods 
D. The Army and Navy desire approximately 75 per cent of their requirements of peas in standards* and 25 per cent fancy.

E. The Committee mentioned in B submitted the following prices per dozen:

\section{Fancy Sweet Wrinkled}

Fancy Alaskas Standard Alaskas
Standard Sweet Wrinkled

$\begin{array}{rrr}\text { No. } 3 & \text { No. } 4 & \text { No. 5 } \\ \$ 1.50 & \$ 1.35 & \$ 1.25 \\ 1.50 & 1.30 & \\ 1.30 & 1.20 & 1.85 \\ 1.30 & 1.15 & \end{array}$

F. The prices were f. o. b. cannery. In addition to the above prices 8 cents extra was allowed for cases.

This method of making purchases at prices determined by the canners and subject only to Government approval was, however, nothing more than a temporary arrangement made necessary on account of the difficulties inherent in more stringent control over the canners prices. The Food Administration had before this issued the general regulation for all canners that prices were to be restricted to a "reasonable advance over costs." 139 According to this rule, prices might differ widely, for almost every canner had costs different from every other canner. The necessity for prices based on average costs became apparent to the Food Administration and accordingly at the request of the President on February 7, 1918, an investigation into the costs of production and distribution of canned vegetables and fruits was undertaken by the Federal Trade Commission. This study including approximately 40 corn canners, 20 tomato canners, 18 pea canners, 12 string bean canners and 10 canners of fruit or about 25 per cent of the total canned vegetable industry of the country was not completed until May 18, 1918. The report emphasized the difficulty of arriving at

* Official Measurements of Standard Cans.

Diameter. Height.

No. I size.........2 I 16 in........... in.

No. 2 size........... 7 -16 in............

No. 3 size.........4 $1-4$ in............

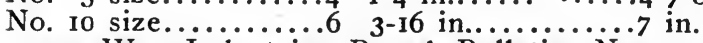

I39 War Industries Board Bulletin, No. 3, Government Control Over Prices, p. II5. 
any satisfactory conclusions regarding costs on account of the differences in kinds of goods, sizes, and grades. No method of standard grading was used, and as prices depended upon grades, the same pack for one canner might be sold for more money by another. Raw materials varied considerably in price also, due to the location in which they were grown. Corn in 1917 cost $\$ 20$ per ton in Maine and only about half that amount in the Middle Western corn belt, and tomatoes in the same year cost twice as much in Maryland as in the West.140

This report was completed in time for the Food Administration to make use of its data for the 1918 crop. The problem of fixing prices and profits for canned goods was, indeed, a complicated one. Should a fixed price be placed upon each can of corn, tomatoes, or peas etc., or would it be better to fix the price upon the average case of these goods (usually 24 cans to a case)? Such a method would necessitate a thorough knowledge of all the different grades of vegetables, fruit and fish used in canning, and must also take into account the many different weights of can contents. On the other hand, a differential might be declared for each product, grade and size of can. But considering the wide difference in the cost of production, and the ease with which figues might be manipulated, such differentials would result in a considerable difference of price for the same product. However, as jobbers, brokers and wholesalers would still purchase from packers, there would be small opportunity for the latter to advance prices by confusing grades. If an individual packer asserted that his costs were higher than those of other packers in the same market, and that therefore he might freely take the maximum differential that would be fixed by the Food Administration, he would find himself in competition with other packers of lesser costs. Practically, therefore, the packer must take care to have his costs no higher than the average costs of other packers. Only a

I40 Federal Trade Commission, Report on Canned Goods I9re, p. 2. 
shortage of canned goods would enable him to show apparent disregard for costs. But if the Administration could make vegetable and fruit growing profitable enough for the producer, and furthermore would fix a reasonable margin for canners, shortages of canned goods, as far as human effort, was concerned, would be improbable.

With these considerations the Food Administration decided to fix margins for the canners, and jobbers. By way of gaining some information upon costs, the Administration asked each canner to submit cost estimates for each of the varieties he packed. These estimates were then compared with those furnished by the Federal Trade Commission as a basis for establishing fair margins of profit.

Early in 1918, the Food Administration fixed the margins for canners for each product, at the same time issuing regulations as to the size of can, volume of content and grade. These margins were applicable not to single cans, but to dozen lots.

The following table shows the margins allowed to canners during 1918, upon canned corn, canned peas and canned tomatoes, for standard and fancy grades.

Maximum Margins on Canned Goods in 1918.

Corn (Per dozen cans Cents

No. 2. Standard ..................... 19

No. 2. Extra Standard .................22

No. 2. Fancy ......................30

Peas

No. 2. Standard (average for all sizes) ....... .22

No. 1. Sub-Standard (Average for all sizes) ... .15

No. 2. Fancy (average for all sizes) .........31

Tomatoes

No. 2. Standard ..................18

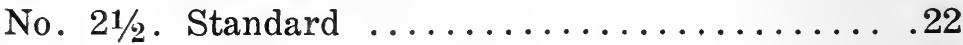

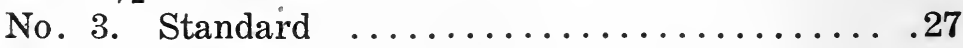

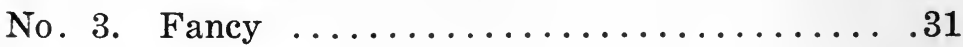

No. 3. Standard ..................90

No. 10. Fancy ........................ 00 
When these margins were announced together with those of jobbers, many jobbers had fancy grades on hand, bought as futures at lower prices than then prevailed for standard stock. A selling price for these goods based upon cost, would have placed them at a lower price than the standard goods. This difficulty was adjusted by allowing the jobbers to average their grades, and thus receive higher prices for their fancy goods than the regulation, literally interpreted, allowed..$^{141}$

All canners whose output exceeded 5,000 cases per year were licensed by the proclamation of October 8 , 1917. On January 10, 1918, this amount was lowered to 500 cases per year, thus including virtually the whole industry.

Early in November 1917, before the maximum margins on canned goods had been declared, an effort was made by the Food Administration to check speculation in the canning trade. The method first employed was that applied to many other industries, namely the prohibition of long-time contracts. It was found, however, that this ruling worked to the detriment of the small packer. Before beginning his operation, the packer in order to secure a supply of fresh products for his plant, contracts with neighboring growers for a certain number of acres of produce. Then, he buys his stock of cans, packing cases, machinery labels etc. As the industry is largely composed of men of small means, who are unable to finance these operations, loans from banks are necessary. Before the bank will loan any money it usually requires the packer to show some evidence of a market for his goods. Contracts with brokers and jobbers for future sales must, therefore, be made, before the packer begins his operations. The ruling prohibiting contracts from being made before February 1 of the year in which the pack was to be sold rendered it difficult at this time for the packer to get the necessary loans from the banks.

I4I Federal Trade Commission Report Canned Goods, I9I8, p. 64 . 
The usual ruling of the Food Administration prohibiting future contracts more than 60 days in advance were, therefore, not applied to the packers.

But a glance at any of the canning journals at a later period will make it apparent that this/exemption was altogether unnecessary. Longtime contracts, by force of circumstances became a thing of the past. Buyers complained that the canners refused to sell futures except at prices ruling at the time of delivery. "Canners of all kinds have seen the light as regards the selling of further futures and it is indeed a 'rara avis' who can be found willing to sell now." 142 One big shipper expressed his views of futures thus: "I may be an awful fool not to contract for my entire pack at the prices I can obtain today, but if I were to do so, and prices should keep going up, I am likely to be a bigger fool for having made contracts at prices that would seem very low compared with present values." ${ }_{143}$

Restrictions upon the canning industry were removed early in 1919. During the Food Administration's control prices were kept comparatively stable. This control of canners' margins resulted, according to the claims of the Food Administration, in a saving to American consumers on the 1918 pack of peas, tomatoes and corn alone of over $\$ 7,000,000$.

142 The Canning Trade, June 4, I9I7, p. Io.

143 Ibid., p. 22. 


\section{CONTROL OF THE UNLICENSED RETAILER.}

The Food Administration labored under a distinct handicap when it had to face the clause in the Food Control Act that specifically exempted retailers from license control when their gross sales fell below $\$ 100,000$ annually. This exemption embraced more than 95 per cent of the retailers in the United States, thus allowing the largest channel of distribution to go uncontrolled. Maximum margins for wholesalers, jobbers and commission merchants would be of little benefit to the consumer if retailers were free to charge what prices they wished. The exemption itself might even be taken as an encouragement of high prices. In the general scramble for profits, and with prices advancing from day to day there was a strong temptation for the retailer to take all the profit he could get. The example of the unscrupulous dealer would be apt to exercise a harmful influence upon the whole system of regulations, were he not subject to some punishments.

Since the law had specifically exempted retailers whose gross sales were less than $\$ 100,000$ a year, and since it was doubtful whether this class could be included under section 4 of the Food Control Act which forbade unjust and unreasonable charges, combinations or conspiracies to restrict supplies in order to enhance prices, the Food Administration was forced to devise some indirect means of enforcing its regulations. The method adapted was to control the retailer through the licensed wholesaler, and to exert pressure upon retail prices by consumer's reports, and the publication of "fair price" lists.

The retailer must necessarily purchase the bulk of his supplies through the wholesaler. As licenses were granted to and withdrawn from the latter upon the ful- 
fillment or infraction of specific regulations, it was felt that regulations might also be enforced whereby the wholesaler could control the retailer. The result of this belief led to the making of Rule 17, of the General License Regulations. This rule reads: The Licensee shall not knowingly sell any food commodities to any person engaged in the business of selling such commodity, who shall after this regulation goes into effect, violate the provision of the Act of Congress approved August 10, 1917 , by making any unreasonable rate or charge in selling or otherwise handling or dealing in such commodity, or by holding, contracting for, or arranging for a quantity thereof in excess of the reasonable requirements of his business for use or sale by him for a reasonable time. ${ }^{144}$

Under section 4 of the Act retailers, were prohibited from holding goods in excess of their reasonable requirements and from charging unreasonable rates. But until it was determined what reasonable rates and reasonable requirements were, the retailer was left to his own interpretation of these clauses. It was evident that before any control could be exercised over the retailer, some authoritative declarations must be made as had been done for the wholesaler. The retailer must know how much profit he could take and what charges he could make without being considered a profiteer. The spirit of the law was not a sufficient guide. Likewise he must know what constituted hoarding. The Food Administration found it necessary to fix maximum margins for all classes of goods handled by the retailer, and also to declare the quantity of goods he could hold.

Sugar and flour was limited to not more than a thirty days supply, other food stuffs to not more than $a^{\wedge} 60$ days supply. Retailers were not to sell to persons living within a city more than an eighth of a barrel of flour at a time, nor more than a quarter of a barrel to persons residing in farming communities; and not more than 2 to

I44 Cf. Sec. 4. The Food \& Fuel Control Act (Public. No. 4I, 65th Cong.) 
5 pounds of sugar should be sold to persons in a city, or more than 6 to 10 pounds to those in a farming community. ${ }^{145}$

These regulations, the Food Administration thought, should be supported by a generous spirit of co-operation. Retailers should not be made to feel these few restrictions irksome, and must be prepared for others that might be necessary in the future. Accordingly, on October 17, 1917, a representative body of retail food distributors were invited to meet at Washington. In a series of resolutions they announced their purposes of co-operation in every way possible..$^{146}$ Copies of these resolutions were printed and sent to all jobbers who distributed them to retailers. Over 3,000,000 copies were requested for distribution, so that virtually every retailer in the country was acquainted with these resolutions and knew what was expected of him.

An effective means of checking the tendency to charge excessive prices on the part of the retailer was found in the confidential weekly reports of retail prices by consumers. Early in October 1918, and continuing each week throughout the war, price blanks were sent out by the comptroller of the currency, to the banks of the country, with a request for the retail prices on several or all of the 28 commodities enumerated. Wheat flour; wheat bread, cornmeal, rice, round steak, bacon, ham, pork chops, lard, milk, butter, oleomargarine, cheese, eggs, sugar, potatoes, beans, "navy, onions, prunes, tomatoes, peas, corn, salmon, fish, hens, tea, coffee. The blanks were distributed to selected women in the town usually, such as the wives of ministers, bankers and professional men. The prices paid at grocery and provision stores were then listed, without the knowledge of the retailer. "The first weekly reports in the week of October 6, 1917, were received from 839 reporters representing 789 towns and cities. On September 28, 1918, the work has so in-

145 War Industries Bull., No. 3, Government Control Over Prices, pp. 135-6.

146 Cf. A. N. Merrit, War Time Control of Distribution of Foods, pp. $44-52$. 
creased that reports were received from 1,871 reporters representing 1,035 towns and cities." ${ }_{1,47}$

By means of these weekly price reports the Food Administration found a fairly accurate indicator of the retailers cooperation. Price curves for each of the principal cities were made, and the fluctuations in these curves were noted from week to week. Where extraordinary rises occured, an investigation was made to find the cause. In this way many attempts at profiteering were checked.

In many of the large cities throughout the country, "Fair Price Boards" were in operation. The object of these boards was not to find out the prices "actually paid" by the consumer, but to announce the prices that should be paid. Fair Price Committees were usually composed of several boards, each of which dealt with a specific group of commodities. In many cases these boards were composed of representatives of the trade, of consumers and of the Food Administration. The usual procedure was to find out the cost of each commodity to the retailer then add to this, a margin sufficient to cover expenses and a fair profit. Among the various trades there is a recognized percentage over the cost price which provides for average costs of doing business and leaves a fair margin of profit. This seems to be true of many classes of retail business. Thus, the grocer does business on a 10 per cent over cost basis; the butcher, on a $331 / 3$ per cent over cost basis. After having found out the cost price and average over-head charge and profit, it was easy to arrive at a "fair price." "Fair Prices" were not determined so rigidly as not to allow for differences in costs and service. On the contrary, they were merely prima facie results of what under ordinary circumstances would be considered reasonable. Lists of those "fair prices" were given to retailers who were asked to display them in their stores; each week the list of prices was published in the local newspapers. Although these

I47 War Industries Bulletin, Government Control Over Prices, p. 137 . 
lists of prices were not taken as final, yet as applied to any given case the individual retailer was compelled to show by the burden of proof that any price which he charged was reasonable. As few dealers wished to do this, the "fair prices" were usually adhered to.

It must not be supposed, however, that these committees loosely organized as they were and many of whose members knew little about conducting business were entirely successful. Too much dependence was placed upon the information of the retailer in these Committees. Their knowledge of costs and prices gave them an unopposed advantage in determining what the fair price should be. Another drawback in these "Fair Price Committees" was their unwillingness to resort to judicial power. Infractions of regulations were handled by the Administration at Washington. In the course of time, these became too numerous for immediate settlement. Rather than wait for the long processes of justice, these "fair price boards" preferred to dismiss the recalcitrant with a warning.

When, however, alleged violations came to the knowledge of the Federal State Food Administrator, he reported the case to the Enforcement Division at Washington. A hearing was then granted to determine whether there had been a violation or not, and if so, what fine should be imposed. After a decision was reached, an order was signed by the Food Administration and forwarded to the State Administrator who served it upon the guilty party. Orders thus served either revoked or suspended the dealers license, or imposed a fine in the form of a contribution to the Red Cross. Orders intended for a nonlicensee were usually directed to the licensee who supplied him with goods. The licensee was ordered not to supply his customer with goods till further notice. 


\section{CONCLUSION.}

In reviewing the work of the Food Administration in the attempt to pass judgment upon its policies and organization, we must bear in mind the economic conditions preceding its origin and the law from which it took its rise. These subjects have been considered in Chapters II and III respectively. It is necessary here only to call attention to the fact that the Food Administration received its authority to organize and function from the Food Control Act, and that its powers were no greater than the act allowed for. Limitations and defects such as were sure to be found in any law upon so complex a problem, will naturally find their reflection in the organization which the law brought forth.

We do not imply, however, that the Food Control Act was weak and incapable of producing an efficient system of government control. On the contrary, its powers were quite extensive and fitted for an adequate attainment of its purpose. We may complain that its purpose was poorly conceived, that it exempted producers and retailers, that it made no provision for maximum and minimum prices other than for wheat, that it contained no prohibition against the hoarding of soil products, and that finally it was designed more as a power in reserve than for any practical purpose. There is truth in the complaint but not the whole truth. The act was designed to curb profiteering and speculation. These mysterious phantoms appeared only after the product had left the hands of producers and disappeared before it reached the shops of retailers. Meanwhile the product had received successive increases in value. The profiteer was a hunted animal. People cried for his capture and the law must be laid to trap him. As for producers, the need for their products was to great, to hamper them. With these objectives not too clearly in mind, Congress framed 
a law of wide powers and left their definition to be worked out later as circumstances required.

In the beginning of the Food Administration's career, the powers it possessed were only dimly seen. Threats of more drastic enforcements were occasionally made by the Food Administrator, but it is doubtful whether he believed he had the legal power of enforcing them. The license system was generally in operation by December 1 , 1917 and it was thought that this, with the generously proclaimed offer of cooperation on the part of business men, would be sufficient. We can hardly expect to find resort to all the powers contained in the law by men who were suddenly withdrawn from executive positions in business life. These men-the associates of Mr. Hoover -would naturally advocate as little government interference as necessary. Their opposition to anything that would materially alter the practices of business and possibly lead to serious after war tendencies would be pronounced. The Food Administration, then, was unwilling to make use of all its powers at the outset.

Since the aim of the Food Administration was to interfere with business as little as possible and to exert its influence here and there to stimulate production and to check excessive prices we can not expect an elaborate and carefully planned out system of rules and regulations covering the entire field of industry. Mr. Hoover stated that "these interventions hardly ever work with complete success," that "they are the lesser of two evils, the other extreme of the dilemma is the high cost of living, constant vacillations of the wage scale and the difficulties that the country is plunged into by the rise of wages and the consequent inequalities that result from such rises."148

An outgrowth of the circumstances that gave it rise, the Food Administration's policy was simple and pliable. ${ }^{149}$ A complicated machine would have been ill-

I48 Senate Committee of Investigation on Shortage of Sugar. Dec. I9I7, p. 582 .

I49 Taussig, F., Price-Fixing as seen by a Price-Fixer. Quar. J. of Ec., Feb. I9I9, p. 206. 
fitted to meet the constant changes that were everywhere taking place in the economic and industrial world. Some form of organization whose policies could be rapidly adapted to fluctuating conditions, and whose spirit and policies harmonized with those of the people was the need of the hour. Consequently little attempt was made to lay down hard and fast principles or to provide before it was needed an extensive organization. As problems appeared, they were attacked; and both organization and principles took form as the circumstances multiplied from which they had risen.

The keystone principle of the Food Administration was the firm belief of its leaders in the efficacy of voluntary cooperation. From producer to consumer, each individual was made to feel that his or her efforts were needed to help win the war. This sense of engendered responsibility was constantly sought and emphasized in a variety of ways by $\mathrm{Mr}$. Hoover and his associates. It was "a matter of prevention, not cure."150 Much more might be expected from the policy of voluntary cooperation than from the exercise of any legal powers. It was altogether a sound psychological procedure to surcharge the people with patriotism and then to reap its effects in good will and hearty effort.

Obviously it would be impossible to expect all producers and distributors to act from patriotic motives, and sufficient evidence was had before the Food Control Act was framed, to make necessary the grave penalties which it contained. "The Food Bill has drastic powers, on the subject of extortion and profiteering, but the determination of what profiteering is, is rather difficult until after a period has elapsed, that is until after the crime has been committed." "1,51

Since the Act contained no definition of what constituted profiteeering and the Food Administration at this time had not ventured to add any light upon the subject, the determination in the first instance of whether an in- 
dividual was taking a fair and a reasonable profit was left to the conscience of each. What is a fair and reas-7 onable profit? The risks of business enterprises are so great that the determination of a fair and reasonable profit could not be made for all in the same trade. The risks of each enterpriser are different and depend upon numberless circumstances over which often the enterpriser has no control and little anticipation. Every variation in price, in demand and supply, in wages and in competition tends to produce a variation in profits. Some years a business man may receive no profits or may operate at a loss. Another year, he may gain great sums. Shall we say that the profit of a successful year is unreasonable and unfair, or shall we consider profits as extending over a period of several years. Again, what extra profit shall we allow to superior business ability? Shall we determine profits upon the average business incomes and put a penalty upon exceptional ability?

In view of the many difficulties surrounding this vexing problem of fair and reasonable profits we are not surprised to find that the Food Administration did not attempt its solution until it became urgent to do so.

The Food Control Act laid down the principles that producers and distributors should not exact more than a reasonable profit for their services. The word "reasonable" was not defined in the Act and moreover had never before received any proper legal interpretation by any governmental administrative body. "Up to this time no adequate inquiry has been found upon this subject; its discussion has been solely by law taken for granted."152 As was to be expected such lack of definition was the source of doubt and fear in the minds of those who were subject to the law, and tended to restrict unjustly and without purpose their conduct in the pursuit of ordinary business transactions.

This serious defect in the law, the Food Administration attempted to supply, by defining what it considered as "reasonable." Though it must be remembered that

152 Does Price Fixing Destroy Liberty? Geo. H. Earle, p. 38. 
when the act was drawn up, the Food Administration was not in existence, and legislators apparantly gave little thought as to how or by whom the powers contained in the Act would be exercised.

President Wilson, in Section I, "was authorized to make such regulations and to issue such orders as are essential effectively to carry out the provisions of this act." The President does not appear to have defined what reasonable profits were, more than his statement that any profits in excess of prewar profits would be construed as unreasonable. Following out this idea, the Food Administration decided that as applied to licensed "non-perishables" "reasonable profits in war time should not exceed the profits which had been made on an average by the same merchant in prewar times on an even market under freely competitive conditions." ${ }_{153}$ The average of the three years preceding the European War was taken as a basis.

Such a definition still left the interpretation of the word "reasonable" shrouded in obscurity. Profits of different trades not only varied greatly, but wide differences in profits were found even for those engaged in the same trade. To ascertain whether any dealer was guilty of taking excessive profits would require an investigation of his books. The ease too, with which profits on paper might be changed, would render such investigations uncertain. This interpretation furthermore, seemed to overlook the fact that some dealers had not been in business during the three years preceding the war, or otherwise seemed to imply that new enterprisers should be subject to the same conditions as far as profits were concerned, as others in the same line of business similarly placed.

The intention of the Food Administration seemed to be to eliminate speculative profits. The words "on an even market" as applied to prewar profits were designed to rule out profits that had been taken during this period

I53 Merritt, A. N., Wartime Control of Distribution of Food, p. 98 . 
from the sale of goods on a rising market. The problem here presented to the mind of the already perplexed business man was one that could be solved only after the advice of an expert on market fluctuations, and possibly not even then. Market conditions are in a constant state of flux, and it is upon correct estimation of these changes that profits accrue. At this point, it can be seen how undecided was the policy of the Food Administration. Its attention seemed directed to the fixing of profits rather than to the fixing of prices. Instinctively it seemed to fear the task of fixing prices, and perhaps recognized the futility of attempting to do so. Yet this task so odious to itself was shouldered upon business men under the peril of indictment.

Definite limitations on profit were early announced for manufacturers and distributors of sugar and flour. These margins were agreed to by both trades. Provisions were made later to provide for the increased costs of doing business. The dealer was permitted to take his prewar percentage of profit as a basis for present profit. Thus, "if he made 10 per cent on an article before the war, he might make 10 per cent on the same article now." ${ }^{154}$ As the prices on all commodities had increased this percentage in actual money would be much greater than previous to the war. It was permitted however, with a view to providing for increased costs, and as a stimulus to production.

The same objection held for this ruling as for the interpretation of pre-war profits. The dealer still found the decision of what profit he might take left to himself. Dishonest dealers might increase their percentage of profit without fear of detection, unless as happened in some cases where the profits exacted were so exorbitant as to clearly indicate profiteering. It was necessary, therefore to devise some method of regulating profits that could not be as easily evaded, and at the same time would place competing dealers upon a more just basis.

I54 Merritt, A. N., Wartime Control of Distribution of Foods, p. 100. 
The outcome of this conviction was the establishment by the Food Administration of definite maximum margins for each item. The problem then confronting the Food Administration was whether these margins should be fixed for each producer with reference to his costs of production or whether the same margin should be applied to all. Owing to the wide range of costs in every industry and among producers of the same commodity and the difficulty of obtaining a true knowledge of these costs all attempts to establish proper maximums for each producer had to be abandoned. Differences in costs arising from advantages of fertility, location or superior efficiency bring to their possessors a differential or rent which is appropriated as profits, and ordinarily does not result in lower prices. ${ }^{155}$ The price is the same for all wheat of the same grade, and must be high enough to induce the continued production of the high cost producers.

After much careful investigation and study into the wholesale and retail business, the Food Administration announced maximum margins for wholesalers, which were followed later by maximum margins for retailers. These margins whether expressed in cents or per cents generally provided a profit sufficient for the high cost producers, and a lesser profit for the producer whose costs were not so high. In conjunction with these margins, the prewar profit rule was still in effect, which could be used against a dealer whose profits were high and who sought to protect himself under the maximum margin.

The fixing of a "reasonable" price when the supply of a commodity is below normal does not however solve the difficulty. If the price is fixed lower than the ordinary competitive price, hoarding and increasing consumption follow, and the poor are unable to get the necessaries of life. Unless some system of rationing and of priority of

I55 Economic Difficulties in the way of successful Governmental price-fixing. The Economic World, July 21, 1917, p. 97. 
distribution is used in conjuction with price fixing, the latter will be a failure.

Government control over prices when once begun tends to increase and evasions on the part of those subject to control only intensify the efforts of those in authority to enforce regulations with the result that production is curtailed, healthful competition is ruined and initative crushed. The cost of installing such an elaborate system of supervision is enormous, and must be met sooner or later by those for whose benefit it was designed.

One complaint against the Food Administration was that it brought men into its fold from the very businesses and industries they were to regulate. It was impossible, that these men controlling large interests in their particular line of business should become so altruistic as to forget their private interests in the endeavor to offer patriotic service. The opportunities at hand to spread propaganda, to take advantage of private information of large government orders, and of market conditions were too great not to be made use of. Not only could they bring grist to their own mills but also to those of their trade. The Food Administrator was even accused of appointing as heads of divisions men whom he knew would use their information for selfish purposes. Whether or not this be true we have no means of ascertaining. It may be said in defense of utilizing men who were expert in their line of business that their knowledge was extremely necessary for the handling of many of the problems confronting the Administration. The complexities of market conditions alone would warrant their employment.

Whether the Food Administration did a wise thing by not compensating these men it is hard to say. While bound to give a more disinterested service, it is doubtful whether they would be inclined to leave their positions for salaried government service. The government could not compensate them upon the basis of their previous earning capacity, and a monetary return would reduce the glory of volunteer service. The real excuse for not 
paying these men, must doubtless be found in the enormous cost.

From the fore-going pages, it will appear that the. United States Food Administration received wide but somewhat undefined powers from the Lever Food Control Act. The chief policies of the Food Administration-its dependence upon voluntary coöperation and the license system-were provided for in the Act, and remained only to be put in operation. The problem of what constituted just and reasonable profits was left undefined in the Act. This, the Food Administration partly solved by declaring maximum margins for wholesalers and retailers. The lack of legal definition seems to have been over-exaggerated by the Food Administration. Frequently this lack was made the plea for inaction. As an organization, the Food Administration was extensive, but loosely constructed. It showed itself fairly well adapted, however, to meet the ever-changing conditions of the time. It possessed the advantage of being able to recruit many of the country's best business and scientific men and place them in positions of leadership. The organization was practical and efficient, and despite the defects mentioned, was a credit to our war-time achievements.

In the pages following will be found a brief account of early attempts at price-fixing. 


\section{APPENDIX.}

\section{EARLY ATTEMPTS AT PRICE-FIXING.}

Examples of government control over prices are almost as old as organized society itself. One of the first attempts recorded is that of the State of Athens three centuries before the advent of Christianity. The Athenian statesman sought, first of all to make provision for an adequate supply of grain, for the Athenians consumed more than they produced. Much grain had to be imported from Pontius, Geraestos and other places. Boech $^{156}$ estimates that the Athenians imported one third of the total amount needed for consumption; while Botsford $^{157}$ places the amount at one half. Cornering the grain market was attempted by speculators in Athens in those days and stringent regulations were laid down by the State to check their activities. No one was allowed to buy more than fifty phormi at a time, ${ }^{158}$ and the profit on a basket could not be more than an obol.* Despite these laws, however, dealers often bought up all the grain they could to sell it the same day for a higher price. ${ }^{159}$ The State, in order to remedy these evils appointed a body of officers whose duty it was to investigate and regulate the supply and the prices of grain. They were also charged with the inspection of bread and meal, that these might be sold according to the legal weight and price. Storehouses were erected for grain from which the people could purchase at reasonable prices, and in some cases receive grain gratuitously. Notwithstanding the severe penalty of death incurred by the offenders

156 Boech, A., The Public Economy of the Athenians, p. II4.

157 Botsford, E. W. \& E. G. Sihler, Hellenic Civilization, p. 426.

158 Botsford, Opus Cit., p. 426.

* An obol was equal to one sixth of a drachma, whose value varied from 9 to 17 cents.

159 Cf. Works of Lysias, XXII (against the grain dealers). 
of these regulations, it appears that violations were frequent. ${ }^{160}$

Among the early examples of price-fixing in the Roman Empire is that of the Emperor Dioclitian. who in $301 \mathrm{~A}$. D. attempted to check prices and perhaps also to impose his will upon the people for the sake of the pleasure it afforded him. Dioclitian fixed prices for all commodities and also for wages. A list of some of the prices so fixed may be found in Palgraves' "Dictionary of Political Economy."161. The severe penalties of deportation and death attended the violation of this edict. yet it does not seem to have been obeyed. Whatever good the edict could have effected was more than offset by the vexatious strictures it placed upon freedom of production and importation.

Sixty years later the Emperor Julian tried the same experiment with similiar results. An account of both attempts is found in Abbot's "The Common People of Ancient Rome."

"When he (The Emperor Dioclitian) had brought on a state of exceeding high prices by his different acts of injustice, he tried to fix by law the prices of articles offered for sale. Thereupon for the veriest trifles much blood was shed. and out of fear nothing was offered for sale and scarcity grew much worse. until, after the death of many persons. the law was repealed from mere necessity."

"The Emperor Julian sixty years later fixed the price of wheat for the people of Antioch by an edict. The holders of grain hoarded their stock. The emperor brought supplies of it into the city. from Egypt and elsewhere, and sold it at the legal price. It was bought up by speculators. and in the end, Julian like Dioclitian had to acknowledge his inability to cope with an economic law."*1,62

ı6o Cf. Works of Lysias, XXII.

I6I Palgrave, Dictionary of Political Economy, cf.: "Justum Pretium."

I62 Abbott, The Common People of Ancient Rome, p. 274.

* The law of supply and demand, according to economic theory, is a basis factor in determining prices. 
The Just Price of the Medieval Economists.

There is, perhaps, no medieval theory in economics which has received greater attention from modern writers than the teaching of the just price. The doctrine of the just price was set forth in all the manuals in theology during the Middle Ages, for economics was not then as it is now, a special science. In the 'Summa' of St. Thomas the doctrine of the just price is treated as a particular case under the general caption of 'contract of sale' $\mathrm{He}$ states the argument from justice in regard to prices as follows: "Apart from fraud, we may speak of buying and selling in two ways. First, as considered in themselves and from this point of view buying and selling seem to be established for the common advantage of both parties. one of whom requires that which belongs to the other and vice-versa. Now, whatever is established for the common advantage should not be more of a burden to one part than to another, and consequently all contracts between them should observe equality of thing and thing. Again, the quality of a thing that comes into human use is measured by the price given for it, for which purpose money was invented. Therefore, if either the price exceed the quantity of the thing's worth, or conversely the worth of the thing exceed the price, there is no longer the equality of justice; and consequently to sell a thing for more than its worth, or to buy it for less than its worth, is in itself unjust and unlawful." This teaching was repeated and emphasized by nearly all the succeeding theologians and canonists in the Middle Ages. Thus Biel writes; "Si pretium excedit quantitatem valoris rei, vel e converso tolleratur equalitas, erit contractus iniquus." 163

The idea of a just price is essentially Christian. Roman Law allowed great freedom of contract in sales. Buyers and sellers were left to their own shrewdness or folly and assumed risks accordingly. Only in the case of manifest fraud was the seller protected by law. It is

I63 Repertorium generale inventarium super quator libros sententiarum, IV, XV, ro. "If the price exceeds the value of the thing or conversely destroys equality, the contract is unjust." 
stated that if the seller received only half of the value of the thing, the contract could be voided, unless the buyer restored the other half. Neither St. Thomas nor St. Augustine have answered the question that has long vexed the minds of economists: How do we arrive at the just price? What are its determinants? St. Thomas has not recorded this vital piece of information, not however, because it did not occur to him nor because it presented difficulties hard to solve, but because he took it for granted that the traders of the day were familiar with the mechanism of the just price. The writings of the canonists supply this omission. Incidentally it may be mentioned here that all theologians and canonists were in agreement in recognizing the power of the state to fix prices. Gerson states that: The law may justly fix the price of things which are sold, both movable and immovable,-As price is a kind of a measure of the equality to be observed in contracts, and as it is sometimes difficult to find that measure on account of the varied and corrupt desires of men, it becomes expedient that the medium should be fixed according to the judgment of some wise man-In the civil state, however, no one is to be decreed wiser than the law-giving authority, therefore, it behooves the latter, whenever it is possible to do so, to fix the just price, which may not be exceeded by private consent, and which must be enforced. ${ }^{164}$

Langenstein in his famous work on Contracts lays down the rules that should guide a prince in the fixing of a just price. Circumstances of time, and of place and the conditions of the people should be considered. Again, the commodity is to be measured with the intensity of the desires for it. Some commodities are necessary by nature, as flour, salt, etc.; others are relatively necessary, as those needed to sustain one's state in life, for example, cloth of a certain texture for one's garments. Other commodities are sought for pleasure or distinction (luxuries). The general rule is that the prince must seek to find a medium between a price so low as to render labor-

I64 De Contractibus I, I9. 
ers, artisans, and merchants unable to maintain themselves suitably and one so high as to prevent the poor from obtaining the necessities of life. In the article in the Catholic Encyclopedia under Political Economy, the writer places as a basis of the just price a living wage: the just price of an article included enough to pay fair wages to the worker-that is, enough to enable him to maintain the standard of living of his class.

Ideas of justice vary with individuals and much of the misconception surrounding the just price teaching is due to the fact that each interpreter injects his own meaning of justice into the technical concept of price. The point to be emphasized here is that justice was considered an objective thing, and the living embodiment of justice was the civil authority. Consequently, when that authority or any body of men or committee delegated by it fixed a price as just, using all the ordinary standards of judgment, that price ipso facto was held as just. The guild masters or who ever fixed prices were not free, of course, to use any arbitrary methods in determining it. The just price must be based on the natural price, which was the price that would tend to be fixed in a free market. Any change in the scarcity or demand, or the cost of production would produce a change in the natural price and thus necessitate a revision in the just price. ${ }^{165}$

Prices were not always fixed by law during the Middle Ages. Where the law did not decide the price, the matter was left to buyers and sellers, who based their estimation of the value of the thing as accurately as the principles of justice would allow. The price arrived at from the 'communis estimatio' was known as the natural or common price. Much discussion has been given to the meaning of 'communis estimatio,' some attempting to show that it is the same as 'social valuation' as found in modern theories of value. The natural price, thus based on something not capable of accurate measure could not, as we may reasonably expect, be worked out with mathe-

I65 G. O'Brien, An Essay on Medieval Economic Teaching, p. 107. 


\section{Appendix-Early Attempts at Price-Fixing.}

matical precision. Nevertheless, the theologians laid down rules that fixed the common price within fairly definite bounds when they recognized the three-fold division of price-the highest, the lowest and the medium. Any price exceeding the highest, or below the lowest was unjust. It should be noted that the just price of the medieval theologians was not a fixed price. Between the highest and the lowest margins there was a considerable space through which it might travel with perfect ethical freedom. A price could be termed just theoretically when it received authoritative promulgation the same as a law. Practically, however, it would be a travesty to define any price as just which manifestly disregarded the economic forces which determine prices; namely, supply and demand. These forces operated just as potently in guild times as they do to-day. Added to these two price determinants was a third, which doubtless, had considerable influence namely, custom. Many of our price fluctuations, it must be remembered, are due to changes in the volume of money. Since the production of metals was slow, and commerce between nations was undeveloped, the supply of money media in the Middle Ages tended to remain unchanged and hence, this disturbing influence upon prices was not felt. Supply and demand, moreover, restricted to small areas, with little expansion of wants and few substitutes for these wants, could be measured quite accurately. Prices changes, therefore were not frequent, and after the lapse of years, custom became arbiter in keeping prices stable. Any price that notably exceeded the customary price without a manifest cause was quite naturally stamped as unjust. In our complex economic organism, this factor of custom as a price stabilizer has largely lost its influence. Because prices fluctuate more often and with greater swings today, we cannot therefore assume that our prices are less just than those of the Middle Ages. While our system is more complex, it is at the same time more sensitive, and in nothing is this sensitiveness more clearly seen than in price changes. 
We now come to another example of price-fixing. In the archives of the University of Oxford are preserved volumes containing the accounts of the clerks of the market, from the years 1645 to 1658 inclusive. These accounts exhibit the prices and the quantities of wheat (corn) sold, together with the names of the buyers for each market day during the above-named years. In addition to the price of wheat (corn), the prices of malt, barley, beans, oats and peas are given. ${ }^{168}$ A Board of Commissioners was authorized to examine the weights and measures, and to fix the weight of bread according to the market price, and on some occasions to fix both the weight and the price.

"First they shall inquire the price of wheat, that is to wit, how' a quarter of the best wheat was sold the last market day and how the second, the third and how a quarter of barley and oats."

"After, upon how much increase or decrease in the price of wheat a baker ought to charge the assize and weight of his bread."

"Also, how much the wastel of a farthing ought to weigh, and all other manner of bread, after the pense of a quarter of wheat they present."

"And for default in the weight of bread, a baker ought to be amerced or to be judged into the pillory according to the law and the custom of the court."167

In these records are found the original orders for fixing the weight of bread, and the changes as required by the market fluctuations of wheat and other commodities. The weight of the loaf was ordinarily adjusted to the market price, but occasionally the market price was set aside for one fixed by the Commissioners. On the 9th of September, 1647, for example, the market price of corn was 49s. 4d. the quarter; the Commissioners on that same day "agreed the price to be $47 \mathrm{~s}$, the quarter." The

166 Lloyd, W. F., Prices of Corn in Oxford (Pub. MDCCCXXX), London, p. 2.

167 Ibid., p. 4. 
price of beer was fixed by the price of malt as appears from the following record:

"Malt being at $17 \mathrm{~s}$. $4 \mathrm{~d}$. the quarter, the barrel of double beer is to be at $8 \mathrm{~s} .8 \mathrm{~d}$. and the middle and single beer proportionable," Viz:

"Double beer ...........8s. 8d.

"Middle beer ...........6. 6d.

"Single beer ............4s. 4d.

and the ale at 4 s. $8 \mathrm{~d}$. the quarter."

A proclamation issued in 1545 concerning corn and grain empowered the commission to search houses and barns for hidden supplies and sell them in the market and also to fix the prices of these commodities when they shall judge such to be necessary. It states that certain subjects "who having more respect to their own private lucre and advantage than to the common weal of this his Highness's realm, have by diverse and sundry means accumulated and got into their possession a great number and multitude of corn and grain-and do wilfully detain and keep in their possession-intending thereby for to cause the prices of corn to rise, so that they may sell their corn and grain at such unreasonable prices as they will..."."168 This proclamation orders the justices of the peace to search houses and barns and yards of all persons accustomed to sell corn or gain and to bring or to cause to be brought the surplus to the market.

Such interference on the part of the government today would constitute a direct assault upon our cherished principle of economic freedom. Business enterprise would lack the attraction of unregulated profits. Fear of punishment would stifle initative. Yet viewing the conditions in which this system operated, we can easily see the need of some such supervision. In the above-mentioned period, supply and demand was necessarily local. This condition would enable individuals to monopolize a commodity for several days with well-nigh complete success. Markets were scattered, communication was slow,

168 A. E. Bland \& Others, "English Economic History," pp. $367-8$. 
and substitutes were few. There were no powerful combinations of capital to impede regulatory measures in favor of the consumer. Conditions, therefore, fostered government supervision and made it effective.

Price-Fixing During the French Revolution.

Another attempt to fix prices was made during the French Revolution. Owing to the blockage of the British fleet importation of foodstuffs was at an end. Added to this was the shortage caused by a succession of bad crops. These factors, however were insignificant in bringing about high prices and hardships when compared to the over issues of paper money by the government. Hard pressed for money to finance her military operations, the government resorted to the temporary expediency of frequent issues of paper money. With each issue the prices of commodities increased. Soon the value of paper money so depreciated that people were unwilling to take it in exchange for commodities or services. This hindered the circulation of goods to a great extent, for the poor had no money to pay for goods than the almost worthless paper.

Measures were taken by the City of Paris and other cities to check the constant rise in prices. First. an attempt was made to get control of the grain supplies, in order to sell flour to bakers at reduced prices. "Flour," wrote Roland to the Administration of Paris, "comes to 62 livres a sack, and to keep down the price of bread it has been sold to bakers at 54 livres, a daily loss of 12,000 livres." 169

On April 16, 1793, the administration of Paris addressed a petition to the Convention demanding that maximum prices for grain be fixed. After much debate the Convention decided to fix the maximum price for all grains. The purpose of this regulation was to eliminate as far as possible the middleman's profit. It soon became evident, both to the people and to the Commission that other commodities besides grain would have to be controlled. Thus maximum prices were fixed for all 
primary and secondary necessities. Moreover, the Commission also decreed that the maximum or highest figure respectively of salaries, wages and piece-work by the day, shall be fixed up to the September following by the General Councils of the Commune at the same rate as in 1790 , with half that sum in addition.... Prices up to this time had been fixed upon the basis of those prevailing in 1790 plus 33 and one third per cent. This broad and indiscriminate method of determining prices worked to "injure the small trades, and to profit the greater ones." To fix a just price injurious to no one, it was thought necessary to know the "value of each on production," to which should be added a five per cent profit for retailers and a five per cent profit for wholesalers. A gigantic inquiry was begun forthwith, to establish the cost of production for primary and secondary necessities. This inquiry was never finished, for price-fixing was soon seen to be productive of greater evils than it attempted to remedy.

A fixed price that is considerably lower than what could be got in the market will hardly ever be successful. In times of scarcity producers expect high profits, and cannot be prevailed upon to market their goods unless a generous profit is included in the fixed price. During the Revolution, prices were fixed too low. "As soon as we fixed the price of wheat, rye and of mixed wheat and rye we saw no more of these grains. The other kinds not subject to the maximum, were the only ones brought in. What is the inference? The establishment of a maximum brings famine in the midst of abundance. What is the remedy? Abolish the maximum."170

Price-Fixing in the United States During and After the Revolutionary War.

The economic distress left in the wake of the American Revolutionary War is known to every student of history and economics. Due to the enormous issues of paper money both by the Continental Congress and the individual states, values rapidly depreciated, and prices

I70 G. Lefebre, Documents relatifs a l'Histoire des Substances dans le District de Bergues, Vol. I, pp.347-87. 
rose to unprecedented heights. By January, 1777, a premium on coin was fixed at five per cent. As early as February of the preceding year high prices had begun to receive the attention of a Committee of Representatives. "For months thereafter petitions poured into the Assembly representing that merchants and farmers were charging exorbitant prices for their goods, and praying for legislation."171

On June 19, 1776, the Massachusetts General Assembly by resolve temporarily prohibited the transportation of provisions out of the state. ${ }^{172}$ On September 4th the prohibition was extended to lumber.

It soon became apparent that no state could deal with the problem of high prices single-handed, and that any attempt to regulate prices in one state would be futile until bordering states would agree to the same regulations. This conviction led to a Convention of Committees on December 25th, 1776, from the States of New Hampshire, Massachusetts, Rhode Island and Connecticut which met at Providence, $R$. I. for the purpose of recommending a scale of commodity prices for the several States. The Committee went into the matter and furnished a price-list which included almost every commodity for which money could then be expended in New England. The recommendations of the Committee were accepted in Massachusetts and immediately put into practice in Boston and other towns, under the Act to Prevent Monopoly and Oppression.

This Act was to remain in force for three years, but its life was less than a year. It was repealed in October 1777 to provide for an act of greater territorial area. The following month Congress divided the States into three groups and recommended Conventions for each of the three for the purpose of fixing the prices of labor and commodities. ${ }^{173}$

The States sending delegates to the New England divi-

17 Publications of the Colonial Soc. of Mass., Vol. X, p. II6.

172 Ibid., p. II7.

173 Massachusetts Province Laws, Vol. V, pp. 73-738. 
sion were New Hampshire, Connecticut, New York, Massachusetts, Rhode Island, New Jersey and Pennsylvania. The Convention was held at New Haven, Conn., and there drew up a scale of prices for the New England division. Some States refused to abide by the prices determined in this convention, others adopted them but experienced such difficulty in putting them into practice that the attempt had to be abandoned.

The citizens of Philadelphia met in the State house on May 25th, 1779 and adopted resolutions to enforce a schedule of prices drawn up by a Special Committee a few days before. ${ }^{174}$

In a report of the Committee of the Town of Bingham, Mass., 1779, the following resolutions were laid down regarding the prices of commodities: "First, resolved that from after the Tenth day of August instant the following articles of produce, Manufactures and Labor be not sold at higher prices than is hereafter affixed to them Vig W: India Rum L6-6s pr gallion. N : England Do: L4-16 Molasses L4-7. Coffee 18s pr. lb. Brown sugar from 11s to 14s pr. lb. Chocolate $24 \mathrm{~s}$ pr. lb. Bohea Tea L5 pr. lb. Cotton $36 \mathrm{~s}$ pr. lb. German Steel $36 \mathrm{~s}$ pr. lb. Salt of the best quality L9 pr. Bushel."175

Indian Corn ...LL4..10 Fresh Beef ....L 0..5..9

Rye .......6.6. 0 Mutton ........4.0

Wheat .......9 0 Veal .............

Barley ........ 2..16 Lamb ............4..0

Oats ........ 1..16 Butter .........12..0

Beans ...... 9..0 Cheese ........6.0

Potatoes ....... 1..10

Turnips ........1.10

These prices were fixed only to be disregarded. The faith these law-makers placed in statutes seemed to triumph over the fruits of experience. The fault, they thought, was not in price-fixing legislation but in the ungovernable spirit of the people. After various other at-

I74 The Colonial Society of Mass., Vol. X, p. I27.

I75 Ibid., p. II6. 
tempts to fix prices in many towns in New England, the experiment was definitely abandoned.

The results of this study show that price-fixing is an artificial arrangement which seriously disturbs the operation of economic laws and interferes with business activity; that the more directly prices are fixed less chance they have of being observed and that a of price fixing, to be successful, must be based on a close adherence to economic principles and market conditions. Direct price-fixing has usually failed because of its disregard for these principles and conditions. A system of indirect price control, such as exemplified by the United States Food Administration interfers with the economic system as little as possible. It achieves its result by asking instead of demanding. 


\section{BIBLIOGRAPHY.}

The Official Bulletin, published by the Government, and the Commercial and Financial Chronicle give espe tity comprehensive statements of the formal controls as twey were adopted. A much fuller bibliography on this subject has been prepared by the Congressional Library at Washington.

\section{BOOKS.}

Abbott, F. F. The Common People of Ancient Rome. New York. C. Scribner's Sons, 1911.

Bland, A. E. and Others. English Economic History. London, G. Bell \& Sons, 1915.

Boeckh, A. The Public Economy of the Athenians. Boston, Little, Brown \& Co., 1857.

Clark, J. B. The Problem of Monopoly. New York, The Columbia University Press, 1904.

Cunningham, Wm. The Growth of English Industry and Commerce, 5th ed., Cambridge University Press, 1910-1912, Vol. 3.

Davis, A. The Limitation of Prices in Massachusetts 1776-79. Boston, Publications of Mass. Colonial Society, Vol. 10.

Earle, G. H. Does Price-fixing Destroy Liberty? Philadelphia, 1920.

Fisher, J. Stabilizing the Dollar. New York, E. P. Dutton \& Co., 1919.

Gephart, W. F. Some Economic and Legal Aspects of Fixed Prices. Washington University Studies, Apr., 1916, Vol. 2, pt. 2.

Gray, H. L. War Time Control of Industry. New York, MacMillan, 1918.

Guyot, Yves. Where and Why Government Ownership Failed. (Tr. from the French by H. F. Baker). New York, MacMillan, 1914, pp. 175-180. 
Kellogg, V. L. Herbert Hoover, the Man and His Work. New York, D. Appleton \& Co., 1920.

Kellogg, V. L. The Food Problem. New York, Macmillan, 1917.

Laughlin, J. L. Money and Prices. Scribner's Sons, 1919.

Litman, S. Prices and Price Control in Great Britain and the United States. New York, Oxford Univ. Press, 1920.

Merritt, A. N. War Time Control of Distribution of Food. New York, Macmillan, 1920.

Meyer, E. War Profiteering, Some Practical Aspects of Its Control. Washington, D. C., 1917.

O'Brien, G. Essay on Medieval Economic History. New York, Longman's Green Co., 1920.

Philip, A. J. Rations, Rationing and Food Control. London, The Book World, 1918.

Rogers, J. E. The Economic Interpretation of History. New York, G. P. Putman's Sons, 1889.

Stull, Wm. The Food Crisis and Americanism. New York, Macmillan, 1919.

Van Hise, C. R. Conservation and Regulation in the United States during the World War. Washington, Government Printing Office, 1917.

Wallace, H. A. Agricultural Prices, Des Moines, Ia., Wallace Publ. Co., 1920.

Wilkinson, H. L. State Regulation of Prices in Australia. Melbourne, Melville \& Mullen, 1917.

Willoughby, W. F. Government Organization in War Time and After. New York, D. Appleton \& Co., 1919.

The World's Food. The Annals of the American Academy. Nov. 1917, Vol. 64.

Selected Publications of the Food Administration. Bulletin No. 1, Food Administration; No 6, Creation of United States Food Administration; Plans for wheat, flour and bread control; No. 8, Commodity licensing; No.

15, Food control a war measure; Bulletin for the clergy; Bulletins for Agricultural Speaker Service (Nos. 1 to 24) ; Fair prices October 1918, How the retailer can help 
the United States Food Administration, 1918; Plan of wheat and flour control for 1918; Press releases; Proclamations and executive orders by the President, Nov. 1918; United States Food Administration, laws and rulimp compiled by Commerce Clearing House, New Yore 18.

Publications of the War Industries Board.

A comparison of prices during the civil war and present war, 1918; Government Control over prices, Garrett, P. W. Bull. No. 3, 1920; Fluctuations of controlled and uncontrolled prices, Bull. No. 10, 1918. History of Prices during the war, Mitchell, W. S. Bull. No. 1, 1919; International Price Comparisons, Mitchell, W. S. Bull. No. 2; Official Bulletin, (from May 10, 1916 to March $31,1919)$.

\section{PERIODICALS.}

The following list of periodicals contain useful articles: American Economic Review, Quarterly Journal of Political Science; Annals of American Academy, Economic World, Commercial and Financial Chronicle; Atlantic Monthly, Outlook, American Review of Reviews.

The following articles may be consulted: Anderson, B. M. Prospect of success for government price-fixing in the United States. Econ. World, Jan. 5, 1918, N. S. Vol. 15; II ; also Value and price theory and price-fixing. American Econ. Rev., March, 1918, Vol. 8: Sup. 239-56. Ballantine, A. A. Prices according to law, Atlantic Monthly, Nov. 1915, Vol. 116; 668-77; Carver, A. B. Possibilities of price-fixing in time of peace. Amer. Ec. Rev. March, 1919, Vol. 9; Sub. 246-51; Davis, J. E. Price control, Annals of Amer. Ac.; Nov. 1917, Vol. 74: 288-93; Gephart, W. T. Provisions of the Food act made permanent, Amer. Ec. Rev. March, 1919, Vol. 9; Sup. 61-78; Gray, L. C. Price-fixing policies of the Food Administration, Ibid. 252-71; Haney, L. H. Price-Fixing in a competitive industry, Ibid., 47-56; Lubin, D. Food Control and Democracy, Atlantic Monthly, 1917, Vol. 120, 26069 ; Seligman, E. R. Government price regulation. American R. of R's, Sept. 1917, Vol. 56 : 289-92. 


\section{VITA.}

Joseph Charles Bartley was born in Lawrence, Massachusetts, May 23, 1893. He received his elementary education in the public schools and attended for two years the Lawrence High School. He entered St. Rita's Hall, Villanova, Pennsylvania, September, 1910. He received the A.B. degree in 1916, and the M.A. degree in 1919 from Villanova College. He was raised to the priesthood as a member of the Order of St. Augustine, in June 1919. The following September he entered the Catholic University of America where he followed courses in Economics under Frank O'Hara, Ph.D. and Rev. John A. Ryan, D.D., in Sociology under Rev. William J. Kerby, S.T.L. and in English under Patrick J. Lennox, Litt.D.

He is particularly indebted to Dr. Frank O'Hara, his major professor, for the valuable assistance rendered in the preparation of this dissertation. 

THIS BOOK IS DUE ON THE IAST DATE STAMPED BELOW

AN INITIAL FINE OF 25 CENTS WILL BE ASSESSED FOR FAILURE TO RETURN THIS BOOK ON THE DATE DUE. THE THE FOURTH WILL INCREASE TO 50 CENTS THE SEVENTH DAY DAY AND OVERDUE.

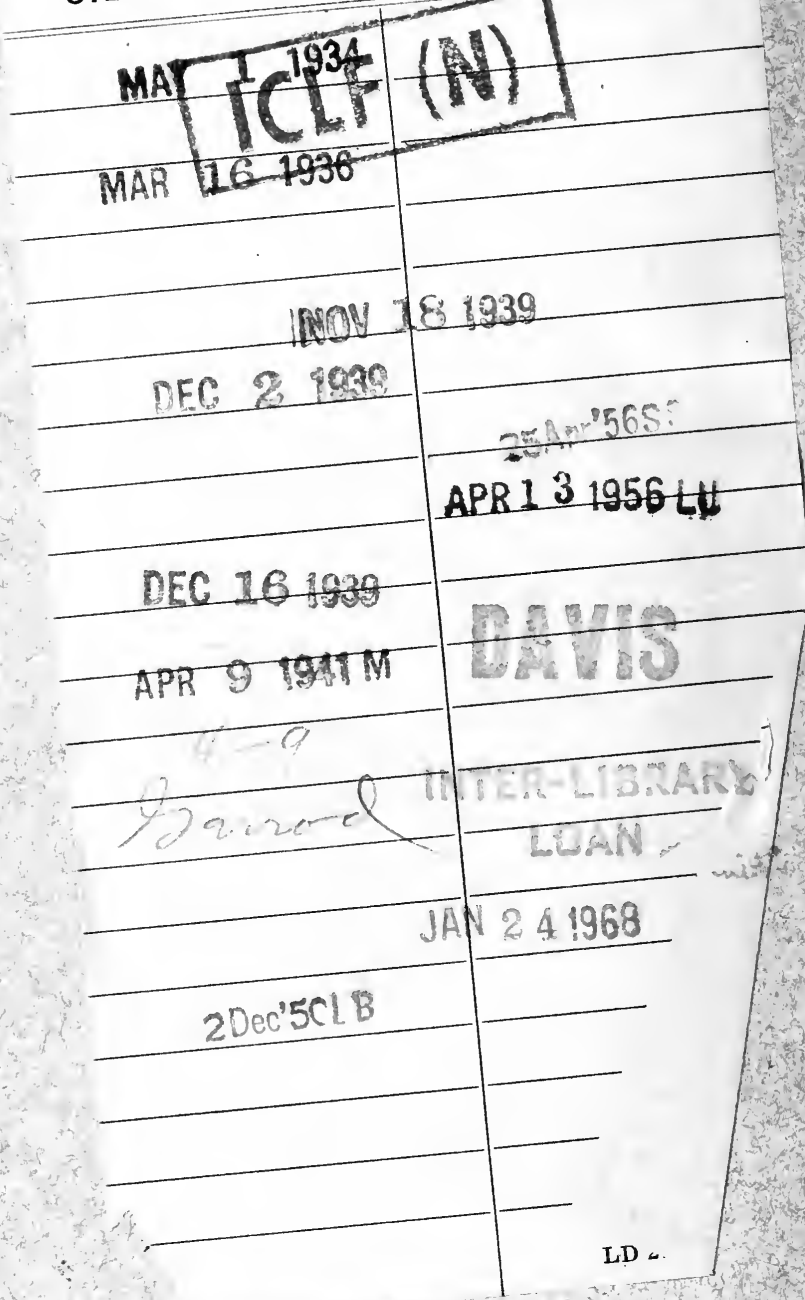


RETURN TO the circulation desk of any University of California Library

or to the

NORTHERN REGIONAL LIBRARY FACILITY Bldg. 400, Richmond Field Station University of California Richmond, CA 94804-4698

ALL BOOKS MAY BE RECALLED AFTER 7 DAYS 2-month loans may be renewed by calling (510) 642-6753

1-year loans may be recharged by bringing books to NRLF

Renewals and recharges may be made 4 days prior to due date

DUE AS STAMPED BELOW 
